RODRIGO DA SILVA LIMA

PROPOSTA DE MODELO PARA IMPLANTAÇÃO DE UM SISTEMA DE INDICADORES DE DESEMPENHO

SÃO PAULO

2010 
RODRIGO DA SILVA LIMA

\section{PROPOSTA DE MODELO PARA IMPLANTAÇÃO DE UM SISTEMA DE INDICADORES DE DESEMPENHO}

Dissertação apresentada à Escola Politécnica da Universidade de São Paulo para obtenção do título de Mestre em Engenharia 
RODRIGO DA SILVA LIMA

\section{PROPOSTA DE MODELO PARA IMPLANTAÇÃO DE UM SISTEMA DE INDICADORES DE DESEMPENHO}

Dissertação apresentada à Escola

Politécnica da Universidade de São

Paulo para obtenção do título de Mestre em Engenharia

Área de Concentração: Engenharia de Sistemas Logísticos

Orientador: Prof. Doutor Rui Carlos Botter

\section{SÃO PAULO \\ 2010}




\section{DEDICATÓRIA}

À Simone Lima, minha querida esposa, com todo meu amor, pela sua paciência, apoio e compreensão durante todo o período do mestrado. 


\section{AGRADECIMENTOS}

Ao meu Deus por mim dar forças para continuar e jamais desistir, e pela grande benção de concluir o mestrado na USP.

À minha esposa Simone e meus filhos Lucas, Ana Clara e Daniel, os quais são fundamentais para a minha motivação afim de vencer os desafios.

Ao Prof. Dr. Rui Carlos Botter, pela atenção, orientação e dedicação ao longo de todo o meu mestrado. 


\section{RESUMO}

Em menos de duas décadas, um novo mundo competitivo emergiu fazendo surgir nas organizações uma nova demanda de indicadores de desempenho. Neste ambiente, mais do nunca, é requerido aos Executivos o uso de indicadores significativamente melhores, que direcionem as estratégias e o desempenho dos negócios. Eles precisam de indicadores que vão além dos indicadores financeiros para direcionar as mudanças, mostrar a posição competitiva, aprimorar os processos e melhor prever o futuro. Este estudo procura apresentar um modelo para auxiliar as Organizações na gestão do aprimoramento de seus processos, de maneira eficaz e eficiente, através do uso de um sistema de indicadores de desempenho, partindo de sua estruturação, identificação e forma de medição, até o uso correto das informações coletadas e processadas de modo a atender às metas delineadas por uma estratégia traçada pela Organização. O objetivo principal deste trabalho é desenvolver um modelo para implantação de um sistema de indicadores. Como objetivos secundários pretendem-se: identificar os principais modelos de gestão baseados em indicadores de desempenho; dentre os modelos de gestão, levantados, adaptar um método de implantação e realizar uma aplicação rápida no departamento de logística em uma empresa de mineração. Para tanto, buscou-se um embasamento teórico a partir dos seguintes modelos de avaliação de desempenho: Gerenciamentos pelas Diretrizes (GPD), Capital Intelectual, Modelo Quantum, Rummler \& Brache, Sink \& Tutle e Balanced Scorecard (BSC); de onde se concluiu que os modelos mais adequados para a realização do trabalho seriam o GPD e o BSC, visto que, este leva em conta não apenas perspectivas financeiras para a avaliação de desempenho.

Palavras-chave: Indicadores de desempenho, Balanced Scorecard, Gerenciamento por diretrizes. 


\begin{abstract}
In less than two decades, a new competitive world has emerged and put stringent fresh performance demands on all organizations. In this environment, executives require significantly better measures to direct strategy and business performance than ever before. They need measures that go behind the financials to drive change, show competitive position, improve business processes, and better predict future. This study tries to present a model to help organizations to manage its processes improvement, in an effectiveness and efficiency way, trough the use of a performance measurement system, from the way it is structured, identified and measured, till the correct using of the data collected and processed to attend the targets defined by the organization strategy. The main target of this work is to develop a model of implementation of a management system. As secondary targets is intended to: Identify the main models of key performance indicator management based; among these studied models, choose which one is more suitable to be used and fast implementation in logistic department in a mining company. In order to do this, it was looked for theory based upon the following performance evaluation models: Policy Management (PM), Knowledge Capital, Quantum model, Rummler \& Brache, Sink \& Tuttle and Balance Scorecard (BSC); which was conclude that the more adequate model to do this work was the PM, and the BSC, since it consider other perspectives besides than just the financial perspective in order to evaluate the performance.
\end{abstract}

Key words: Key performance Indicator, Balanced Scorecard, Policy Management. 


\section{LISTA DE FIGURAS}

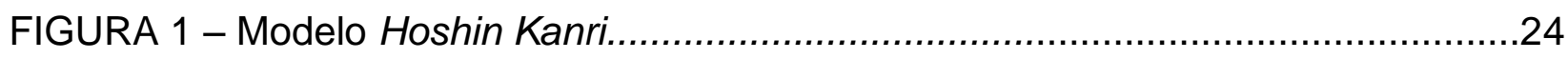

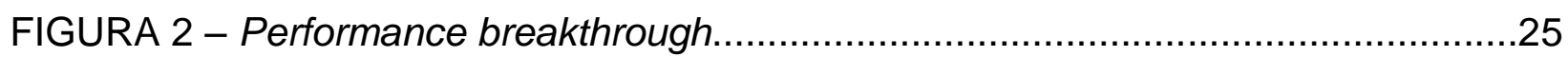

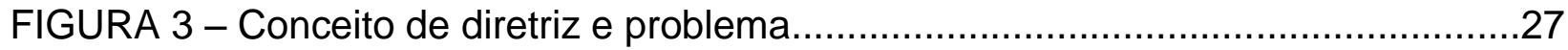

FIGURA 4 - Matriz de relações metas-meios (quadro conceitual)......................................29

FIGURA 5 - Modelo utilizado para desdobrar uma diretriz..........................................29

FIGURA 6 - Esquema Skandia para o valor de mercado através do desdobramento do

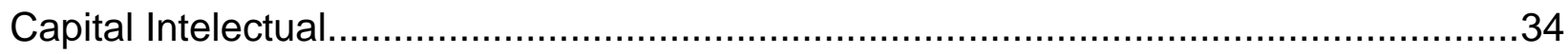

FIGURA 7 - Mapa Relacionamento das dimensões do modelo Quantum......................41

FIGURA 8 - Processo de Planejamento de Performance .........................................51

FIGURA 9 - O sistema organizacional e os sete critérios de performance.....................53

FIGURA 10 - Relacionamento entre os objetivos do BSC ........................................59

FIGURA 11 - Relacionamento dos indicadores de performance de clientes.................66

FIGURA 12 - Relacionamento dos indicadores de performance de clientes.................72

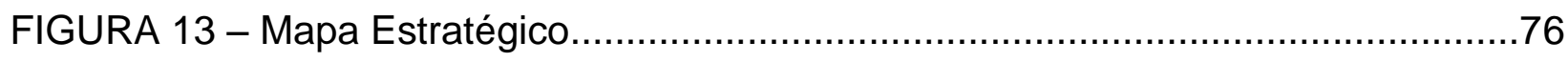

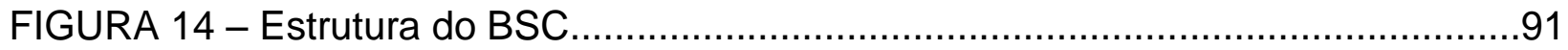

FIGURA 15 - Desdobramento das diretrizes pelo método A .......................................92

FIGURA 16 - Desdobramento das diretrizes pelo método B .....................................92

FIGURA 17 - Cadeia de relações entre os indicadores das diferentes perspectivas.....94

FIGURA 18 - Matriz de priorização dos objetivos....................................................97

FIGURA 19 - Esquema de uma distribuição simétrica (nominal-é-melhor) com limite

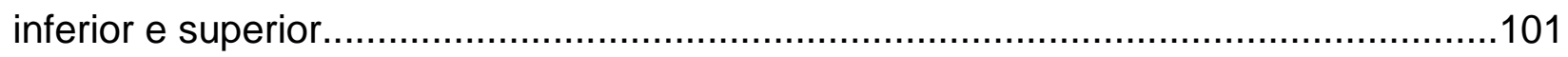

FIGURA 20 - Esquema de uma distribuição simétrica (nominal-é-melhor) com limite inferior e superior...

FIGURA 21 - Esquema de uma distribuição assimétrica à direita (menor-é-melhor) com

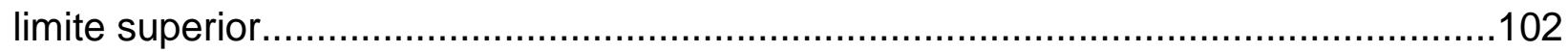

FIGURA 22 - Farol de Nível de Serviço - FNS ...................................................104

FIGURA 23 - Fluxo das etapas de implantação do sistema de indicadores.................105

FIGURA 24 - Farol de Nível de Serviço com indicadores consolidados.......................118 


\section{LISTA DE TABELAS}

TABELA 1 - Matriz Quantum de medição de desempenho ..........................................42

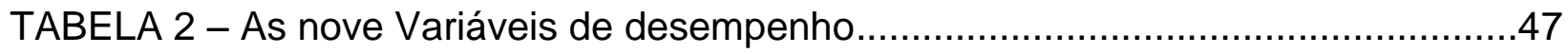

TABELA 3 - As nove variáveis de desempenho com perguntas..................................48

TABELA 4 - Medição dos temas financeiros estratégicos............................................64

TABELA 5 - Resumo das principais características dos modelos de avaliação de

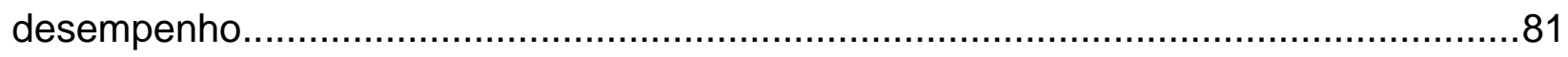

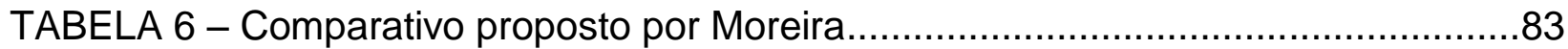

TABELA 7 - Comparativo entre os modelos segundo Rech..........................................84

TABELA 8 - Pontuação utilizada para o preenchimento do corpo da matriz..................96

TABELA 9 - Relação das iniciativas estratégicas levantadas...................................112

TABELA 10 - Relação dos indicadores operacionais............................................117

TABELA 11 - Descrição detalhada dos indicadores de desempenho ..........................119 


\section{LISTA DE SIGLAS E ABREVIATURAS}

BSC Balanced Scorecard GPD .Gerenciamento por Diretrizes

PDCA. Plan, Do, Check, Act (Planejar, Fazer, Checar, Atuar)

TQM Total Quality Management (Gestão da Qualidade Total) $\mathrm{RH}$ Recursos Humanos FNS. .Farol de Nível de Serviço 


\section{SUMÁRIO}

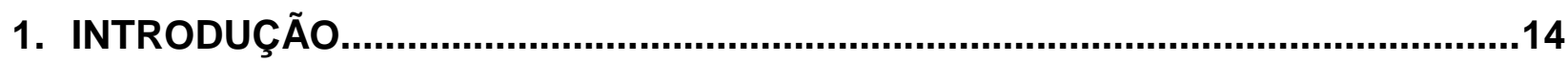

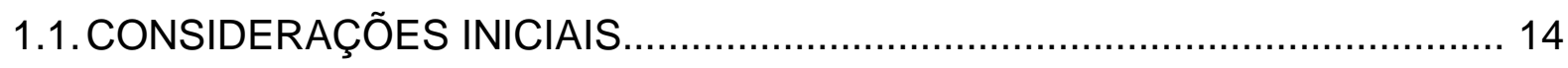

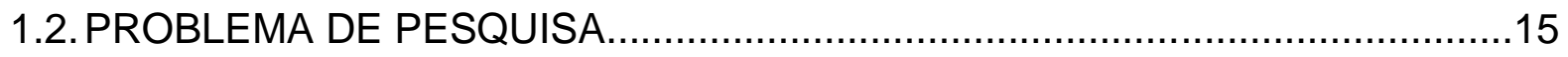

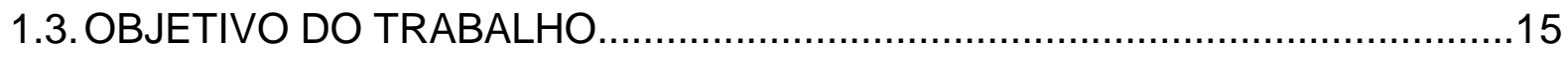

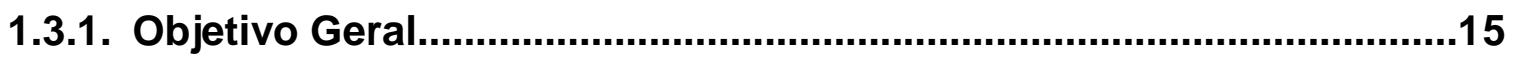

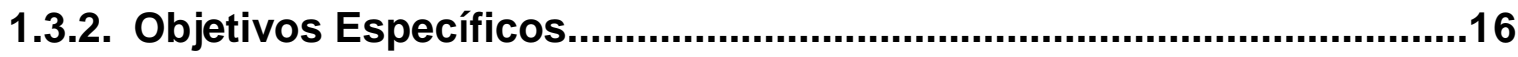

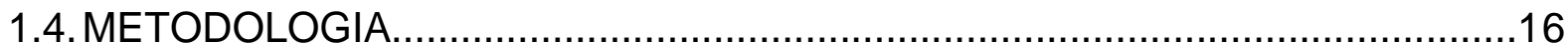

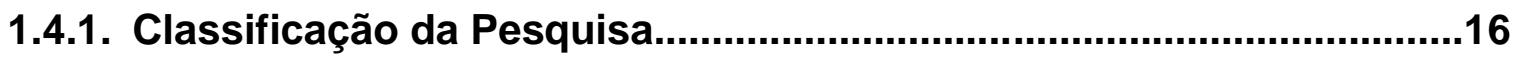

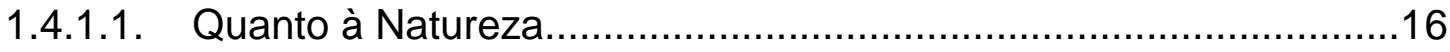

1.4.1.2. Quanto à Forma de Abordagem do Problema..............................17

1.4.1.3. Quanto aos Objetivos da Pesquisa............................................17

1.4.1.4. Quanto aos Procedimentos Técnicos..........................................17

1.4.2. Pressupostos Básicos...........................................................................18

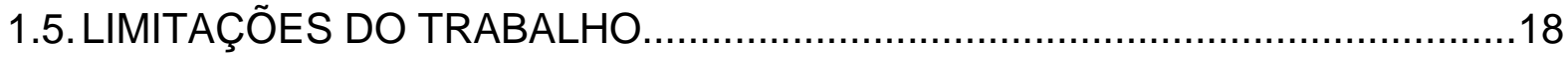

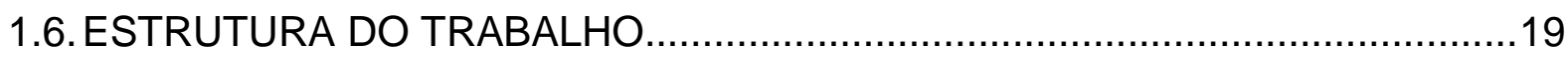

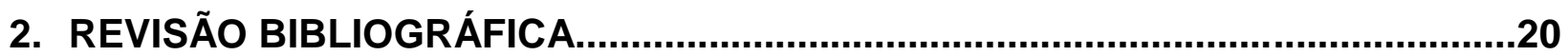

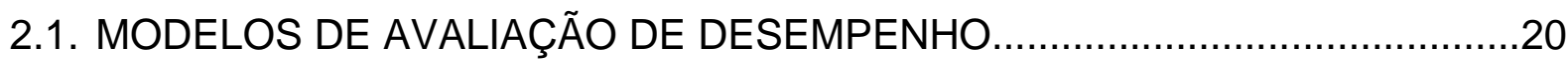

2.1.1. Gerenciamento pelas Diretrizes (Hoshin Kanri).........................23

2.1.1.1. Benefícios do Hoshin Kanri........................................25

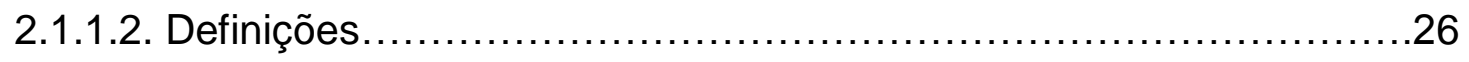

2.1.1.3. Desdobramento das Diretrizes..................................28

2.1.1.4. Implementação Básica do Hoshin Kanri...............................30

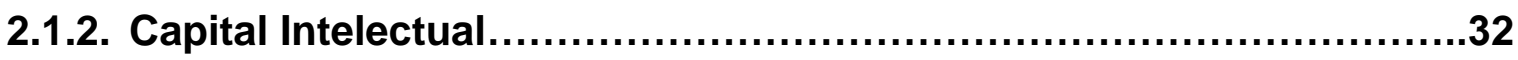

2.1.2.1. Focos do Capital Intelectual............................................ 35

2.1.2.2. Gestão do Capital Intelectual........................................ 38

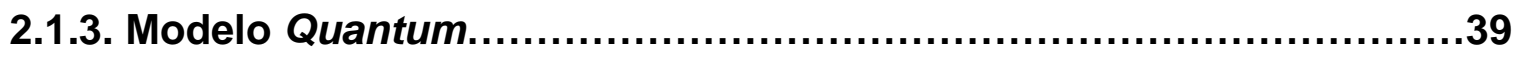

2.1.3.1. Geradores do Modelo Quantum de Medição de Desempenho.........42

2.1.3.2. Facilitadores da Implementação do Modelo..............................43 
2.1.3.3. Processo do Modelo de Desempenho Quantum e Melhoria

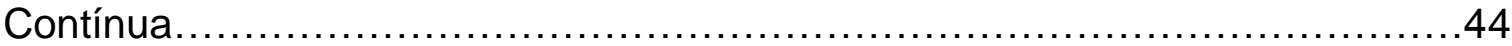

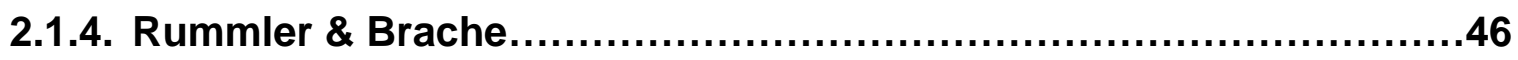

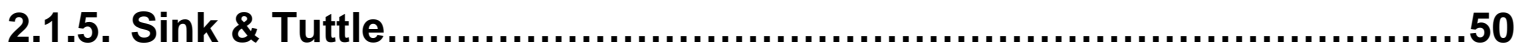

2.1.6. Balanced Scorecard (BSC) ................................................55

2.1.6.1. Objetivos do Balanced Scorecard ..................................58

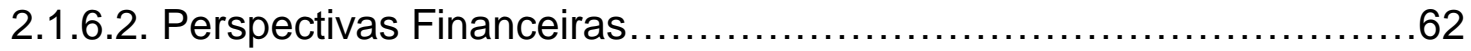

2.1.6.3. Perspectivas dos Clientes........................................64

2.1.6.4. Perspectivas dos Processos Internos..............................66

2.1.6.5. Perspectiva de Aprendizagem e Crescimento........................69

2.1.6.6. Relações de Causa e Efeito..........................................72

2.1.6.7. Mapas Estratégicos.............................................74

2.1.6.8. Número de Medidas para cada Scorecard e Perspectiva..............79

2.1.6.9. Pontos Importantes para o Sucesso do Balanced Scorecard...........79

2.2. COMPARATIVO ENTRE OS MODELOS DE AVALIAÇÃO DE DESEMPENHO

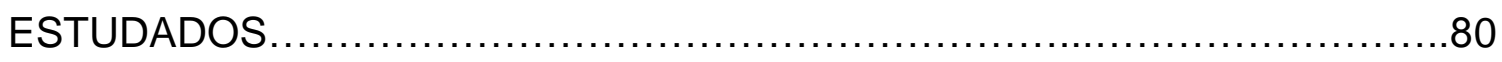

2.3. CONSIDERAÇÕES QUANTO AOS MODELOS DE AVALIAÇÃO DE DESEMPENHO ESTUDADOS.

3. PROPOSTA DE MODELO PARA IMPLANTAÇÃO DE UM SISTEMA DE

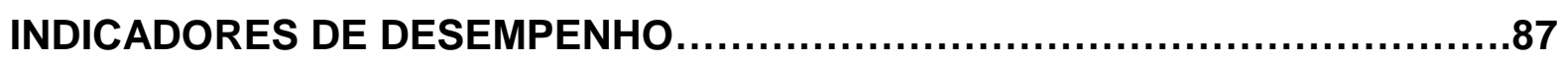

3.1. CRIAÇÃO DAS DECLARAÇÕES DA MISSÃO E DA VISÃO ....................88 3.2. DEFINIÇÃO DAS PERSPECTIVAS E IDENTIFICAÇÃO DOS OBJETIVOS ESTRATÉGICOS PARA AS MESMAS

3.3. DESDOBRAMENTO DOS OBJETIVOS ESTRATÉGICOS DA ALTA ADMINISTRAÇÃO 91

3.4. ESTUDO DAS RELAÇÕES DE CAUSA E EFEITO $\ldots \ldots \ldots \ldots \ldots \ldots \ldots \ldots \ldots \ldots$

3.5. IDENTIFICAÇÃO DOS PONTOS FORTES E PONTOS FRACOS ................94

3.6. LEVANTAMENTO DAS INICIATIVAS ESTRATÉGICAS .........................94

3.7. PRIORIZAÇÃO DAS INICIATIVAS ESTRATÉGICAS .........................95

3.8. ESTABELECIMENTO DOS INDICADORES OPERACIONAIS E

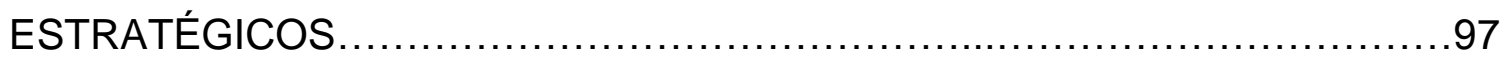

3.9. ESTABELECIMENTO DAS METAS E ESPECIFICAÇÕES PARA CADA INDICADOR. 
3.9.1. Distribuição de indicadores do tipo nominal-é-melhor.......................100

3.9.2. Distribuição de indicadores do tipo maior-é-melhor...........................101

3.9.3. Distribuição de indicadores do tipo menor-é-melhor.........................102

3.9.4. Definição pelos responsáveis pela coleta de dados e ações

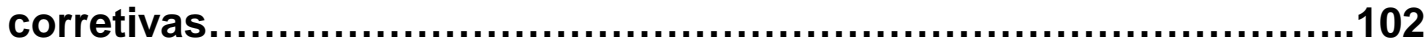

3.9.5. Identificação dos resultados essenciais (indicadores de ocorrência) e dos vetores de desempenho (indicadores de tendência).....................103

3.10. GERAÇÃO DE RESULTADO DO MODELO PROPOSTO.....................103

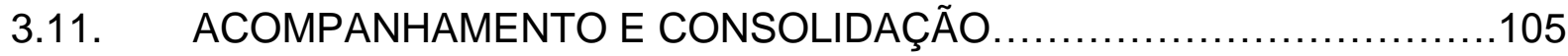

4. APLICAÇÃO DO SISTEMA DE INDICADORES DE DESEMPENHO.....................106 4.1. CRIAÇÃO DAS DECLARAÇÕES DA MISSÃO E DA VISÃO ...................106 4.2. DEFINIÇÃO DAS PERSPECTIVAS E IDENTIFICAÇÃO DOS OBJETIVOS ESTRATÉGICOS PARA AS MESMAS .......................................107

4.3. DESDOBRAMENTO DOS OBJETIVOS ESTRATÉGICOS DA ALTA

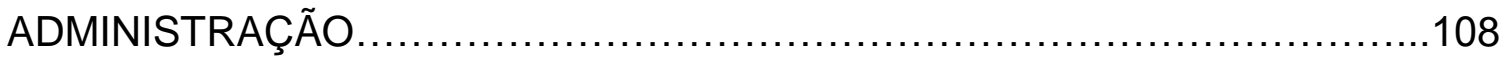

4.4. ESTUdO DAS RELAÇÕES DE CAUSA E EFEITO ENTRE AS PERSPECTIVAS PARA OS OBJETIVOS ESTRATÉGICOS..........................109

4.5. IDENTIFICAÇÃO DOS PONTOS FORTES E PONTOS FRACOS ...............110

4.6. LEVANTAMENTO DAS INICIATIVAS ESTRATÉGICAS .......................111

4.7. PRIORIZAÇÃO DAS INICIATIVAS ESTRATÉGICAS MELHOR ALINHADAS COM OS OBJETIVOS ESTRATÉGICOS ........................................113

4.8. ESTABELECIMENTO DOS INDICADORES OPERACIONAIS......................114

4.9.GERAÇÃO DE RESULTADO DO MODELO PROPOSTO.............................117

4.10. RESULTADOS ALCANÇADOS NO FNS VERSUS RECOMPENSA.............120

5. CONCLUSÕES E SUGESTÕES PARA TRABALHOS FUTUROS.........................122

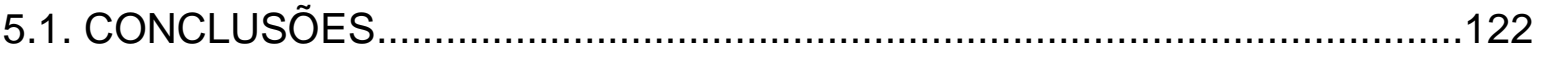

5.2. SUGESTÒES PARA TRABALHOS FUTUROS.........................................124

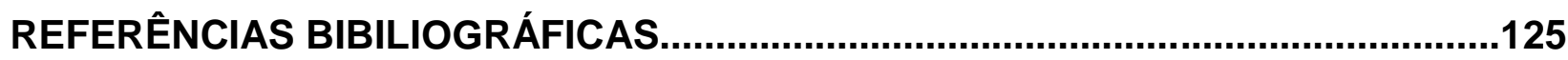




\section{CAPÍTULO 1: INTRODUÇÃO}

\subsection{Considerações Iniciais}

O ambiente de negócios, seja ele de produtos ou serviços, encontra-se hoje dentro de um contexto altamente competitivo e num processo acelerado de mudanças. Frente a um cenário com características tão dinâmicas e de elevada competitividade, as organizações estão buscando novas estratégias e sistemas gerenciais que lhes garantam vantagem competitiva.

Em termos de estratégia, algumas empresas buscam eficiência e eficácia desenvolvendo uma visão clara de si mesmas, o que significa ter uma gestão do conhecimento bem elaborada e bem aplicada. Em termos de sistema gerencial, muitas ferramentas foram desenvolvidas nas últimas décadas a fim de atender a uma nova dinâmica do mercado. Algumas destas ferramentas apresentam sucesso em situações específicas, mas poucas conseguem dar uma visão completa do desempenho da empresa.

Cada sistema gerencial disponível no mercado possui um enfoque próprio, valorizando um conjunto de dimensões empresariais distintas. Alguns deles com ênfase no valor humano, outros no valor financeiro, nos processos produtivos, entre outros (MARCHESAN; MIORANDO; CATEN, 2003).

De todos os sistemas gerenciais, um dos mais utilizados nas empresas e referenciados na literatura é o Balanced Scorecard (BSC). Por se tratar de um sistema que possui um enfoque com forte alinhamento estratégico e ser bastante abrangente, é tido como um dos sistemas que melhor traduz a realidade da empresa (MARCHESAN; MIORANDO; CATEN, 2003). 


\subsection{Problema de Pesquisa}

O sucesso de uma Organização está relacionado com a sua capacidade de identificar oportunidades, criar estratégias e levá-las a cabo dentro dos prazos e metas estabelecidas. No entanto, ainda há certa carência de desenvolvimento de modelos que traduzam a eficiência e a eficácia das empresas, bem como a identificação dos fatores para alavancar a competitividade.

Para minimizar esta limitação, faz-se necessário suprir as Organizações com um mapeamento adequado dos processos e suas interfaces internas e externas de forma a permitir um melhor entendimento, e das necessidades de melhoria.

Conforme lembra Minayo et al. (2001, p.17), pesquisa vincula pensamento e ação, por isso "nada pode ser intelectualmente um problema, se não tiver sido, em primeiro lugar, um problema da vida prática".

Desta forma, formulou-se o problema desta dissertação:

- Propor modelo para implantação de um sistema de indicadores de desempenho, de modo a auxiliar empresas, entidades de classe e formadores de políticas empresariais, a identificar os objetivos comuns, alinhar seus planejamentos estratégicos e buscar melhorias.

\subsection{Objetivo do Trabalho}

O objetivo deste trabalho está dividido em principal e secundário.

\subsubsection{Objetivo Principal}

O objetivo principal desta dissertação é propor um modelo para implantação de um sistema de indicadores de desempenho. 


\subsubsection{Objetivo Secundário}

Para o alcance do objetivo principal deste trabalho, é necessário atender alguns objetivos secundários, a saber:

- Realizar revisão bibliográfica sobre medição de desempenho, e revisar trabalhos já desenvolvidos, identificando as possibilidades de alinhamento com o presente trabalho.

- Dentre os modelos de avaliação de desempenho levantados, adaptar um modelo para implantação.

- Realizar aplicação rápida do modelo proposto no departamento de logística em uma empresa de mineração.

\subsection{Metodologia}

A descrição da metodologia empregada neste estudo foi subdividida em: classificação da pesquisa e pressupostos básicos.

\subsubsection{Classificação da Pesquisa}

Uma pesquisa pode ser classificada de quatro formas: quanto à natureza, quanto à forma de abordagem do problema, quanto aos objetivos e quanto aos procedimentos técnicos (SILVA e MENEZES, 2000). A seguir, é feita a classificação desta pesquisa, conforme esta abordagem discutida pelas autoras.

\subsubsection{Quanto à natureza}

Quanto à natureza, uma pesquisa pode ser classificada em: básica ou aplicada (SILVA e MENEZES, 2000, p.20). Esta dissertação é uma pesquisa aplicada porque 
objetiva discutir teoricamente a medição de desempenho empresarial, propor um modelo específico para o processo de desenvolvimento e implantação de indicadores de desempenho e realizar sua aplicação de forma rápida.

\subsubsection{Quanto à Forma de Abordagem do Problema}

Quanto à forma de abordagem do problema, uma pesquisa pode ser classificada em qualitativa ou quantitativa (SILVA e MENEZES, 2000, p.20). Esta pesquisa possui características qualitativas.

Qualitativas porque possui características citadas por Silva e Menezes (2000, p.20) como a interpretação de fenômenos e a atribuição de significados, a utilização do ambiente natural como fonte dos dados e a ação do pesquisador como instrumento chave para a análise de dados.

\subsubsection{Quanto aos Objetivos da Pesquisa}

Quanto aos objetivos, uma pesquisa pode ser classificada em exploratória, descritiva ou explicativa (SILVA e MENEZES, 2000, p. 21; GIL, 1993, p.45). Esta pesquisa tem características de uma pesquisa predominantemente exploratória, porque envolve como procedimento, principalmente a pesquisa bibliográfica.

Ainda segundo Gil (1993), a presente pesquisa também pode ser classificada como exploratória, uma vez que busca proporcionar maior familiaridade com o problema estudado, com vistas a torná-lo explícito ou a construir hipóteses.

\subsubsection{Quanto aos Procedimentos Técnicos}

Quanto aos procedimentos técnicos, uma pesquisa pode ser bibliográfica, documental, experimental, levantamento, estudo de caso, pesquisa-ação ou pesquisa participante (SILVA; MENEZES, 2000, p. 21-22; GIL, 1993, p. 48). 
Esta pesquisa foi realizada respeitando os seguintes procedimentos técnicos:

- Pesquisa bibliográfica: a partir da identificação do tema do trabalho, realiza-se uma pesquisa bibliográfica, com a consulta de livros, jornais, dissertações e teses defendidas, periódicos nacionais e internacionais.

\subsubsection{Pressupostos Básicos}

Os pressupostos básicos deste trabalho são:

- As Organizações que conseguem ter foco, alavancam o seu desempenho, de acordo com Kaplan e Norton (2001, p. 24). Em uma empresa, se houver foco nos objetivos a serem alcançados por ela e pelos parceiros, então os ganhos poderão ser maximizados, tornando-a mais competitiva.

- Quando as Organizações buscam melhorias internamente, percebem que algumas ações dependem do envolvimento dos parceiros ou clientes, sejam eles internos ou externos. Se houver medição de desempenho dos serviços prestados, as empresas envolvidas poderão obter melhorias que elas não conseguiriam se cada uma agisse isoladamente.

\subsection{Limitações do Trabalho}

O presente trabalho não pretende esgotar o tema proposto, modelos de avaliação de indicadores de desempenho, estando sujeito a algumas limitações.

Esta dissertação não se propõe ao desenvolvimento de estratégias. 
A estrutura de gestão das Organizações pode facilitar ou dificultar a implantação de um sistema de medição de desempenho como se propõe neste trabalho. Porém, neste trabalho não será abordado esse tema, apesar de sua grande importância.

\subsection{Estrutura do Trabalho}

Este trabalho está estruturado em cinco capítulos, conforme descrito a seguir.

- Capítulo 1 discute informações que se configuram como relevantes para a compreensão inicial do trabalho e sua contextualização. São focos dessa primeira parte as considerações iniciais, o tema e objetivos, as justificativas do tema e dos objetivos, a metodologia proposta, as limitações do trabalho e a estrutura da dissertação.

O capítulo 2 apresenta uma revisão bibliográfica objetivando dar embasamento e uniformidade aos conceitos utilizados na dissertação, enfocando elementos ligados ao planejamento estratégico, aos indicadores de desempenho.

O capítulo 3 é apresentado o modelo proposto para a implantação de um sistema de indicadores de desempenho.

O capítulo 4 apresenta-se a aplicação rápida do modelo no departamento de logística em uma empresa de mineração.

O capítulo 5 apresenta-se a conclusão do estudo desenvolvido e a sugestão para trabalhos futuros. 


\section{CAPÍTULO 2: REVISÃO BIBLIOGRÁFICA}

\subsection{Modelos de Avaliação de Desempenho}

Segundo Sink \& Tuttle (1993), uma medição tem por objetivo verificar e melhorar o desempenho, trazendo a percepção do quanto um sistema está ou não sob controle. Como complemento, Rummler \& Brache (1994) propõe que uma organização é um sistema que deve ser gerenciado a fim de se obter saídas que sejam consistentes e de alto nível. Este sistema deve ser medido para que se possa monitorar, controlar e aperfeiçoar seu desempenho. Sem medidas os gerentes não têm base para:

- Comunicar especificamente as expectativas de desempenho dos colaboradores;

- Dar ciência do que está ocorrendo na organização;

- Identificar falhas de desempenho que possam ser analisadas e eliminadas;

- Fornecer "feedback" que compare o desempenho a um padrão estabelecido;

- Identificar o desempenho que merece recompensa;

- Apoiar a tomada de decisões sobre recursos, planos, políticas, esquemas e estruturas.

Com relação aos colaboradores de outros níveis também não teriam base para:

- Saber especificamente o que a organização espera deles;

- Avaliar seu próprio desempenho e seu próprio "feedback";

- Identificar pontos para aperfeiçoar seu desempenho;

- Gerar suas próprias recompensas.

Da mesma forma Hansen (1996) salienta que para a organização manter a competitividade a mesma deve estar alinhada com a estratégia escolhida e o seu sistema de medição deve induzir nos seus processos os objetivos e as estratégias, sendo que este último deve ser o elo de ligação entre os objetivos e a operação da organização. 
Muller (2003) coloca que após a definição do negócio, missão, valores e ser traçada a estratégia da organização devem ser respondidas as seguintes perguntas: (I) a empresa está alcançando suas metas? (ii) ela está no caminho definido pela visão? (iii) a missão da organização está sendo cumprida? (iv) os empregados estão cientes de e alinhados com estratégia da empresa? Conseqüentemente, não basta à organização definir a rota, a mesma precisa medir se está nela. São neste ponto que se inserem as medidas de desempenho.

Assim sendo, a rigor qualquer sistema de medição deve começar na visão de futuro que a organização tenha definido para si e à visão segue-se a estratégia através dos objetivos estratégicos. Os objetivos estratégicos devem ser transformados em ações tangíveis. No sentido de verificar seu desenvolvimento é estruturado o sistema de medidas de desempenho (MOREIRA, 1996).

O sistema de medição é um componente integral do processo de aprimoramento de performance. Na verdade, esse aprimoramento é a finalidade principal, sendo que o sistema de medição e o ciclo de aprimoramento são os meios (SINK \& SMITH, 1999).

A organização precisa saber se está saindo-se melhor hoje do que ontem, ou se está melhor ou pior do que seus concorrentes. Para tanto, necessita-se de um modelo que avalie a gestão a identificar, medir e gerenciar o maior número possível de indicadores de desempenho, verificando se a empresa está no caminho certo através do aprimoramento da performance em alguns atributos chaves, propiciando à empresa vantagem competitiva. Alcança-se esta meta através de um sistema de performance (MOREIRA, 1996).

Com o objetivo final é o aprimoramento da performance e, segundo Harrington (1993), se não se pode medir não se pode controlar, se não se controla não se pode gerenciar, se não se gerencia não se pode melhorar, a medição adquire um papel de importância vital na gestão das organizações. 
Conforme Sink \& Tuttle (1990) um passo importante no processo de gestão de performance é o foco no aprimoramento do processo de medição e avaliação do desempenho. Deve-se desenhar e redesenhar o sistema de medição com relação aos critérios de efetividade, qualidade, produtividade, qualidade no tempo de vida e finalmente inovação.

O foco do aprimoramento da gestão de performance não deve ser a satisfação dos clientes ou moral dos empregados; na verdade, o motivo real pelo qual as empresas necessitam desse processo de aprimoramento é o de aumentar os lucros (HARRINGTON, 1997). O processo de aprimoramento de performance não é parte do jogo, hoje ele é o jogo, pois todos em uma organização querem transformar as operações para melhor.

Conforme uma pesquisa realizada em 2003, em 708 empresas nos 5 continentes, foi identificado um grande incremento no uso de ferramentas de gestão de desempenho no ano de 2002, um ano de grandes turbulências econômicas. Esta explicação deriva de que, em tempos difíceis, as empresas precisam que seja obtida a maior eficiência possível de todos os instrumentos de gestão (RIGBY, 2003).

Se uma organização tem medidas de desempenho em excesso, e tudo é medido, as pessoas ficam sobrecarregadas e acabam não produzindo. Muitas organizações gastam mais tempo coletando dados para medidas do que lidando com o cliente.

Para Hronec (1994) as organizações atendem seus clientes por meio de processos que cruzam os organogramas funcionais e caso a organização focalize apenas o desempenho funcional os resultados globais serão sub-otimizados, pois serão desenvolvidas metas e medidas de desempenho de forma independente, somente melhorando umas em detrimento de outras. Assim sendo, no sentido de entender e aprimorar, a organização deve focalizar seus processos. 
Visando suprir esta necessidade que as organizações como um todo possuem de monitorar e gerenciar seu desempenho, uma série de modelos de gestão são propostos. Nesta dissertação pretendem-se abordar alguns destes conceitos. Os modelos que se pretende abordar neste trabalho são os seguintes:

- Gerenciamento pelas diretrizes (Hoshin Kanri);

- Capital Intelectual;

- Modelo Quantum;

- Rummer \& Brache;

- Sink \& Tuttle;

- Balanced Scorecard (BSC).

\subsubsection{Gerenciamento pelas Diretrizes (Hoshin Kanri)}

A abordagem de gestão Hoshin Kanri foi inicialmente desenvolvida no Japão nos anos 60 e apresentada e desenvolvida para o ocidente em um texto traduzido do Japonês e editado por Yoji Akao em 1991 (WITCHER, 2002). A tradução literal do Japonês de Hoshin Kanri é: Ho significa método; Shin significa metal brilhante mostrando a direção e por fim, Kanri significa planejamento. No sentido de facilitar o entendimento traduz-se como: determinar a direção estratégica (TENNANT \& ROBERTS, 2000).

Hoshin Kanri é um dos três componentes do TQM (Total Quality Management Gerenciamento da Qualidade Total), sendo que os outros dois são o gerenciamento da rotina e os times de melhoria de qualidade. O Hoshin Kanri trata do gerenciamento das diretrizes da alta direção (WOOD \& MUNSHI, 1991).

Conforme Witcher \& Butterworth (2001) o modelo "Hoshin Kanri" é um sistema de gestão corporativo que combina a gestão estratégica e a gestão operacional fazendo a ligação do alcance das metas da alta direção com a gestão diária no nível operacional. Atualmente o modelo é reconhecido e aplicado em grandes multinacionais japonesas, 
incluindo suas subsidiárias gerenciadas em países estrangeiros. Porém, fora do Japão sua relevância não é largamente reportada (WITCHER \& BUTTERWORTH, 2001; TENNANT \& ROBERTS, 2000).

O processo de planejamento é o primeiro passo, através do mesmo a alta direção determina a visão e os objetivos da organização. A média gerência estuda estes objetivos e determina a forma como os mesmos serão alcançados. Após a determinação dos planos de ação ter sido acordado, são definidos equipes de implementação com responsabilidades de executar os planos de ação. O processo Hoshin Kanri começa a partir da especificação pela alta direção das metas para a média gerência. Após, estes projetos às equipes de implementação. Este processo é feito a partir de uma negociação entre os três grupos e é chamado "catchball", espécie de jogo japonês onde pessoas participam de diálogo da mesma maneira que um grupo de jovens brinca de apanhar a bola. Os três grupos têm que negociar até concordarem com as metas e planos de ação (BEECROFT, 1999; AKAO, 1997).

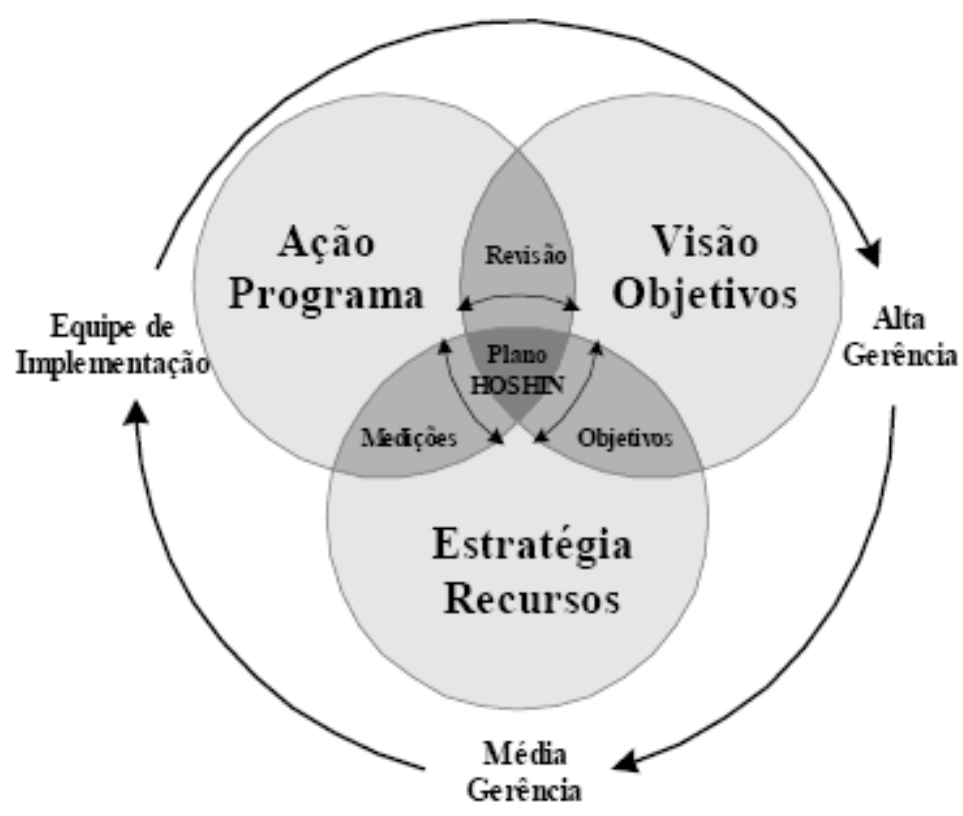

Figura 1 - Modelo Hoshin Kanri

Fonte: adaptado de Akao (1997) 
Muitas vezes a lacuna entre performance de uma empresa e a necessária para seu sucesso é de tal monta que somente a melhoria contínua não é suficiente para que a mesma alcance a performance necessária. Nestes casos a empresa precisa de um modelo de otimização chamado Breakthrough (ruptura). Neste modelo frequentemente é necessário um redesenho de todos os processos para corrigir problemas crônicos. Conforme Tennant \& Roberts (2000) o Hoshin Kanri é a metodologia que melhor se adéqua ao Breakthrough, pois sua abordagem traduz uma visão de longo prazo da empresa para prioridades estratégicas que são desdobradas em planos anuais os quais são controlados e ajustados regularmente.
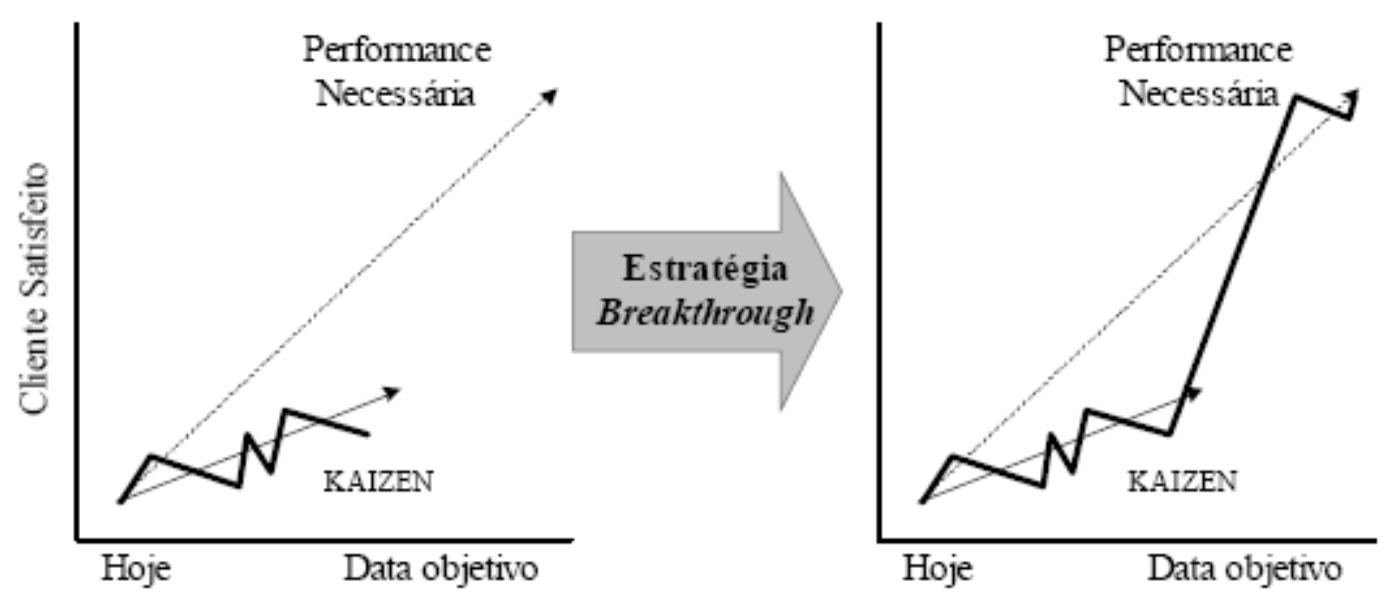

Figura 2 - Performance breakthrough

Fonte: adaptado de Tennant \& Roberts (2000)

\subsubsection{Benefícios do Hoshin Kanri}

Conforme Watson apud Akao (1997) a principal vantagem do modelo é a melhoria da comunicação em função do sistema documentado e aberto do planejamento, implementação e revisão. As vantagens específicas são:

- Cada colaborador sabe como o seu trabalho relaciona-se com a operação estratégica (Hoshin) e tática (gerenciamento diário) da empresa; 
- Obtém-se um aprimoramento nas negociações entre as unidades funcionais da empresa devido ao aprendizado propiciado pelos objetivos essenciais e às estratégias de implementação;

- Devido à revisão do progresso ser estruturada abre-se a possibilidade de uma discussão dos objetivos essenciais do gerenciamento no sentido de aperfeiçoar o sistema-empresa;

- Em função de o modelo ser revisto continuamente na busca de aprimorar o sistema de planejamento operacional da empresa, evita-se deixar um sistema não questionado, estático ou com foco apenas nas finanças.

\subsubsection{Definições}

No sentido de dar início ao primeiro passo, que é o passo do Planejamento, Campos (1996) estabelece algumas definições básicas:

- Planejar é definir o que deve ser feito para atingir a meta;

- Meta é um ponto a ser atingido no futuro e é constituída de três partes: Objetivo gerencial, valor e prazo para alcance da mesma;

- Como todas as coisas estão ligadas em uma relação meio-fins a meta de cada um é estabelecida sempre em relação aos seus fins;

- Gerenciar é atingir a meta, não existe gerenciamento sem meta;

- Diretor é aquele que dá a direção e a direção é a meta;

- Problema é um resultado indesejável de um processo, conseqüentemente o problema de cada um é não atingir sua meta;

- Medidas são os meios ou métodos específicos para que se atinja a meta;

- Diretriz é composta de uma meta, estabelecida sobre os fins e das medidas prioritárias e suficientes para que se atinja a meta, esta é estabelecida para resolver problemas e usa-se o processo de planejamento para estabelecê-la. 
Conforme Akao (1997), metas podem ser definidas como "resultados esperados". Meios podem ser definidos como "direções para atingir a meta". Os meios mostram, em outras palavras, como atingir a meta.

Geralmente, a diretriz é utilizada num sentido mais amplo, de maneira que a meta e os meios combinados possam ser denominados com uma diretriz. Se os meios mostram a direção, então se esclarecem os passos específicos para atingir as metas baseando-se nestes meios. Assim se pode determinar um plano de ação com o cronograma.

Segundo Campos (1996) planejar consiste em estabelecer um plano, ou seja, um conjunto de medidas prioritárias e suficientes para atingir uma meta. $O$ processo de planejar consiste em quatro etapas distintas: (i) conhecer a meta e conseqüentemente o problema; (ii) analisar o fenômeno (fins); (iii) analisar o processo (meios); (iv) estabelecer o plano (meios). O Hoshin Kanry pode ser entendido em síntese, pela figura.

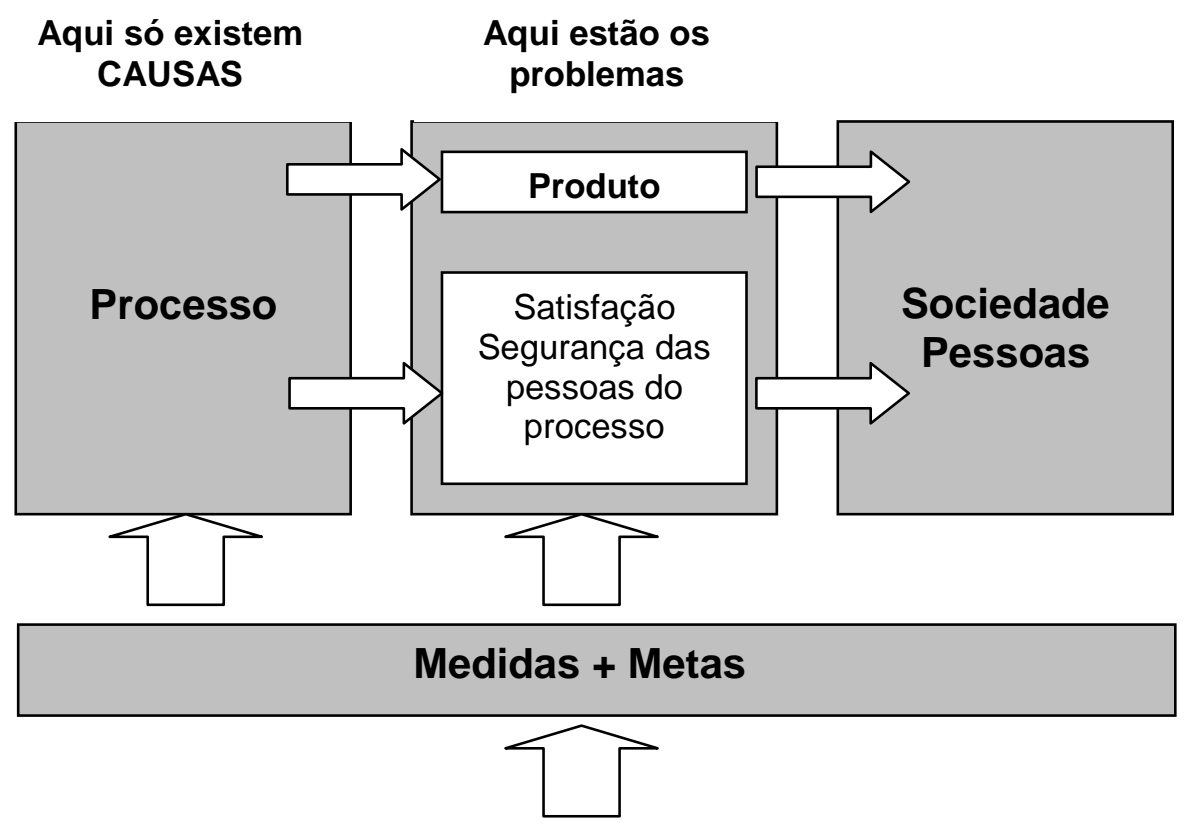

DIRETRIZ

Figura 3 - Conceito de diretriz e problema

Fonte: adaptado de Campos (1996) 


\subsubsection{Desdobramento de Diretrizes}

O desdobramento de diretrizes consiste em dividir uma diretriz em várias outras diretrizes sob responsabilidade de outras pessoas, sendo que as mesmas ficam intimamente ligadas em um relacionamento meio-fim. Somente deve-se desdobrar aquilo que é prioritário para $\mathrm{o}$ ano e as diretrizes desdobradas devem garantir 0 cumprimento da diretriz original (CAMPOS, 1996).

As medidas de uma diretriz dividem-se entre: medidas desdobráveis e medidas não desdobráveis, sendo que as primeiras serão executadas pelos níveis hierárquicos inferior ou por outros processos e as segundas serão desdobradas pelo próprio responsável pela diretriz e devem ser transformadas em ação da ferramenta $S W 1 H$, gerando um plano de ação (CAMPOS, 1996).

Segundo Akao (1997) quando se realizar o desdobramento das metas e dos meios de forma independentemente, ambos se tornaram deficientes, pois o primeiro enfatiza somente o resultado possivelmente não levando em conta a causa verdadeira e o segundo tem uma tendência de tornar-se somente um controle formal focado nos métodos. Unir as metas e os meios é a única forma de desdobrar a ambos, para tanto se utiliza a matriz de relações metas-meios. 


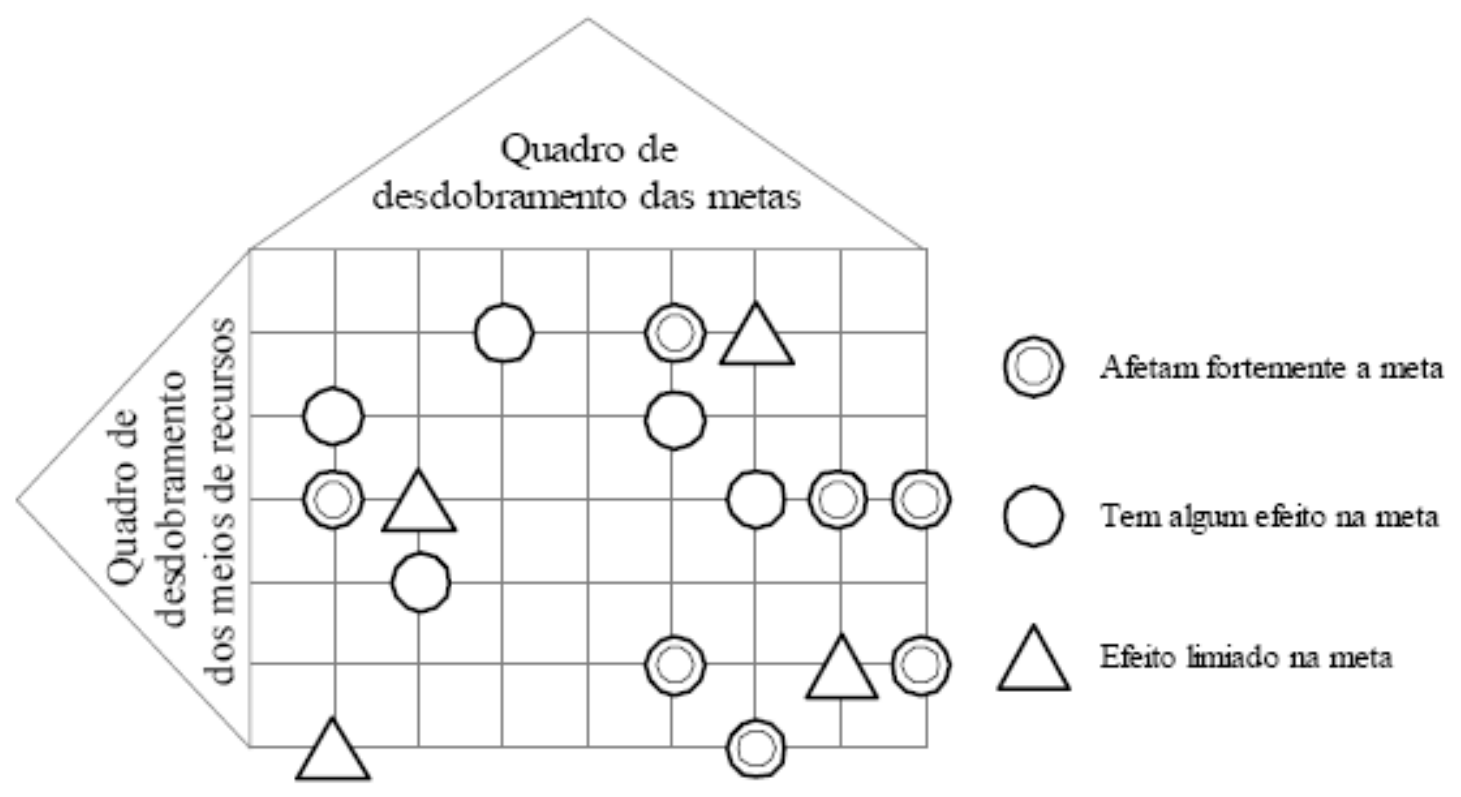

Figura 4 - Matriz de relações metas-meios (quadro conceitual)

Fonte: adaptado de Akao (1997)

Campos (1996) propõem dois métodos para desdobrar uma diretriz: (I) para cada meta, são estabelecidas medidas prioritárias e suficientes para atingi-las e, a partir destas, são originadas novas metas; (ii) as metas devem ser desdobradas em todos os níveis hierárquicos, para depois ser feito o estabelecimento das medidas para cada nível, conforme figura 5 .

MÉTODO 1
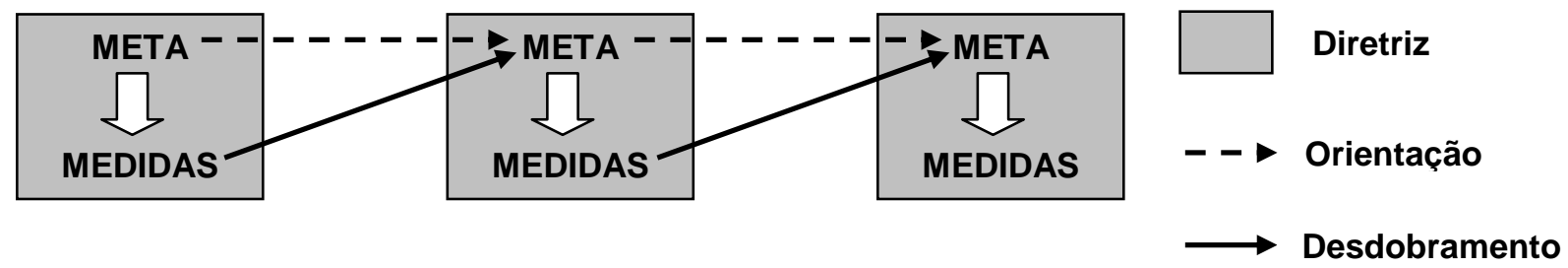

MÉTODO 2

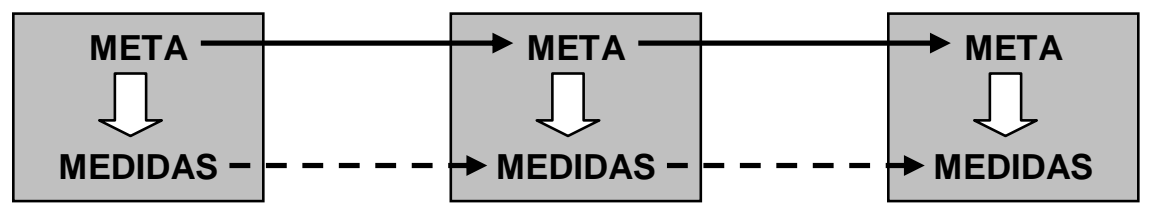

$\sum$ Análise

Figura 5 - Modelo utilizado para desdobrar uma diretriz

Fonte: adaptado de Campos (1996) 


\subsubsection{Implementação Básica do Hoshin Kanri}

O processo de implementação do Hoshin Kanri consiste de dez passos conforme seguem:

- Passo 1 - estabelecer um lema para empresa, uma política de qualidade e um plano de promoção: O modelo inicia-se a partir do estabelecimento, pela gerência do lema da empresa, de um propósito, uma missão ou uma visão gerencial que são apoiados pela política de qualidade e de promoção do controle da qualidade (AKAO, 1997).

- Passo 2 - delinear estratégias gerenciais de longo e médio prazos: Nesta etapa devem-se desenvolver estratégias de rápida adequação a mudanças estabelecendo-se também planos de longo e médio prazo. Os planos devem estar alinhados com os objetivos e prioridades da empresa. A partir da coleta e análise dos dados são estabelecidas prioridades estratégicas para atingir os objetivos de longo e médio prazos (AKAO, 1997).

- Passo 3 - coletar e analisar informações: Nesta etapa são seguidos os seguintes passos (i) analisar os dados de desempenho do ano anterior de modo a compreender os problemas atuais; (ii) estudar as informações (dados previstos) existentes das condições internas para compreensão dos problemas; (iii) estudar as informações (dados previstos) externas de modo a compreender os problemas; (iv) organizar e estratificar os problemas levantados nos processos anteriores, isolando os que são realmente importantes como problemas críticos (AKAO, 1997). No planejamento pelas diretrizes o ciclo PDCA (Plan-do-check-act que significa planejar, fazer, checar e atuar) primeiramente desenvolvido por Walter Shewhart em 1939 troca de ordem para checar (review), atuar (revision), planejar (deployment) e por fim executar (implementation) (WOOD \& MUNSHI 1991). 
- Passo 4 - planejar as metas e os meios: Esta etapa é dividida em três fases (I) a partir da análise dos resultados do ano anterior, determinar as diretrizes e um plano (meios e metas); (ii) preparar uma folha de diretrizes e uma de plano de ação definindo o responsável e o cronograma de execução; (iii) praticar o catchball, conforme descrito acima com os liderados (AKAO, 1997).

- Passo 5 - estabelecer os itens de controle e preparar uma lista dos mesmos: Esta etapa consiste de três passos: (I) Definir os itens de controle para o desdobramento das diretrizes; (ii) elaborar uma lista de itens de controle que especifique os trabalhos, as pessoas encarregadas, a freqüência de controle, o método de controle, os dados de controle, os critérios de tratamento emergencial e outras categorias importantes e, por fim; (iii) uma reunião entre o coordenador, seu liderado e demais pessoas ligadas ao processo (Catchball) (AKAO, 1997).

- Passo 6 - desdobrar a diretriz: A partir do plano de diretrizes obtidas anteriormente procede-se para o desdobramento das mesmas ao longo da estrutura (AKAO, 1997).

- Passo 7 - desdobrar itens de controle.

- Passo 8 - implementar o plano de diretrizes: a implementação é feita baseada no plano de diretrizes, ou do plano de ação, variando de empresa para empresa (AKAO, 1997).

- Passo 9 - verificar os resultados da implementação: Realiza-se o seguinte processo: (I) comparar a meta com os resultados reais e verificar a diferença; (ii) se existem diferenças, analisar o processo buscando as causas; (iii) atuar sobre as causas que fazem maior efeito; (iv) se a medida corretiva surtir efeito, aplicála no plano do próximo ano, caso contrário mencione no plano do próximo ano para não ser repetida; $(v)$ preparar o relatório de situação das diretrizes relatando os resultados alcançados (AKAO, 1997). 
- Passo 10 - preparar o relatório de situação para implementação do hoshin kanri: O relatório de situação relata o PDCA do desdobramento das diretrizes do ano em vigência e deve ser feito quando necessário, para cada trabalho, seção ou departamento e distribuído para seus respectivos departamentos (AKAO, 1997).

Campos (1996) propõem um modelo de implementação segmentado por faixas semelhantes às artes marciais.

\subsubsection{Capital Intelectual}

Em 1959 Peter Drucker utilizou pela primeira vez o termo "trabalhador do conhecimento". O autor afirma que o conhecimento e não o capital será a nova base de riqueza em uma sociedade pós-capitalista e que as empresas não serão mais medidas por seus tijolos, argamassa e máquinas. Drucker completa que, o conhecimento será o recurso chave e não haverá fronteiras geográficas para o mesmo (BIRKNER \& BIRKNER, 2000).

O capital intelectual representa a maior parte do valor real de uma empresa e é formado por ativos indiretos como: conhecimento organizacional, satisfação do cliente, inovação do produto, disposição dos empregados, patentes e marcas registradas que não são apresentados nos seus demonstrativos financeiros. Pode-se dizer que existe uma lacuna entre o valor da organização, de acordo com seu balanço patrimonial, e o valor indicado pelo mercado e esta lacuna é a origem do capital intelectual (EDVINSSON \& MALONE, 1998).

Em julho de 1994 um grupo formado por representantes de diversos grupos econômicos, acadêmicos e analistas políticos reuniu-se na busca de uma maneira de permitir que o capital intelectual pudesse ser colocado na mesma base firme, comparativa do capital financeiro. Em outubro de 1994 a revista Fortune publicou um artigo com o seguinte titulo: "O ativo mais valioso de sua empresa: O capital intelectual". Porém o real avanço sobre o estudo do Capital Intelectual ocorreu em maio de 1995 
quando uma empresa sueca de seguros e serviços financeiros da Escandinávia chamada Skandia emitiu o primeiro relatório anual público sobre capital intelectual, como relatório suplementar (MELYMUKA, 2000; EDVINSSON \& MALONE, 1998).

E o resultado da aplicação do modelo acima fica claro, quando, após obter um recorde de crescimento de novos negócios e crescimento de vendas no primeiro trimestre de 2004 , da ordem de $75 \%$ superior ao igual período de 2003 , o diretor de operações da Skandia ressalta:

"Este é um começo soberbo para 2004 e demonstra a habilidade e a experiência do nosso time de gestão, em atacar as áreas corretas de foco para desenvolvimento de negócios e contenção de custos enquanto se adaptava para as mudanças demandadas por nosso mercado (RECORD, 2004)".

Edvinsson \& Malone (1998) propõe uma metáfora para facilitar a compreensão do capital intelectual. Uma empresa pode ser considerada um organismo vivo, como uma árvore, assim o que é descrito em organogramas, relatórios anuais, demonstrativos financeiros e outros documentos constituem-se o tronco, galhos e folhas. O investidor busca frutos maduros para colher. O que está imediatamente visível não se constitui a árvore inteira, pois a maior parte do conteúdo está abaixo da superfície no sistema de raízes. Embora o sabor das frutas e a situação das folhas forneçam evidências do estado de saúde da árvore naquele momento, entender o que ocorre nas suas raízes é uma maneira muito eficaz de conhecer o estado de saúde da mesma nos anos vindouros. O estudo do capital Intelectual é o estudo das raízes também, porém das raízes de valor da empresa, através da mensuração dos fatores dinâmicos ocultos da mesma. Estes fatores podem ser:

- Capital Humano: Conhecimento, habilidade, poder de inovação e a habilidade dos colaboradores de uma organização em realizar as tarefas do dia-a-dia, incluindo valores, cultura e filosofia da empresa. Não constitui propriedade da empresa; 
- Capital Estrutural: Equipamentos de informática, softwares, banco de dados, patentes, marcas registradas e toda a capacidade gerencial que apóia a produtividade dos colaboradores, além do capital dos clientes, baseado no relacionamento com os mesmos. Esse capital pode ser considerado propriedade da empresa e assim é passível de negociação.

De tal análise pode-se concluir que o Capital Intelectual nada mais é que a soma do Capital Humano e do Capital Estrutural. O modelo Skandia, conforme pode ser visto na Figura 6, propõe que o capital estrutural pode ser desdobrado na soma do capital de clientes e o capital organizacional e finalmente este último pode ser também desdobrado em capital de inovação e capital de processos.

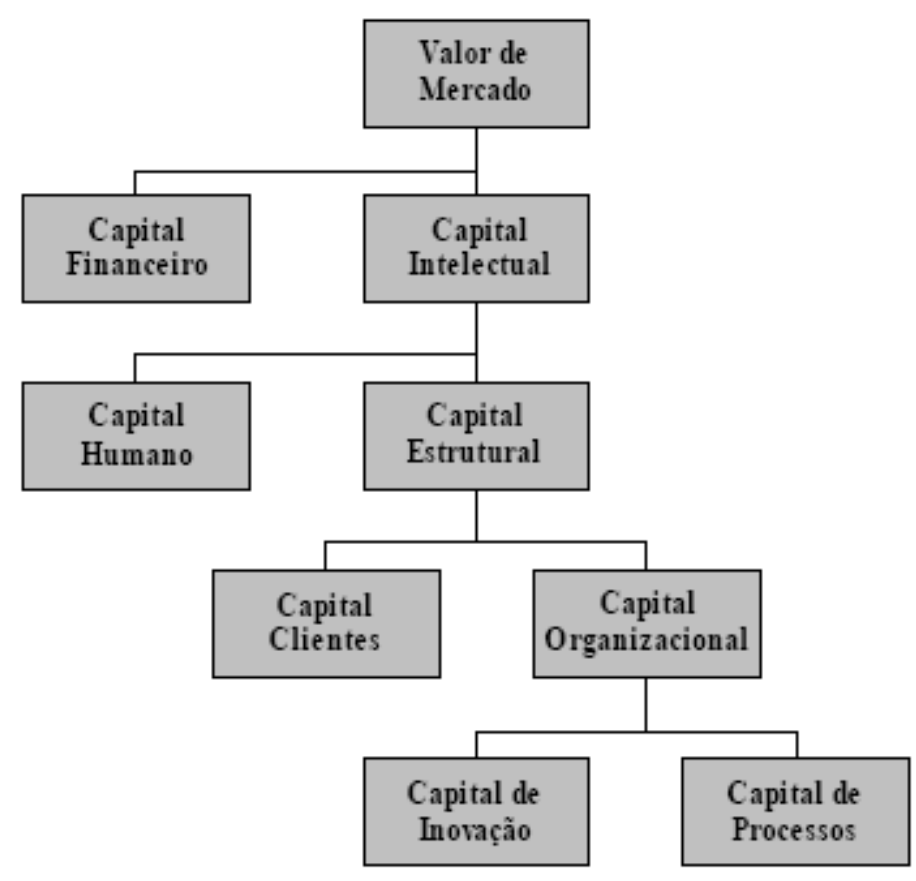

Figura 6 - Esquema Skandia para o valor de mercado através do desdobramento do Capital Intelectual

Fonte: adaptado de Edvinsson \& Malone (1998)

O ponto chave do modelo baseia-se na idéia de que o valor real do desempenho de uma organização está na habilidade da mesma em criar valor sustentável através da 
aplicação de uma visão empresarial e sua estratégia resultante. Através da estratégia, determinam-se os fatores de sucesso que devem ser maximizados. O modelo apresenta estes fatores em quatro áreas distintas de foco: financeira, cliente, processo, renovação e desenvolvimento e, ainda, em uma quinta área partilhada pelas anteriores: humana. E finalmente, determina-se em cada uma das cinco áreas os indicadores para medição de desempenho, e a este modelo holístico a Skandia chamou de Navegador, o qual é apresentado na Figura 9 (EDVINSSON \& MALONE, 1998).

Conforme Olve, Roy \& Wetter (2001), o interesse por acrescentar um foco separado sobre recursos humanos advém do desejo de acentuar a interação entre a sua perspectiva e a dos outros. Assim, por exemplo, a relação existente entre o foco de recursos humanos e o foco de processos é descrita como multiplicadora, pois os resultados são produzidos por pessoal competente, assim como o foco no cliente precisou utilizar o potencial do processo.

Corroborando a visão de Olve, Roy \& Wetter (2001), Sveiby (1998) coloca que as pessoas são os únicos verdadeiros agentes nas empresas, assim sendo, todos os ativos e estruturas são resultados das ações humanas. Enfim, todas dependem das pessoas, para continuar existir.

\subsubsection{Focos do Capital Intelectual}

Os cinco blocos do Navegador Skandia, clientes, processo, humano, financeiro e renovação e desenvolvimento criam uma bússola direcional para a liderança utilizar de modo a focar a capacidade organizacional em direção a áreas de importância estratégica. É estabelecido para cada um destes blocos um conjunto especifico de medidas de performance que melhor monitoram o progresso em direção a atingir o estado de prontidão estratégica (BUKOWITZ, 1997). 
No que tange ao foco financeiro, Edinvisson \& Malone (1998) afirmam que o fluxo do dinheiro gerado por uma empresa se constitui no final a medida de valor mais tangível, como também é a fonte de retribuição em termos de lucros, salários e rendimentos.

No modelo do Capital Intelectual, os demonstrativos financeiros assumem um novo papel, onde todo o Capital Intelectual, caso tenha algum valor, precisa ser convertido em moeda, processo este que pode levar décadas ou horas, mas que efetivamente ocorrerá em algum momento do futuro. Índices de satisfação de clientes, disposição dos empregados e outros análogos devem traduzir-se em receitas maiores, custos fixos menores ou lucros maiores. Conforme ocorre esta conversão, a medida se desloca da renovação e desenvolvimento para clientes e processo para no final realizar-se em lançamento nos demonstrativos financeiros (BUKOWITZ, 1997).

O modelo propõe que novas medidas devem ser refletidas nos balanços patrimoniais enquanto que outras devem ser retiradas através de um processo de tentativa e erro. Este processo deve ocorrer em três fases: (I) dados financeiros preliminares, que são as notas financeiras da empresa de natureza subjetiva, não empírica e não diferenciada; (ii) capitalização Financeira nesta etapa do processo realiza-se a procura, filtragem, tradução e medição das dados financeiros preliminares e, finalmente; (iii) documentação financeira onde estão as tabelas financeiras tradicionais representando a transformação final dos ativos de capital intelectual em recursos financeiros (BUKOWITZ, 1997).

O modelo sugere alguns indicadores de foco financeiro: Ativo total (\$), Ativo total/empregado (\$), Receitas/ativo total (\$), Tempo dedicado aos clientes/número de horas trabalhadas pelos empregados (\%).

No que se refere ao foco no cliente, as organizações aplicam uma quantidade cada vez maior de recursos corporativos, bem como ferramentas tecnológicas de modo a atingir suas metas e manter os clientes satisfeitos, até mesmo em êxtase, pelo maior 
período possível. O sucesso de uma empresa que encontrou a combinação certa de recursos humanos e tecnologia elevando mais o nível de serviços necessários para vencer a concorrência, estabelece um novo patamar de competição. A partir da percepção deste novo patamar de serviços pelos clientes, os mesmos passam a exigir das demais empresas este patamar. O resultado deste processo é que cada vez mais as empresas são forçadas a concorrer para garantir a satisfação plena de seus clientes.

A avaliação do capital intelectual com foco do cliente consiste em encontrar parâmetros que captem a recente realidade das relações eficazes e inteligentes entre empresas e clientes. Os parâmetros em termos de índices e indicadores devem capturar de forma cumulativa o fluxo de relacionamentos entre empresas e clientes em potencial.

Edvinsson \& Malone (1998) sugerem alguns indicadores para este foco: Participação de mercado, número de clientes, número de clientes perdidos, acesso através do telefone, classificação dos clientes, número de visitas dos clientes à empresa, cobertura de mercado, índice de ociosidade.

Já, no que se refere ao foco no processo, o modelo trata do papel tecnológico como forma de apoiar a criação de valor global da empresa. A tecnologia tornou as empresas mais rápidas, adaptáveis e permitiu uma maior flexibilidade organizacional e por fim, através de ferramentas de intercâmbio eletrônico de dados permitiu a adoção de novas formas de relacionamento virtual com fornecedores e clientes. Assim todos estão comprometidos com a espiral tecnológica ascendente que poderá criar cada vez mais riqueza e produtividade.

Alguns indicadores sugeridos para o foco no processo pelo autor são: despesas administrativas/ativos administrados, despesas administrativas/receita total, custo dos erros administrativos/receitas gerenciais, contratos redigidos sem erros, PCs/empregados, Laptops/empregados, despesas administrativas/empregado (\$), despesas de $\mathrm{Tl} /$ empregado (\$), Despesas com Tl/despesas administrativas (\%). 
Por fim, no que tange ao foco na renovação e desenvolvimento, busca-se projetar o futuro imediato, verificando o que a empresa está fazendo no presente de modo a preparar-se de forma adequada para captar oportunidades futuras.

O modelo propõe, a partir da experiência, que existem seis áreas distintas de encarar e se preparar para as mudanças iminentes do ambiente competitivo, promovendo sua própria renovação como resposta. As mesmas são: Clientes, atração no mercado, produtos e serviços, parceiros estratégicos, infra-estrutura e empregados. Relacionando mudanças na base de clientes, investimento em inteligência de mercado, quantos produtos e serviços novos estão em desenvolvimento, quanto à empresa investe no desenvolvimento de parcerias estratégicas, qual o valor, idade e expectativa dos equipamentos de apoio ao capital organizacional, o nível de instrução dos colaboradores da empresa, etc.

Alguns indicadores sugeridos para o foco no processo são: despesas com desenvolvimento das competências/empregado (\$), índice de "empowerment dos empregados, despesas de marketing/Cliente (\$), porcentagem das horas de treinamento (\%), despesas de $\mathrm{R} \& \mathrm{D} /$ despesas administrativas (\%), despesas de treinamento/empregado (\$), número de empregados empreendedores/número total de empregados.

\subsubsection{Gestão do Capital Intelectual}

O modelo Skandia antes de ser um instrumento para investidores e analistas constitui-se em uma importante ferramenta para a liderança da empresa, pois a gestão do capital intelectual é mais do que a simples gestão do conhecimento ou da propriedade intelectual é, na realidade a alavancagem da combinação entre capital humano e capital estrutural.

O processo de gestão eficaz do capital intelectual é formado por quatro etapas: 
- Compreensão dos componentes que demonstre ter capacidade de criação e obtenção de valor.

- Alavancagem do valor através da interação e troca de idéias a respeito das capacidades ociosas.

- Focalização no fluxo e intercâmbio da "transparência" das habilidades da organização através da criação de um bufê de conhecimentos, onde os tomadores de decisão podem optar em que precisam ser mais produtivos.

- Capitalização do processo através da divulgação, codificação, reciclagem e intercâmbio dos componentes.

\subsubsection{Modelo Quantum}

O modelo Quantum foi descrito em meados da década passada por Steven M. Hronec, sócio da empresa de consultoria Arthur Andersen, no livro nomeado Sinais Vitais, traçando uma analogia entre os sistemas da empresa e os sistemas do corpo humano.

Hronec (1994) considera que as medidas de desempenho são como os "sinais vitais" da organização, informando aos colaboradores o que estão fazendo, como eles estão se saindo e se estão agindo como parte do todo, a partir da associação da medida de desempenho com a estratégia da organização, de forma a todos os colaboradores usarem as mesmas definições.

Podem-se citar os seguintes benefícios das medidas de desempenho:

- Satisfação dos Clientes.

- Monitoramento do Progresso - A partir das medidas certas de desempenho torna-se possível a melhoria de processos e de forma contínua. 
- Benchmarking de processos e atividades - Fornece informações de modo a focalizar os melhores processos e comparar empresas (melhores práticas).

- Gerando mudança - As medidas corretas de desempenho auxiliam as empresas a realizar as mudanças necessárias com sucesso, pois elas rompem as barreiras e em muitos casos as evitam por definirem e recompensarem o novo comportamento das pessoas.

As melhores medidas de desempenho equilibram as operações da empresa interligando estratégias e processos. Medidas de desempenho podem ser divididas em dois tipos: medidas de desempenho do processo e medidas de desempenho do output. As mesmas devem ser definidas em forma de cascata associando a missão, estratégia, metas e processos dentro da organização, e devem ser avaliadas a partir de uma visão horizontal.

O modelo Quantum divide-se em três dimensões de medidas de desempenho, apresentadas em seguida, onde a "excelência" é definida pela parte interessada: cliente define para a dimensão qualidade; Administração define para o tempo e, por fim, os acionistas e a administração definem para a dimensão custo.

- Qualidade - Posiciona a "excelência" do produto ou serviço.

- Tempo - Posiciona a "excelência" do processo.

- Custo - Quantifica o lado econômico da "excelência".

As dimensões acima se inter-relacionam, assim quando os clientes recebem produtos de alta qualidade, atendendo ou excedendo suas expectativas, a um custo razoável ou baixo eles recebem um alto valor. Ou seja, a relação de custo e qualidade corresponde a valor para o cliente. 
De outro modo, quando recebem um produto ou serviço de alta qualidade que atenda ou exceda suas expectativas, muito rápido, crêem estar recebendo um alto nível de serviço.

Assim sendo a relação entre as dimensões de qualidade e de tempo é chamada "serviço". O desempenho Quantum é o nível de realização que vai otimizar o valor e o serviço de uma empresa para seus interessados,sendo que esta otimização deve ser geral e não de apenas um departamento, função ou fator e também de todas as três dimensões, custo, tempo e qualidade simultaneamente. O modelo Quantum é apresentado esquematicamente na Figura 7.

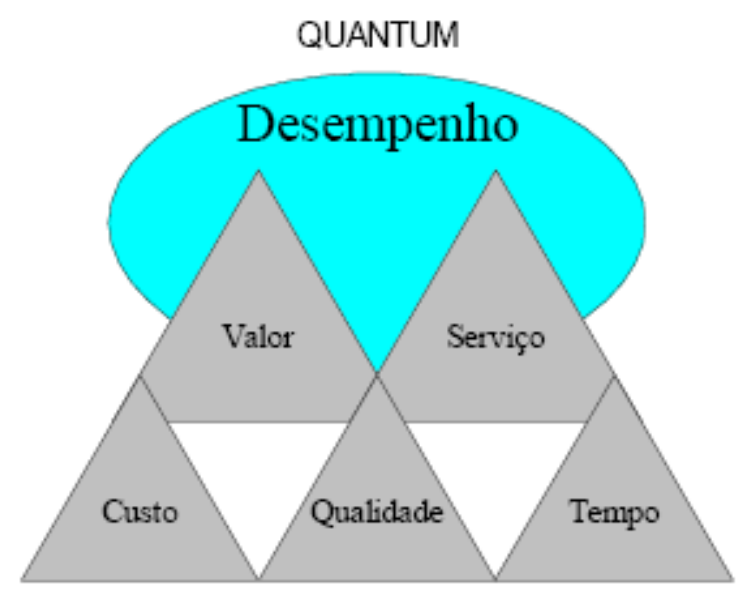

Figura 7 - Relacionamento das dimensões do modelo Quantum Fonte: adaptado de Hronec (1994)

O Modelo Quantum segue os três níveis de mobilização das medidas de desempenho do modelo Rummler \& Brache (ver Tabela 1); Organização, processo e humano (trabalho/executor) e alinha os mesmos com as três dimensões de medição de desempenho; Qualidade, custo e tempo.

- Nível Organização - Empresas estão tradicionalmente organizadas funcionalmente e a medição neste nível é orientada para o output e após o fato ocorrido. 
- Nível Processo - Os processos permeiam as estruturas funcionais e são eles que atendem as necessidades dos clientes. A medição neste nível é intermediária e orientada para o processo.

- Nível de Pessoas - Dentro das organizações, processos e funções. A medição neste nível é acionável e imediata.

\begin{tabular}{l|l|l|l}
\hline & \multicolumn{1}{|c|}{ Custo } & \multicolumn{1}{c}{ Qualidade } & \multicolumn{1}{c}{ tempo } \\
\hline Organização & -Financeiro. & -Empatia & -Velocidade \\
& -Operacional. & -Produtividade & -Flexibilidade \\
& -Estratégia. & $\begin{array}{l}\text {-Confiabilidade } \\
\text {-Credibilidade }\end{array}$ & $\begin{array}{l}\text {-Responsividade } \\
\text {-Maleabilidade }\end{array}$ \\
& & - Competência & \\
\hline Processo & - "Inputs" & -Conformidade & -Velocidade \\
& - Atividades & -Produtividade & -Flexibilidade \\
\hline Pessoas & -Remuneração & -Confiabilidade & -Responsividade \\
& - -Desenvolvimento & -Credibilidade & -Maleabilidade \\
& - -Motivação & -Competência & \\
\hline
\end{tabular}

Tabela 1 - Matriz Quantum de medição de desempenho (detalhada)

Fonte: adaptado de Hronec (1994)

A operacionalização do modelo Quantum se subdivide em quatro grandes etapas:

\subsubsection{Geradores do Modelo Quantum de Medição de Desempenho}

O modelo começa com a estratégia, a qual deriva de três fontes: liderança, interessados e melhores práticas. A mesma se precipita por toda a empresa através das medidas de desempenho, mantendo o foco da empresa no que é importante. Segundo Hronec (1994) as empresas devem focalizar no pensamento estratégico, um processo dinâmico que continuamente revê a missão, estratégias e operações sob os olhos dos clientes a forças do mercado. Uma maneira de garantir que o pensamento estratégico (ao invés do planejamento estratégico) seja utilizado é desenvolver e utilizar 
indicadores de desempenho, balanceando custo, qualidade e tempo para guiar o comportamento organizacional.

- Interessados - Indivíduos, grupos ou organizações afetadas pelos processos produtos e serviços. Ao desenvolver a estratégia, a administração deve identificar os grupos de interessados e entender suas expectativas e desejos concomitantemente.

- Melhores Práticas - São as melhores maneiras de se executar os processos. $\mathrm{Na}$ definição da estratégia devem ser levadas em conta as melhores práticas para os executivos saberem o que suas organizações podem fazer. As melhores práticas provocam a ruptura entre a organização e seu paradigma ajuda a definir alvos, provocando melhorias de até $300 \%$ quando feitas externamente e estabelecem um modelo para mudança, economizando tempo e dinheiro encurtando a curva de aprendizagem.

- Liderança - Considerando que as medidas de desempenho orientam a organização é importante que a liderança direcione o sistema de gestão de desempenho. O modelo proposto por Hronec (1994) trabalha com três fases: conscientização da liderança, aceitação e por fim domínio pela liderança.

\subsubsection{Facilitadores da Implementação do Modelo}

O modelo define quatro facilitadores: comunicação, treinamento, recompensas e "benchmarking" que auxiliam a organização a desenvolver, implementar e utilizar novas medidas de desempenho.

Entende-se por comunicação no modelo o processo de troca de idéias dentro da organização. $O$ treinamento ajuda a ressaltar as habilidades gerenciais, devendo ser um processo contínuo. 
A definição para recompensas no modelo é: algo dado em troca de serviço ou realização, não necessariamente dinheiro. E por fim o "benchmarking" que permite as empresas avaliarem a sua posição "como esta" e sua posição "como deve ser". O três benefícios do "benchmarking" são fornecer uma diretriz para entender e exceder os desejos do cliente, estabelecer metas focalizadas no cliente e crescer a conscientização em relação às melhores práticas.

Para implementar novas estratégias, as pessoas precisaram trabalhar diferentemente e deveriam ser medidas diferentemente. Assim, a empresa lidere precisarão revisar e comunicar suas estruturas de recompensas para suportar estas novas medidas de performance (HRONEC, 1994).

\subsubsection{Processo do Modelo de Desempenho Quantum e Melhoria Contínua}

- Meta - A primeira etapa do processo é a definição da meta para as dimensões custo, qualidade e tempo, para tanto se utiliza a ferramenta "benchmarking" em três diferentes visões; interno, competitivo e classe mundial e uma técnica de "benchmarking" chamada custeio-alvo baseada no custo máximo de produção que permite o retorno esperado pela organização.

- Processos críticos - O processo de desenvolvimento de medidas de desempenho inicia-se pela estratégia da organização ou unidade de negócio, e em cascata de forma descendente estabelecem-se as metas e a identificação dos processos críticos. É importante a identificação dos processos críticos pois focaliza todos naquilo que é importante para a organização. Os processos críticos são aqueles que têm impacto direto sob a consecução das estratégias e metas. Para estes processos definem-se metas simultâneas de custo, qualidade e tempo sob o enfoque do cliente.

- Medidas de desempenho de "output" - Os relatórios financeiros tradicionais são tipicamente as medidas de "output", podemos citar contabilidade, orçamento e 
sistema orçamentário. As Medidas de desempenho de "output" devem abordar o custo, qualidade e tempo, de modo a administrar as expectativas dos clientes (qualidade), as demandas sobre seus processos (tempo) e a economia da organização (custo) e tudo ao mesmo tempo.

- Atividades chaves - A principal ferramenta para se entender os processos é através do seu mapeamento, a partir dele se identificar quando, onde e como melhorar os processos. A partir do mapeamento se identifica a atividade chave que é a etapa crucial para a integridade do processo e o seu output. O número de atividade chave deve variar de duas a seis por processo.

- Medidas de desempenho do Processo - Após a determinação das atividades chaves devem ser desenvolvidas as medidas de desempenho. As mesmas relatam as atividades do processo e motivam as pessoas a controlá-lo. Estas devem monitorar os processos, prever e evitar problemas, melhorar continuamente os processos, verificar a seleção das atividades chaves e finalmente motivar as pessoas.

- Implementação e melhoria contínua - Problemas que podem ser encontrados na implementação: As pessoas do processo não julgam que as medidas de desempenho selecionadas sejam importantes. As próprias medidas de desempenho podem não ser confiáveis ou as mesmas serem usadas para criticar os colaboradores e não para a melhoria dos processos. Há também às medidas de desempenho em excesso que não são necessárias na execução das tarefas exigidas e por fim que os colaboradores, em função do entusiasmo inicial, podem pensar que mais é melhor e criar muitas medidas.

- A implementação é baseada em seis etapas: validar a rotina dos relatórios, obterem o endosso da administração para as medidas de output, a freqüência que é necessária as informações e qual o motivo da necessidade das informações, submeter o plano a todos os interessados, captar, monitorar, 
analisar relatar as medidas de desempenho, avaliar a efetividade das medidas de desempenho e finalmente, a melhoria contínua.

\subsubsection{Rummler \& Brache}

Para Rummler \& Brache (1994) a visão de sistemas de uma organização é o ponto de partida para a criação e gerenciamento de organizações que respondam de modo eficiente à realidade atual de concorrência acirrada e de expectativa de mutação dos clientes. Para lidar com essa realidade considera-se que a variável-chave na habilidade da organização em adaptar-se de forma eficiente e rápida é o seu gerenciamento.

O modelo considera que o "ecossistema" interno e externo de uma organização (Clientes, produtos e serviços, sistemas de recompensa, tecnologia, estrutura da organização etc.) está conectado, de modo que para aprimorar o desempenho individual e da organização deve-se reconhecer a interdependência entre as variáveis de desempenho.

Os autores afirmam que a forma de compreender as variáveis acima é através da aplicação da visão dos sistemas nos três níveis de desempenho: Organização, Processo e Trabalhador/Executor.

O nível da organização trabalha o relacionamento da empresa com o mercado e a configuração básica das principais funções da organização e contém as variáveis de desempenho como estratégias, objetivos e medidas da organização. O nível de processos apresenta o fluxo de trabalho, como ele é feito, focando além das fronteiras funcionais que compõem o organograma.

Por fim, temos o Nível de Trabalho/Executor. Os autores propõem que os

processos produzem as saídas das organizações e os mesmos são executados e gerenciados por pessoas que executam trabalhos variados. Segundo Rummler \& 
Brache (1994) pode-se afirmar que uma organização é tão boa quanto forem os seus processos.

Os três níveis de desempenho propostos acima constituem uma dimensão do modelo de Rummler \& Brache, a outra dimensão proposta é compreendida de três fatores, chamados Necessidades de Desempenho que vão determinar a eficiência de cada nível: Objetivos, Projetos, Gerenciamento. As nove variáveis de desempenho resultantes podem ser observadas na Tabela 2.

\begin{tabular}{l|c|c|c}
\hline Nivel de Organização & Objetivos & Projeto & Gerenciamento \\
\hline Nivel de Processo & Objetivos da Organização & Projeto da Organização & $\begin{array}{c}\text { Gerenciamento da } \\
\text { Organização }\end{array}$ \\
\hline $\begin{array}{l}\text { Nivel de trabalho/ } \\
\text { executor }\end{array}$ & $\begin{array}{c}\text { Objetivos do Trabalho } \\
\text { /Executor }\end{array}$ & Projeto do processo & $\begin{array}{c}\text { Gerenciamento do } \\
\text { Processo }\end{array}$ \\
\hline
\end{tabular}

Tabela 2 - As nove Variáveis de desempenho

Fonte: Adaptado de Rummler \& Brache (1994)

Os objetivos definem os padrões que refletem quais são as expectativas do cliente quanto à qualidade, à quantidade, à disponibilidade e ao custo do produto ou serviço, o Projeto define quais são os componentes necessários e de que maneira os mesmos precisam configurados de forma a permitir que os objetivos sejam atingidos e por fim, o gerenciamento define quais são as práticas que vão garantir que os objetivos sejam atuais e que vão ser atingidos.

A estrutura de três níveis (conforme Tabela 3) é usada como; um instrumento para diagnóstico e eliminação do desempenho deficiente, um motor para o aperfeiçoamento contínuo dos sistemas, um mapa para nortear a organização em uma nova direção, um projeto para desenvolvimento de uma nova operação. 


\begin{tabular}{|c|c|c|c|}
\hline & Objetivos & Projetos & Gerenciamento \\
\hline 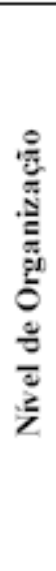 & $\begin{array}{l}\text { A estratégia /direção da } \\
\text { organização foi articulada e } \\
\text { comunicada? } \\
\text { Esta estratégia faz sentido em } \\
\text { termos de ameaças e } \\
\text { oportunidades externas e de } \\
\text { pontos fortes e fracos } \\
\text { internos? } \\
\text { Dada esta estratégia, foram } \\
\text { determinadas e comunicadas } \\
\text { as devidas saidas da } \\
\text { organização. bem como, o } \\
\text { nivel de desempenho esperado } \\
\text { de cada saida? }\end{array}$ & $\begin{array}{l}\text { Todas as funções relevantes } \\
\text { estão posicionadas? } \\
\text { Existem funções } \\
\text { desnecessárias? } \\
\text { O fluxo atual de entradas e } \\
\text { saidas entre as funções é } \\
\text { adequado? } \\
\text { A estrutura formal da } \\
\text { organização apóia a estratégia } \\
\text { e melhora a eficiência do } \\
\text { sistema? }\end{array}$ & $\begin{array}{l}\text { Foram estabelecidos objetivos de } \\
\text { função adequados? } \\
\text { O desempenho relevante é medido? } \\
\text { Os recursos são adequadamente } \\
\text { alocados? } \\
\text { As interfaces entre as funções estão } \\
\text { sendo gerenciadas? }\end{array}$ \\
\hline 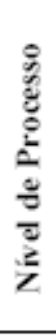 & $\begin{array}{l}\text { Os objetivos dos processos } \\
\text { chaves estão ligados aos } \\
\text { requisitos da organização e do } \\
\text { cliente? }\end{array}$ & $\begin{array}{l}\text { Este é o processo mais } \\
\text { eficiente /efetivo para atingir } \\
\text { os objetivos do projeto? }\end{array}$ & $\begin{array}{l}\text { Foram estabelecidos os devidos sub- } \\
\text { objetivos do processo? } \\
\text { O desempenho do processo é } \\
\text { gerenciado? } \\
\text { São alocados recursos suficientes para } \\
\text { cada processo? } \\
\text { As interfaces entre as etapas do } \\
\text { processo estão sendo gerenciadas? }\end{array}$ \\
\hline 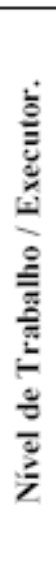 & $\begin{array}{l}\text { As saidas e os padrões de } \\
\text { trabalho estão ligados aos } \\
\text { requisitos do processo (e } \\
\text { conseqüente aos requisitos da } \\
\text { organização e do cliente)? }\end{array}$ & $\begin{array}{l}\text { Os requisitos do processo se } \\
\text { refletem nos respectivos } \\
\text { trabalhos? } \\
\text { As etapas do trabalho têm uma } \\
\text { sequência lógica? } \\
\text { Foram desenvolvidos } \\
\text { procedimentos e políticas de } \\
\text { apoio? } \\
\text { O ambiente de trabalho faz } \\
\text { sentido em termos } \\
\text { econômicos? }\end{array}$ & $\begin{array}{l}\text { Os executores compreendem os } \\
\text { objetivos do trabalho? } \\
\text { Os executores têm recursos suficientes, } \\
\text { sinais e prioridades claras e um projeto } \\
\text { lógico? } \\
\text { Os executores são recompensados } \\
\text { quando atingem os Objetivos do } \\
\text { trabalho? } \\
\text { Os executores têm conhecimento } \\
\text { /habilidades devidas para atingir os } \\
\text { Objetivos do trabalho? } \\
\text { Caso as respostas acima sejam sim, os } \\
\text { executores têm capacidade para atingir } \\
\text { os objetivos do trabalho? }\end{array}$ \\
\hline
\end{tabular}

Tabela 3 - As nove variáveis de desempenho com perguntas Fonte: adaptado de Rummler \& Brache (1994)

O primeiro passo, para o desdobramento dos objetivos estratégicos em ações estratégicas se dá a partir do mapa de relacionamentos no nível da organização que descreve relações entre cliente-fornecedor, funções que formam o negócio, tornando visíveis as entradas e saídas entre as funções. A partir desta análise identificam-se os "fios desligados", isto é, entradas ou saídas inexistentes, desnecessárias, confusas ou mal direcionadas. A partir desta análise é elaborado o mapa de relacionamento ideal. Após, no nível de processos identificam-se os processos críticos e elabora-se o mapa 
de processos atual. Elabora-se o mapa de processos Ideal a partir da análise dos fios desligados e finalmente estabelece-se um plano de ação para migrar do processo atual para o ideal.

No sentido do sistema da organização ser efetivamente gerenciado torna-se necessário: medidas sólidas que garantam o monitoramento das coisas corretas, um sistema de medição total, e não uma coleção de medidas não-relacionadas e finalmente um processo de desempenho que converta os do sistema de medição em ação inteligente. O modelo propõe:

Desenvolvimento de medidas sólidas - No sentido de medir o desempenho, ou seja, a saída, deve-se seguir a seguinte seqüência:

- Identificar as saídas mais significativas dos três níveis (Organização, Processo, Trabalho).

- Identificar as "dimensões críticas" de desempenho: Qualidade (Precisão,Facilidade de uso,Confiabilidade, Facilidade de Conserto e Aparência), Produtividade (Quantidade, Índice, Cumprimento de Prazo) e por fim, Custo (Trabalho, Materiais e Despesas Gerais). As mesmas originam-se das necessidades dos clientes internos e externos e das necessidades financeiras do negócio.

- Estabelecer medidas para cada dimensão crítica.

- Desenvolver objetivos, ou padrões, para cada medida, traduzindo um nível específico de expectativa de desempenho.

Estas medidas devem ser: ( $I$ ) Dirigidas aos Clientes, contrastando com a prática freqüente de estabelecer indicadores baseados na facilidade de medição; (ii) Voltadas para o cliente, deste modo, as saídas, dimensões críticas e os objetivos são determinados todos pelos requisitos dos clientes, e por fim; (iii) que a maioria das 
saídas deve ser multidimensionais, isto é, devem atender varias dimensões criticas ao mesmo tempo.

\subsubsection{Sink \& Tuttle}

Este modelo propõe quatro áreas de melhoria de performance para responder com êxito aos novos desafios. São elas; (I) Planejamento para melhoria da performance; (ii) Medição e avaliação da performance; (iii) Melhoria e controle da performance e (iv) Sistemas de apoio cultural.

Conforme Sink \& Tuttle (1993) o processo de planejamento estratégico é tão importante quanto o próprio plano e deve: (I) Envolver mais pessoas dentro da organização; (ii) Ser mais estruturado, porém menos formal; (iii) Enfocar o plano e o processo; (iv) Comandar o orçamento; ( $v$ ) Criar um maior equilíbrio entre marketing, finanças e operações; (Vi) Ampliar os horizontes do planejamento; (vii) Vincular mais eficazmente o planejamento das ações e a implantação eficaz.

O planejamento da melhoria da performance é uma importante responsabilidade de todos os colaboradores da organização. O mesmo exigirá que todas as pessoas, em todos os níveis da organização, pensem, controlem e executem. O processo de planejamento para melhoria de performance é projetado para motivar o controle e a realização das metas de longo prazo, como: Sobreviver, Crescer, Competir e melhorar o nível de performance. 


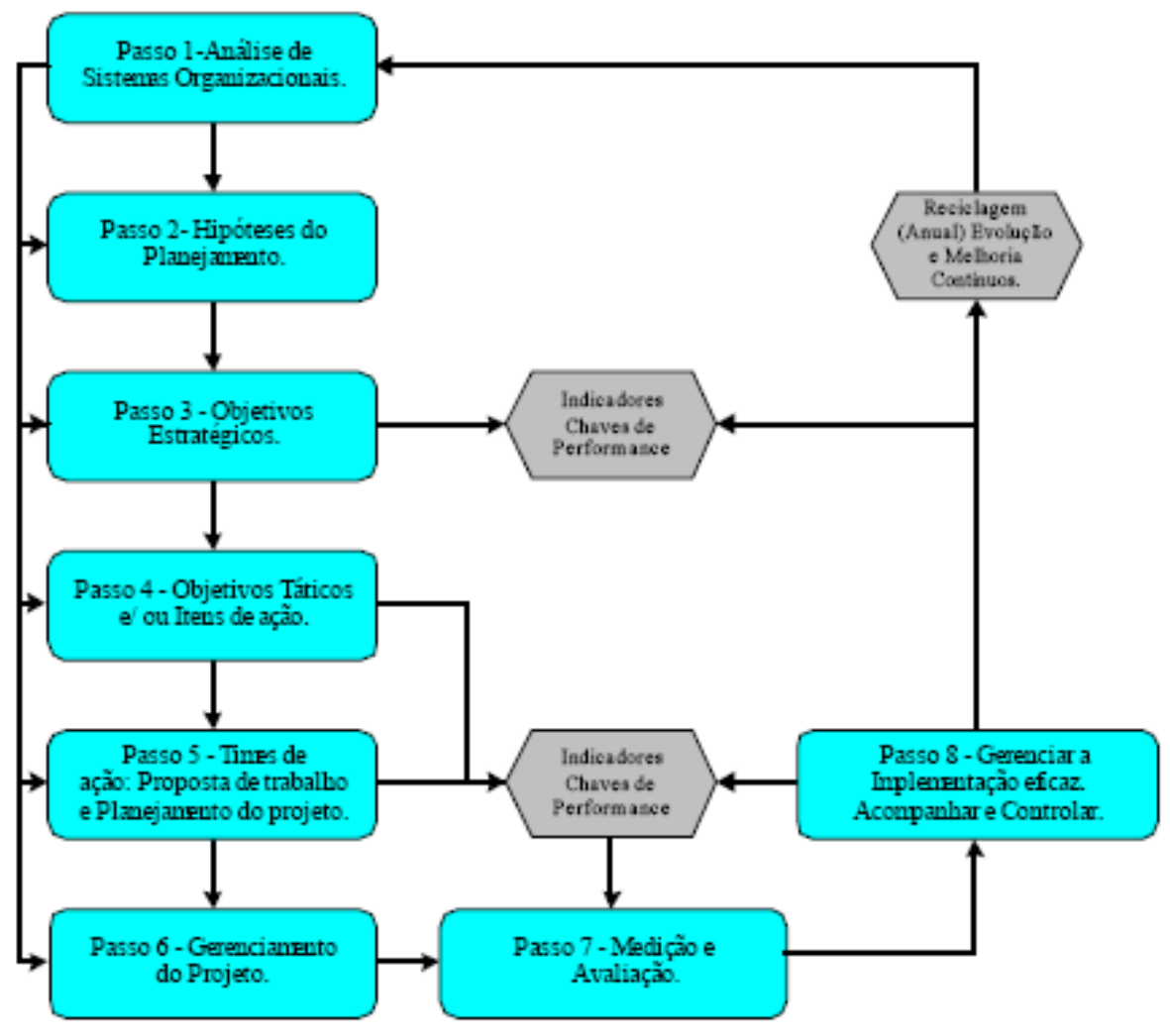

Figura 8 - Processo de Planejamento de Performance

Fonte: adaptado de Sink \& Tuttle (1993)

Os autores propõem duas estratégias para energizar a melhoria de performance, a primeira é a estratégia movida pela medição e a segunda consiste na estratégia baseada na visão compartilhada de uma organização do futuro, onde esta visão é a grande fonte de força e energia e onde os números vêm após a visão.

No modelo Sink \& Tuttle a medição está separada da avaliação, o processo de medição não é baseado em valor, e é o processo onde se decide o que medir fazendose a coleta e a análise dos dados. Em contrapartida, é no processo de avaliação que se estabelecem os padrões, especificações, requisitos, valores e julgamentos, determinando o grau no qual a performance satisfaz as necessidades e ou expectativas dos clientes. 
O modelo apresenta que a performance de um sistema organizacional é função de um complexo inter-relacionamento de sete critérios de performance, sendo eles:

- Eficácia - Critério de performance que verifica a realização efetiva das coisas certas no momento certo e dentro dos requisitos de qualidade esperados. A medida é uma relação entre a saída obtida e a saída esperada.

- Eficiência - Medida de performance que compara através de uma relação o consumo previsto pelo consumo efetivamente realizado.

- Qualidade - A medição da qualidade está difusa em todo o processo, pois tratase de um critério importante em todos os estágios do ciclo de vida do fluxo de recursos e gerenciamento do sistema. No sentido de melhor definir o conceito de qualidade, o melhor é descrevê-la nos seis pontos de verificação da Qualidade, e que também pode ser entendido pela Figura

- Ponto da Verificação da Qualidade 1 - Seleção e gerenciamento de sistemas a montante, como fornecedores, vendedores etc., e está ligado a projeto e desenvolvimento de produtos e serviços, comunicação de especificações, necessidades e requisitos.

- Ponto da Verificação da Qualidade 2 - Verifica o que o sistema organizacional está recebendo a montante e compara com aquilo que necessita, quer e merece.

- Ponto da Verificação da Qualidade 3 - Gerenciamento da qualidade total, enfocando a criação da qualidade no produto e no serviço.

- Ponto da Verificação da Qualidade 4 - Este ponto foca na garantia de o que está sendo produzido pelo sistema organizacional está efetivamente satisfazendo as especificações e requisitos estabelecidos. 
- Ponto da Verificação da Qualidade 5 - Avalia os sistemas a jusante e está ligada a compreensão detalhada e pró-ativa do que o cliente quer, precisam, esperam e exigem, e de que modo eles estão reagindo com relação à entrega dos bens e serviços fornecidos pelo sistema organizacional.

- Ponto da Verificação da Qualidade 6 - É o ponto de coordenação e gerencial global do processo.

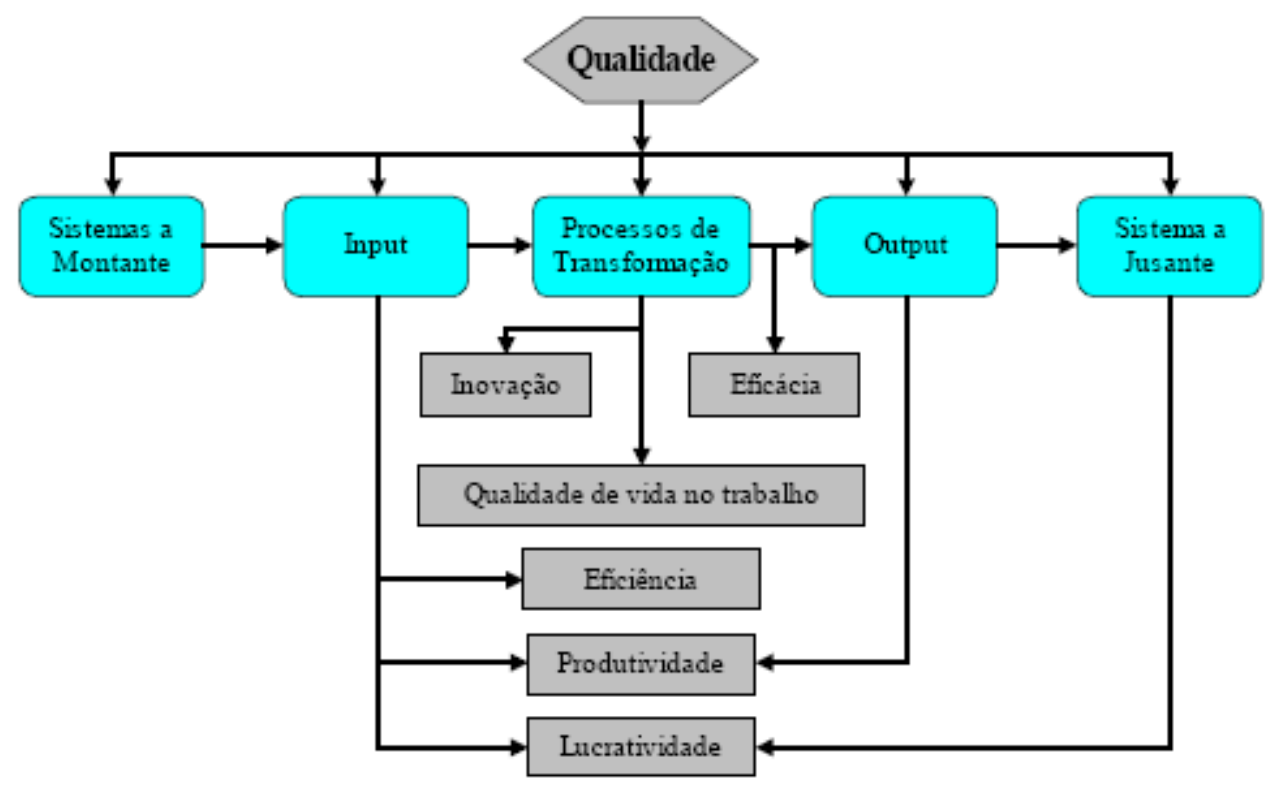

Figura 9 - O sistema organizacional e os sete critérios de performance Fonte: adaptado de Sink \& Tuttle (1993)

- Produtividade - Estabelece a relação entre o que foi gerado por um sistema organizacional e o que entra neste sistema.

- Qualidade de Vida no Trabalho (QVT) - Como as pessoas respondem afetivamente a certos estímulos do sistema organizacional, tais como: Remuneração, condições de trabalho, cultura, liderança, relacionamento com os colegas, "feedback", tomada de decisões etc; 
- Inovação - Processo de modificar o que está sendo feito, ou mesmo o modo como estão sendo feitas as coisas, estruturas, tecnologias, produtos, serviços, métodos, procedimentos, políticas etc. De modo a reagir com resultado frente a pressões, oportunidades, desafios e ameaças externas e internas.

- Lucratividade - Medida ou conjunto de medidas que relacionam receita e custo, no caso de centro de lucros e medidas da relação entre orçamento, metas, entregas e prazos combinados, e custos, cumprimentos e prazos efetivos quando for o caso de ser um centro de custos.

O modelo apregoa que se forem bem definidas as coisas certas a serem feitas (Eficácia), com uso dos recursos corretos (Eficiência) e com os produtos, serviços e processos satisfazendo os requisitos (Qualidade) a Produtividade virá como conseqüência.

Os autores também consideram os critérios de Qualidade de vida no trabalho e Inovação como variáveis moderadoras na equação, podendo aumentar a performance ou diminuí-la a partir da moderação da relação entre produtividade e lucratividade. A longo prazo uma má performance nas áreas de qualidade de vida no trabalho e Inovação freqüentemente significa prenúncio de fracasso para a empresa. Em contrapartida, os resultados almejados de longo prazo tais como, sobrevivência, crescimento e melhoria e excelência são obtidos a partir da ótica da produtividade dominando a lucratividade (Equação da Esquerda para direita).

$\mathrm{Na}$ maior parte das empresas existe uma forte propensão de que o orçamento dirija o plano das mesmas. Haja vista, a auditória e o orçamento serem muito poderosos na maior parte das empresas, forçando que as equipes gerenciais dirijam a equação da direita para esquerda no processo de gestão. 


\subsubsection{Balanced Scorecard (BSC)}

Em torno de 1990, empresas francesas usavam um sistema de gestão estratégico chamado "tableau of board" o qual traduzindo literalmente para o português significa "Painel de Instrumentos". O sistema de gestão consistia na tomada de decisões a partir da compreensão das mensagens obtidas dos indicadores chaves de performance, tal como os pilotos tomam a partir da leitura do painel de instrumentos para garantir o controle e a segurança do avião durante o vôo. No "tableau of board", o sucesso para atingir os objetivos requeria comprometimento gerencial e liderança na atenção às forças chaves e variáveis através do desenvolvimento dos planos de ação (BALANCED SCORECARD, 2004).

À semelhança do "tableau of board", por volta de 1980, as maiores corporações como IBM, HP and Hershey Food Corp., começaram a aplicar o "Benchmarking" de maneira a identificar pontos fortes e fracos que poderiam auxiliá-las a ganhar ou manter sua competitividade. Estes pontos incluem satisfação do consumidor, ciclo de vida do produto e produtividade do colaborador sendo que estes conceitos foram refinados e simplificados por Robert Kaplan da Harvard Business School, Boston, e David Norton, presidente do Renaissance Strategy Group no conceito "Balanced Scorecard" (WESTON, 2003).

O embrião do modelo de gestão a partir do "Balanced Scorecard" começou no início dos anos 90 a partir de um estudo patrocinado pela consultoria KPMG. Este estudo, chamado "Measuring the performance in the organization of the future" durou aproximadamente 1 ano envolvendo diversas empresas. O mesmo apoiou-se na crença de que os métodos tradicionais de gestão baseados em indicadores financeiros e contábeis tornaram-se obsoletos, pois se baseavam em dados consolidados, não apoiando a empresa na geração de valor futuro.

Dentre as empresas que participavam do projeto, uma delas, a Analog Devides havia desenvolvido um sistema de avaliação baseado em um "Scorecard" que incorporava além das medidas financeiras tradicionais, outras medidas de desempenho 
que envolvia indicadores operacionais. A partir da constatação pelo grupo, de que a adoção de um "scorecard" multidimensional seria mais promissor, amplia-se o escopo inicial e surgem as quatro perspectivas a saber: Financeira, Cliente, Interna e Aprendizado.

A partir da ampliação do escopo o "Scorecard" passa a chamar-se "Balanced Scorecard" refletindo o equilíbrio entre os objetivos de curto e médio prazo, medidas financeiras e não financeiras, indicadores de tendência e perspectivas internas e externas.

A conclusão do estudo acima foi sintetizada no artigo "The Balanced ScorecardMeasures That Drive Performance" (KAPLAN \& NORTON, 1992). Após foi descrita a importância da escolha de medidas de performance baseadas realmente nos processos estratégicos no artigo "Putting the Balanced Scorecard to Work" (KAPLAN \& NORTON, 1993). Por fim foram reunidas as principais evoluções ocorridas a partir das primeiras aplicações do "Balanced Scorecard" no artigo "Using the Balanced Scorecard as a Strategy Management System" (KAPLAN \& NORTON, 1996).

O Balanced Scorecard pode ser descrito como um sistema gerencial que traduz a missão e a estratégia da empresa eu um conjunto de medidas de desempenho abrangentes que será a base para um sistema de Medição e Gestão (SILVA, 2002).

Shih-jen \& McKay (2002) ampliam o conceito definindo o Balanced Scorecard como um sistema de medição de performance e gestão estratégica que traduz a missão e a estratégia em um conjunto balanceado de medidas integradas de performance, e a partir destas medidas, irá prover um conjunto completo do progresso da organização em direção a sua missão e objetivos, sendo que o Balanced Scorecard também pode ser usado como uma ferramenta de motivação e feedback de performance.

O BSC consiste em um sistema gerencial flexível para selecionar e mostrar medições de "indicadores chaves" sobre a empresa em um formato de fácil leitura. Esse 
sistema gerencial carrega em si alguns fatores que o colocam à frente de outros sistemas de aplicação similar. Primeiramente, o BSC permite aos principais líderes da empresa visualizar de forma rápida e eficaz como está se desenvolvendo o trabalho que deverá consolidar o que foi determinado pelo planejamento estratégico. Em segundo lugar, o BSC diferencia-se dos relatórios financeiros tradicionais que olhavam para trás refletindo apenas gastos incorridos e receitas auferidas. Tais relatórios, não medem a criação nem a destruição de valor econômicos futuro. Em contrapartida o BSC é um recurso que permite às empresas obter uma visão de sua situação futura.

É um conjunto resumido de medidas de performance que propicia uma visão da empresa em um único relatório gerencial. Conforme uma pesquisa realizada em 2001 sobre ferramentas de gestão, a alta direção comumente utiliza 3 ferramentas quando desenvolve o "Business Plan" e avalia a performance na empresa: Planejamento estratégico é utilizado por $80 \%$ dos gerentes, Missão e Visão por $76 \%$ e Benchmarking por $68 \%$ (WESTON, 2003).

Berton (2003) assim como Weston (2003) acima, também traça um paralelo entre a ferramenta do BSC e a do Planejamento estratégico ponderando que o mesmo trabalha com o estabelecimento de metas e com construção de indicadores capazes de proporcionar a alta direção e gestão o acompanhamento das ações da empresa e resultados obtidos, enquanto que a ferramenta do Planejamento estratégico trabalha com estabelecimento de objetivos e metas, e com variáveis passíveis de controle pela organização. Neste caso, não constitui nenhuma novidade a utilização do BSC em relação à ferramenta Planejamento estratégico. O diferencial do BSC é que o mesmo simplifica o processo de estabelecimento de metas e seu controle e, de modo essencial, a comunicação clara e transparente dos objetivos estabelecidos bem como o equilíbrio entre os setores da empresa (BERTON, 1998).

O Balanced Scorecard preserva as medidas financeiras tradicionais adicionando medidas dos vetores que impulsionam o desempenho futuro. Os objetivos e medidas utilizadas pelo BSC advêm da visão e estratégias da empresa. Estes objetivos e 
medidas se concentram no desempenho organizacional sob quatro perspectivas, que formam sua estrutura, financeira, interna, clientes e aprendizagem e crescimento (KAPLAN \& NORTON, 1997).

O Balanced Scorecard proporciona meios para ligar a estratégia de diferentes unidades de operação dentro de uma organização considerando a missão e a visão, mas o mais importante aspecto é que ele permite à organização ligar uma estratégia de longo prazo com ações de curto prazo (CAMERON, 2002).

\subsubsection{Objetivos do Balanced Scorecard}

O BSC preenche a lacuna dos principais sistemas gerenciais, ou seja, a falta de um processo sistemático para implementar e acompanhar a estratégia.

A construção dos processos gerenciais a partir do "Scorecard" propicia o alinhamento da organização e focaliza a mesma na implementação da estratégia a longo prazo. Além disso, podemos também considerar os seguintes objetivos:

- Esclarecer e traduzir a Visão e a Estratégia;

- Comunicar e associar objetivos e medidas estratégicas;

- Planejar, estabelecer metas e alinhar iniciativas estratégicas;

- Melhorar o "feedback" e o aprendizado estratégico. 

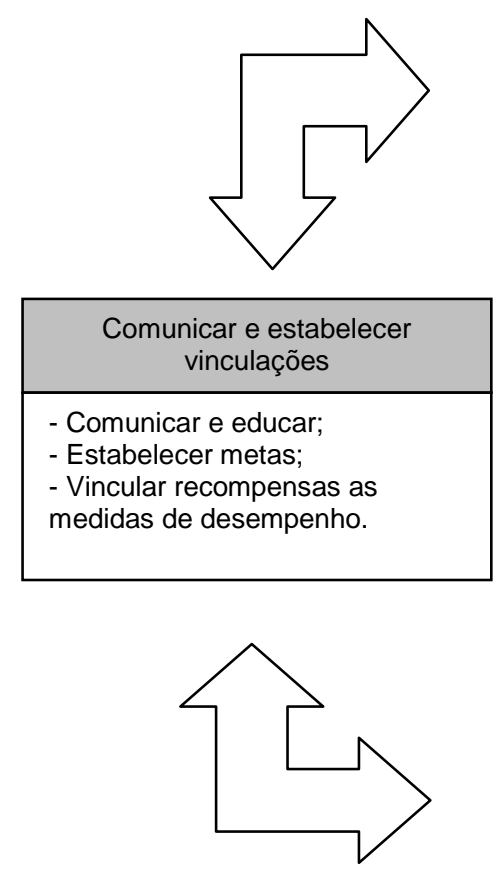
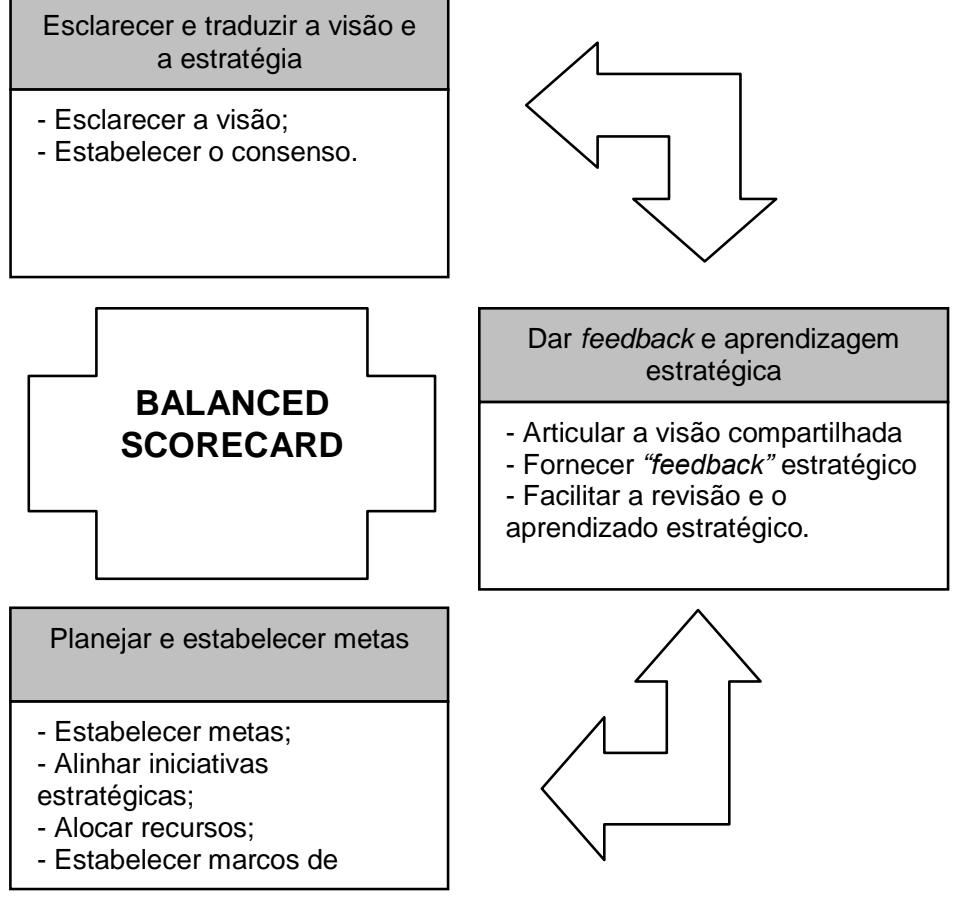

Figura 10 - Relacionamento entre os objetivos do BSC

Fonte: adaptado de Kaplan \& Norton (1997)

O primeiro passo do BSC consiste em reunir a alta direção para traduzir a estratégia da empresa ou a unidade de negócio em objetivos estratégicos específicos. O estabelecimento de metas financeiras deve priorizar a receita e o crescimento de mercado, lucratividade ou geração de fluxo de caixa.

Após o estabelecer as metas financeiras e as do cliente, a organização deve estabelecer os objetivos e medidas para seus processos internos, e, concluída esta etapa parte-se para estabelecer as metas de aprendizado e crescimento, onde se estabelecem os motivos para investimento significativos em reciclagem de funcionários, tecnologia e sistemas de informações (KAPLAN \& NORTON, 1997).

Em seguida, os objetivos e medidas estratégicas devem ser transmitidos para a empresa inteira através de e-mail , intranet, jornais internos, reuniões, cartazes e outras formas. A comunicação serve para apresentar aos colaboradores os objetivos estratégicos que devem ser alcançados de modo a viabilizar a Estratégia da empresa. 
O importante é que todos os funcionários estejam alinhados com estes objetivos, pois, a partir deste alinhamento e da sua compreensão, eles podem estabelecer metas locais que apóiem a estratégia global da unidade de negócios (KAPLAN \& NORTON, 1997).

A divulgação de forma ampla dos objetivos e metas estratégicas, dentro do escopo do Balanced Scorecard, propicia dois aspectos de vital importância para a gestão da organização: participação e comprometimento. Considerando que todos os colaboradores da organização conheçam os objetivos e medidas estratégicas, os mesmos têm oportunidade de opinar, discordar, concordar e sugerir mudanças gerando a participação interna. Esta participação fomenta o comprometimento natural das pessoas com os objetivos da organização (SILVA, 2002).

$\mathrm{Na}$ seqüência, a alta direção deve estabelecer metas para os objetivos estratégicos com 3 a 5 anos de antecedência visando à transformação da empresa, ou seja, as metas serão definidas de modo a propiciar uma descontinuidade no desempenho da unidade de negócio.

Para alcançar uma meta financeira ousada, metas de superação para os processos de atendimento dos clientes, processos internos e de aprendizagem e crescimento devem ser estabelecidos. Pode-se utilizar o benchmarking de modo a estabelecer referenciais de atuação e obtenção que incorporem as melhores práticas do mercado evitando que as metas internas pífias restrinjam a performance estratégica da unidade. Após a definição das metas, devem-se alinhar as iniciativas estratégicas para alcançar os objetivos estabelecidos através da reengenharia, melhoria contínua e processos de transformação (KAPLAN \& NORTON, 1997).

Esta fase focaliza a organização a quantificar os resultados pretendidos no longo prazo, identificando os mecanismos e recursos necessários para atingi-los. Referenciais de curto prazo, criados nesta fase, auxiliam na gestão do curso das ações e dos resultados parciais permitindo as aplicações de ações corretivas quando necessárias. É 
de vital importância estabelecer objetivos estratégicos claros, tangíveis e compreensíveis para todos os colaboradores de organização (SILVA, 2002).

Por fim, deve-se melhorar o "feedback" e o aprendizado estratégico, o que segundo Kaplan \& Norton é o processo mais inovador e importante de todo o scorecard, pois o mesmo permite à alta direção receber o feedback sobre sua estratégia e testar as hipóteses que a norteiam, possibilitando o monitoramento e ajuste da implementação da mesma e, caso necessário, a adoção de mudanças fundamentais na própria estratégia.

Este feedback é de suma importância para que os gestores possam verificar se as metas foram atingidas, mas também se as estratégias definidas continuam válidas, ou seja, se as premissas em que as estratégias foram baseadas continuam atualizadas. Podemos chamar este efeito de "aprendizado de circuito duplo", no qual os gestores recebem o feedback sobre o desempenho do processo com relação às metas acordadas e informações que propiciam o questionamento sobre se os pressupostos nos quais as metas foram definidas continuam válidos (SILVA, 2002).

Com estabelecimento de referenciais de curto prazo para medidas financeiras e não financeiras do BSC, pode-se avaliar minuciosamente mensalmente ou trimestralmente se determinada unidade de negócios está alcançando suas mentas em relação a clientes, processos internos e inovação. Estas metas terão impacto na expectativa de resultados futuros da organização propiciando que as revisões e atualizações deixem de analisar o passado para aprender sobre o futuro.

- Identificar e alinhar as iniciativas estratégicas.

- Propiciar revisões estratégicas periódicas e sistemáticas.

- Aprofundar o conhecimento da estratégia e aperfeiçoá-la através do feedback obtido do BSC. 
- Obter consenso em relação à estratégia.

- Comunicar e esclarecer a estratégia a toda à empresa.

- Propiciar o alinhamento das metas departamentais e pessoais à estratégia da empresa.

- Alinhar as metas de longo prazo e o orçamento da empresa aos objetivos estratégicos.

- Considerando o exposto o BSC torna-se a base para o gerenciamento das empresas (KAPLAN \& NORTON, 1997).

O BSC é representado por quatro diferentes perspectivas que representam as principais variáveis, as quais, em equilíbrio, garantem as condições de gestão nos processos de planejamento e controle das ações estratégicas (BERTON, 2003).

Pode-se considerar que a existência destas quatro perspectivas torna o BSC um sistema rígido, pois os objetivos geralmente transcendem as dimensões originais (REDI 2002; BONTIS, NICK, DRAGONETTI, JACOBSEN, 1999).

Deve-se considerar que estas quatro perspectivas tem-se revelado adequadas a vários tipos de empresas e mercados, mas conforme Kaplan \& Norton (1997) não devem ser vistas como uma camisa de força, pois se trata de um modelo, dependendo das circunstâncias do setor e da estratégia da unidade de negócios talvez seja necessário agregar uma ou mais perspectivas.

\subsubsection{Perspectivas Financeiras}

Conforme Silva (2002) as perspectivas financeiras são tradicionais em qualquer sistema gerencial, e no Balanced Scorecard aparecem as medidas financeiras. Elas são 
essenciais, pois demonstram a intenção, quando estabelecem os objetivos financeiros de longo prazo e propiciam a constatação da eficácia das estratégias e ações implementadas em chegar nos resultados esperados.

Para Kaplan \& Norton (2000) a definição da perspectiva financeira é o primeiro passo para montar o mapa estratégico da empresa, onde se busca aumentar o valor das ações para os acionistas (em empresas sem fins lucrativos ou governos são colocados os clientes e cidadãos - não financeiros no topo do seu mapa estratégico). Esta perspectiva se subdivide em duas diferentes estratégicas, crescimento do faturamento e aumento da produtividade. O crescimento do faturamento está relacionado ao ganho de novos mercados, novos produtos e novos clientes e ao aumentar do valor dos clientes atuais através do aprofundamento do relacionamento com os mesmos por meio da expansão das vendas. O ganho de produtividade está relacionado também a duas estratégias, otimizar a estrutura de custos da empresa reduzindo despesas diretas e indiretas e a partir da utilização mais eficaz dos ativos, reduzirem o custo de capital de giro e o custo fixo para um mesmo nível de operação. Clarke \& Tyler (2001) ponderam que além dos valores econômicos e de produtividade elencados acima devemos avaliar também o valor econômico agregado (EVA Economic Value Added).

Esta perspectiva, além de ser a primeira a ser definida, conforme exposto acima, exerce um duplo papel pois define o desempenho financeiro esperado da estratégia e também vai ser a base para os objetivos e metas das demais perspectivas ( $\mathrm{RECH}$, 2002).

Os indicadores da perspectivas financeiras podem diferir fortemente, dependendo do estágio atual de cada unidade de negócio, para tanto, pode-se classificar os estágios de ciclo de vida das unidades de negócio conforme é explicado na sequencia (MORONI, 2003; KAPLAN \& NORTON, 1996, 1997): 


\begin{tabular}{|c|c|c|c|}
\hline $\begin{array}{l}\text { Estratégia da Unidade } \\
\text { de Negócio. }\end{array}$ & $\begin{array}{c}\text { Crescimento do Faturamento e } \\
\text { Mix }\end{array}$ & Otimizações & $\begin{array}{l}\text { Utilização dos } \\
\text { Ativos }\end{array}$ \\
\hline Crescimento & $\begin{array}{l}\text {-Crescimento das vendas por } \\
\text { segmento. } \\
\text {-Percentagem das vendas por } \\
\text { novos clientes e segmentos. }\end{array}$ & -Receita / Funcionário. & $\begin{array}{l}\text {-Investimentos. } \\
\text {-Pesquisa \& } \\
\text { Desenvolvimento. } \\
\text { (Ambos em percentual } \\
\text { das Vendas) }\end{array}$ \\
\hline Manutenção & $\begin{array}{l}\text {-Vendas Cruzadas. } \\
\text {-Percentual de faturamento de } \\
\text { novas aplicações. } \\
\text {-Lucratividade por linha de } \\
\text { produto e por cliente. } \\
\text {-Participação de mercado por } \\
\text { cliente e conta. }\end{array}$ & $\begin{array}{l}\text {-Custo interno versus } \\
\text { concorrência. } \\
\text {-Taxa de redução de } \\
\text { custos. } \\
\text {-Gastos indiretos } \\
\text { (percentual das vendas). }\end{array}$ & $\begin{array}{l}\text {-Taxa de utilização dos } \\
\text { ativos. } \\
\text {-Índice de capital de giro. } \\
-R O C E \text { por categoria- } \\
\text { chave de ativo. }\end{array}$ \\
\hline Colheita & $\begin{array}{l}\text {-Lucratividade por cliente e } \\
\text { produto. } \\
\text {-Percentual de clientes não } \\
\text { lucrativos. }\end{array}$ & - Custo por unidade. & $\begin{array}{l}\text {-Retorno. } \\
\text {-Rendimento. }\end{array}$ \\
\hline
\end{tabular}

Tabela 4 - Medição dos temas financeiros estratégicos

Fonte: adaptado de Norton \& Kaplan (1996) e Norton \& Kaplan (1997)

- Crescimento: A unidade de negócios está no estágio inicial do ciclo de vida. Devem ser feitos pesados investimentos para desenvolver e aprimorar novos produtos e serviços, construir e expandir novas plantas industriais.

- Manutenção: Provavelmente a maior parte das empresas está nesta fase, em que ainda são necessários investimentos e re-investimentos, porém os mesmos necessitam ter taxas de retorno excelentes.

- Colheita: Fase na qual o negócio entra na maturidade do seu ciclo de vida e a empresa quer "colher" os investimentos feitos nas duas fases anteriores. Nesta fase a empresa deve-se limitar a projetos específicos com rápido retorno e o mínimo necessário para a manutenção dos equipamentos e sistema em uso.

\subsubsection{Perspectiva dos Clientes}

O segmento-alvo é definido através da perspectiva dos clientes e é destes clientes do desenvolvimento que a perspectiva financeira vai retirar seus rendimentos 
(MORONI, 2003; CLARKE \& TYLER, 2001). Devido ao exposto, Kaplan \& Norton (2000) descrevem que o foco de qualquer estratégia de negócios é a proposição de valor para o cliente que descreve a relação de produtos e serviços, o relacionamento com os clientes e a imagem corporativa que a empresa dispõe. Esta proposição de valor é crucial para diferenciar a empresa de seus concorrentes, no que se refere a atrair, manter e aprofundar a relação com os seus clientes.

A proposição de valor conforme exposto acima estabelece o contexto para que seja criado valor através dos ativos intangíveis. Por exemplo, se o valor para o cliente é qualidade e tempo de entrega, então as competências, sistemas e processos que produzem, garantem e entregam produtos e serviços de qualidade altamente valorizados pela organização. Em suma um alinhamento consistente das ações e capacidades com a proposição de valor do cliente é o foco e a execução da estratégia (NORTON \& KAPLAN, 2004).

Aprofundando e detalhando a questão, Kaplan \& Norton (1996) afirmam que é nesta perspectiva que os gerentes detalham os segmentos de mercado e os clientes com quem a unidade de negócio vai competir, e definem quais devem ser os indicadores de performance de negócio da unidade neste segmento objetivo. Os indicadores típicos podem ser: satisfação dos clientes, retenção dos clientes, aquisição de novos clientes, lucratividade por cliente e participação de mercado por segmentoalvo. 


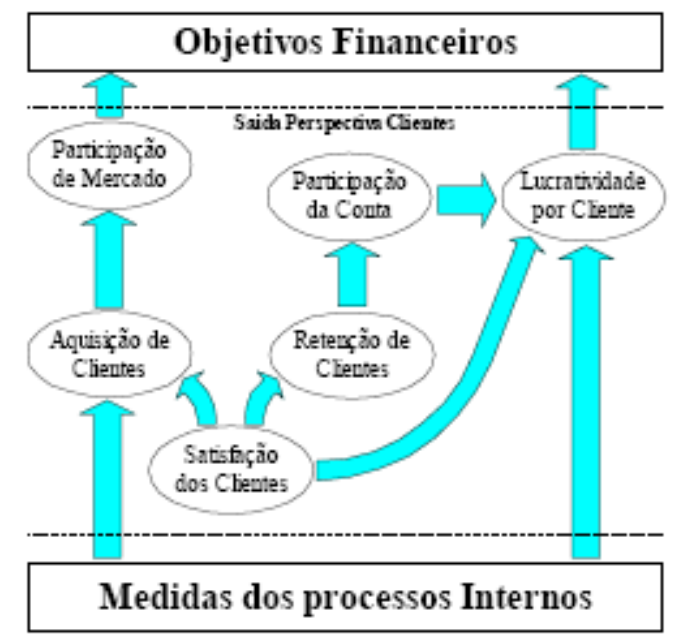

Figura 11 - Relacionamento dos indicadores de performance de clientes Fonte: adaptado de Kaplan \& Norton (1996)

\subsubsection{Perspectivas dos Processos Internos}

As perspectivas financeiras e de clientes descritas acima determinam os produtos desejados da estratégia, e ambas as perspectivas contêm muitos indicadores de ocorrência. Para a organização produzir estes resultados desejados, ela se vale da perspectiva dos processos internos. Nessa perspectiva, são identificados os poucos processos internos dos quais se espera terem grande impacto na estratégia. Por exemplo, uma unidade de negócios pode investir forte em pesquisa e desenvolvimento e alterar o processo de desenvolvimento de produtos, de modo a desenvolver produtos de alta-performance e inovadores para seus clientes (KAPLAN \& NORTON, 2004).

A perspectiva de processos internos do BSC demonstra duas diferenças fundamentais entre a abordagem tradicional e a abordagem do BSC. A abordagem tradicional tende a monitorar e otimizar os processos existentes, focalizando as medidas financeiras de performance e incorporando métricas de qualidade e tempo, enquanto a abordagem BSC busca identificar processos totalmente novos, nos quais a organização precisa de distinguir para atingir os objetivos dos clientes e financeiros. 
A abordagem BSC também se difere por incorporar o processo de inovação (Long-Wave de criação de valor) enquanto que a abordagem tradicional busca controlar e otimizar as operações existentes (Short-Wave de criação de valor) focando-se no processo de entrega dos produtos e serviços atuais para os clientes atuais (FIGUEIREDO, 2002; KAPLAN \& NORTON, 1997).

Existem literalmente centenas de processos acontecendo simultaneamente dentro de uma organização, cada um criando valor de alguma forma. Conforme Kaplan \& Norton (2004), "A arte da estratégia é identificar e distinguir quais são os poucos processos críticos que são mais importantes para proposição de valor dos clientes". Todos os processos devem ser bem gerenciados mas os poucos processos estratégicos devem receber especial atenção e foco, pois os mesmos criam a diferenciação estratégica. Estes processos estratégicos devem ser desenhados para todas as perspectivas. Cada estratégia deve identificar processos na Gestão das operações, Gerenciamento de Clientes e de Inovação de modo que o processo de criação de valor seja balanceado no curto e no longo prazo.

A partir da identificação dos processos internos devem-se definir os pontos críticos ao longo da cadeia de valor interna da empresa. A partir da identificação das necessidades atuais e futuras dos clientes devem-se desenvolver novas soluções que atendam estas demandas. O próximo passo é analisar e detectar como está o processo de entregas dos produtos e prestação de serviços aos clientes existentes, e por finalmente proceder à análise dos serviços de pós-venda (LIMA, 2003).

Apesar de cada empresa possuir seu conjunto de processos específicos conforme o mercado em que atua, de modo a gerar valor para seu cliente e produzir resultados financeiros, Lima (2003), Moroni (2003), Figueiredo (2002), Kaplan \& Norton $(1996,1997)$ propõem uma cadeia de valor genérica que serve como modelo para que as empresas possam adaptar ao construir a perspectiva dos processos internos. 
O modelo proposto é composto por três processos: Inovação, Operações e Serviço Pós-Venda, que descrevemos a seguir (LIMA, 2003; MORONI, 2003; FIGUEREIDO, 2002; RECH, 2002; KAPLAN \& NORTON, 1997):

- Processo de Inovação: parte do processo de criação de valor, no qual as empresas primeiras localizam e cultivam novos mercados, novos clientes e as necessidades emergentes e latentes dos atuais clientes. Após, partem para projetar e desenvolver novos produtos e serviços buscando alcançar novos mercados e clientes.

- Processo de Operações: parte do processo de valor que se inicia a partir do recebimento do pedido do cliente e termina na entrega do bem ou serviço ao solicitante. $O$ foco deste processo está na entrega eficaz, regular e pontual dos bens e serviços existentes aos atuais clientes.

- Processo de Serviços de Pós-Venda: parte do processo de valor que inclua garantia e conserto, correção de defeitos e devoluções, além do processamento dos pagamentos, faturamento e cobrança. Os parâmetros tempo, qualidade e custos são utilizados para avaliar o desempenho dos serviços de pós-vendas das empresas que buscam atender às expectativas dos seus clientes-alvo.

Kaplan \& Norton (2004) propõem nova classificação dos processos internos em: Gestão Operacional, Gestão de Clientes, Inovação e Regulatório e Social.

Olve, Roy \& Wetter (2001) ponderam que os indicadores referentes aos processos internos BSC são originários na sua maioria do TQM (Total Quality Management) ou projetos similares que envolvem tempo, qualidade da produção e rejeições. 


\subsubsection{Perspectiva de Aprendizagem e Crescimento}

Os indicadores de performance devem enfatizar a importância de investir no futuro, nas áreas de infra-estrutura (pessoas, sistemas e procedimentos) e não apenas nas áreas tradicionais de investimento (novos equipamentos e pesquisa / desenvolvimento de novos produtos), pois as áreas tradicionais não seriam autosuficientes. Esta idéia pode ser compreendida quando se entende que, por mais tecnologia que a empresa possua, sempre haverá necessidade de pessoas fazendo o processo funcionarem (LIMA, 2003; WILLIAM apud CAMPOS, 1996).

Conforme Kaplan \& Norton (2004) as empresas constroem seus mapas estratégicos da cabeça da empresa para baixo (TOP DOWN), começando pelos objetivos financeiros de longo prazo e então determinando o que irá gerar o crescimento de faturamento especificado para este objetivo, identificando os processos mais críticos para criação e entrega da proposição de valor e finalmente determinando o capital humano, de informação e organizacional requerido pelo processo que é o escopo da perspectiva de aprendizagem e crescimento.

A perspectiva de aprendizagem e crescimento identifica os ativos intangíveis mais importantes para a estratégia. O objetivo desta é identificar quais trabalhos (Capital humano), quais sistemas e que tipo de clima organizacional é necessário para suportar a criação de valor nos processos internos. Estes ativos intangíveis devem ser agrupados e alinhados com os processos internos (KAPLAN \& NORTON, 2004).

Conforme Frangos (2004) o mundo empresarial mudou nos últimos 20 anos, apenas $15 \%$ do valor de uma organização contemporânea podem ser valorados pelos ativos tangíveis. O capital humano se tornou o ativo dominante na moderna estratégia de negócios.

A quarta perspectiva do Balanced Scorecard, descreve os ativos intangíveis da organização e seu papel na estratégia. Os mesmos podem ser agrupados em três 
categorias (KAPLAN, 2004; KAPLAN \& NORTON, 2004): (I) Capital Humano - a disponibilidade de habilidades, talentos e capacidades necessárias para suportar a estratégia; (ii) Capital de Informação - a disponibilidade de um sistema de informação, redes e infra-estrutura necessária para suportar a estratégia; (iii) Capital da Organização - a habilidade da organização para mobilizar e sustentar o processo de mudança necessário à execução da estratégia.

Sveiby (2001), define os ativos intangíveis como capital intelectual e os dividem como Capital Externo, Capital Interno e Capital Humano estabelecendo que a tecnologia de informação funciona como uma plataforma de suporte e valorizando o conhecimento das pessoas da organização, como segue:

a) Capital Externo (estrutura externa da corporação): relação com os clientes e fornecedores, marcas, reputação e imagem. Dependem basicamente de como a organização resolve e oferece soluções para os problemas dos clientes.

b) Capital Interno (estrutura interna da corporação): são os conceitos, modelos, patentes, sistemas administrativos e informacionais criados pelas pessoas e utilizados na gestão das organizações.

c) Capital Humano (competências individuais): habilidades das pessoas em agir em determinadas situações. Está relacionado à educação, experiência, valores e habilidades sociais das pessoas.

Conforme Kaplan (2004) "Você não pode dar valor a ativos intangíveis, mas, certamente pode avaliar seu alinhamento com estratégias de alto valor da sua empresa". Este alinhamento entre os ativos intangíveis e as estratégias da empresa é chamado de "Prontidão Estratégica". O grau de "Prontidão Estratégica" está relacionado com a capacidade de Criar valor em ativos intangíveis diferindo fortemente da criação de valor no gerenciamento ativos tangíveis físicos e financeiros (KAPLAN \& NORTON, 2004). 
Se você tem uma força de trabalho muito bem treinada, como todas as aplicações e a infra-estrutura de TI (Tecnologia da Informação) de que necessita, você pode fornecer valor sobre a estratégia muito rápido. Você tem um alto grau de prontidão estratégica. Se você adota uma nova estratégia, os funcionários têm que ser retreinados e adquirir novas habilidades e vocês precisam de um novo conjunto de aplicações de TI, há um baixo grau de prontidão estratégica. Vai demorar muito para que ativos intangíveis sejam plenamente capazes de fornecer valor. É uma medida da rapidez com que pessoas, sistemas e cultura podem criar valor com uma estratégia.

a) Criação de Valor é indireta - ativos intangíveis como conhecimento e tecnologia raramente têm impacto direto em resultados financeiros como aumento do faturamento, redução dos custos e aumento dos lucros. A otimização nestes ativos intangíveis irá afetar os resultados financeiros indiretamente através da cadeia de relacionamento de causa-e-efeito. Por exemplo, podemos considerar que o treinamento em seis sigmas pode otimizar a qualidade do processo. Esta melhoria pode influenciar positivamente a satisfação do cliente, o que pode aumentar a lealdade do mesmo e esta, por sua vez, leva a um aumento das vendas e da margem em uma relação de longo prazo com o cliente.

b) Valor Contextual - o valor dos ativos intangíveis depende de seu alinhamento com a estratégia. Por exemplo, o treinamento em seis sigmas tem um valor maior para as organizações que buscam uma estratégia de redução do custo total do que em empresas que se focam em liderança no produto ou em estratégias de inovação.

c) Valor é Potencial - o custo de investimento em ativos intangíveis representa uma fraca estimativa de seu valor para a organização. Exemplificando, o treinamento em técnicas estatísticas dos seis sigmas tem um valor potencial, não um valor de mercado pois é necessário que os processos internos, como: engenharia, produção e logística transformem este valor potencial dos ativos intangíveis em valores tangíveis. Caso os processos internos não estejam alinhados com as proposições de 
valor dos clientes ou melhoria financeira, então o valor potencial das capacidades dos colaboradores, e os ativos intangíveis em geral não se realizarão.

d) Ativos devem ser Agrupados - ativos intangíveis raramente criam valor por eles mesmos. Ele não tem valores intrínsecos, que possam ser isolados do contexto da organização e da estratégia. $O$ valor dos ativos intangíveis advém da combinação efetiva dos mesmos com outros ativos quer sejam tangíveis ou intangíveis. Por exemplo, o treinamento em qualidade é amplificado quanto os colaboradores têm acesso a dados detalhados de sistemas de informação orientados nos processo.

Esta perspectiva é a fundação de qualquer mapa estratégico do Balanced Scorecard e apesar de os executivos reconhecerem a importância da mesma eles geralmente têm problemas na definição dos objetivos correspondentes (KAPLAN \& NORTON, 2000).

\subsubsection{Relações de Causa e Efeito}

Conforme Kaplan \& Norton (1997) podemos definir estratégia como um conjunto de hipótese de causa e efeito, sendo que esta relação pode ser expressa por uma seqüência de afirmativas "se-então". Um BSC bem construído deve contar a história da estratégia da unidade de negócios e o sistema de medição deve ser capaz de estabelecer o relacionamento (hipóteses) entre os objetivos (e medidas) das várias perspectivas permitindo que elas sejam gerenciadas e validadas.

A cadeia de causa e efeito deve atravessar todas as quatro perspectivas do

BSC. Através da descrição dos investimentos na perspectiva aprendizagem e crescimento, os gestores podem começar a ver os efeitos de segundas e terceiras ordem que este investimento causará na qualidade, clientes e faturamento, conforme figura (FRANGOS, 2004). 


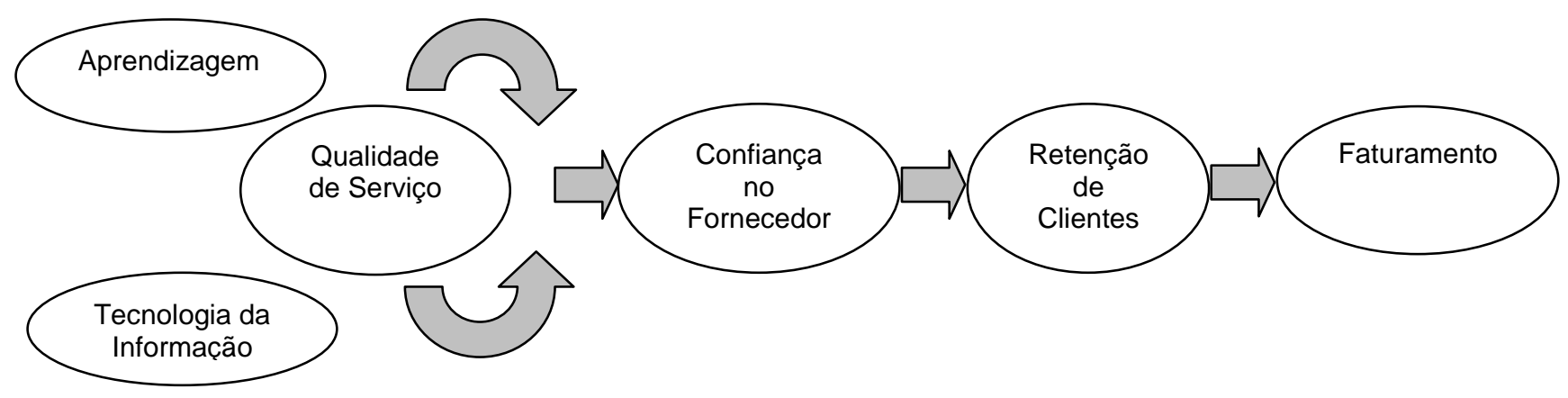

Figura 12 - Relacionamento dos indicadores de performance de clientes Fonte: adaptado de Kaplan \& Norton (1996)

Embora grande parte dos gestores entenda intuitivamente a cadeia de causa e efeito, os mesmos encontram dificuldades em defini-las e mapeá-las. A causa-raiz é que a maior parte das organizações não dispõe de um modo claro para comunicar a estratégia. Conforme um estudo apresentado pela revista Fortune, mais de 95\% da força de trabalho não entende a estratégia da organização e $90 \%$ das organizações falham na hora de executar suas estratégias. Este problema existe porque estas organizações não têm ferramentas de planejamento estratégico que possibilitem às mesmas definir suas estratégias (FRANGOS, 2004; GOODERHAN, 1998).

Considerando que o Balanced Scorecard traduz as estratégias para todos os níveis da organização, o mesmo pressupõe uma relação causa e efeito entre os indicadores das diversas perspectivas. Por exemplo, um indicador financeiro de retorno sobre os investimentos, pode estar associado à expansão e à retenção de clientes. Sendo assim, um indicador adequado na perspectiva de clientes pode ser a lealdade ou índice de retenção dos clientes. Esta relação de causa e efeito atravessa todas as perspectivas relacionando desde a satisfação dos funcionários, passando pela lealdade dos clientes e chegando ao seu conseqüente retorno financeiro (KAPLAN \& NORTON, 1996; HESKETT 1994).

Segundo Olve, Roy \& Wetter et al (2001) "O grande desafio é encontrar relações de causa e efeito claras e criar um equilíbrio entre os diferentes indicadores nas perspectivas relacionadas", como também, "é importante incluir a discussão sobre se o 
equilíbrio pode ser alcançado entre as diferentes perspectivas de modo tal que as melhorias de curto prazo não conflitem com as metas de longo prazo". E, ainda, conforme os autores, "Um dos mais importantes aspectos do diagrama de causa e efeito é o seu papel de aprendizado da estratégia, e seu papel na criação de uma organização de aprendizado".

O índice de relacionamento entre os diversos indicadores pode ser obtido através da utilização de análise de correlação (Kaplan apud Sim, Koh, 2001). Utilizando-se esta análise pode-se estabelecer o nível de intensidade das relações de causa e efeito bem como avaliar se as mesmas são positivas ou negativas. Através deste conhecimento podemos aprimorar os gerenciamentos dos processos associados.

\subsubsection{Mapas Estratégicos}

A estratégia descreve como uma empresa pretende criar valor sustentável para seus acionistas, não se tratando de um processo de gestão que se mantém por si próprio. A estratégia insere-se em um contexto maior, sendo parte integrante de um processo lógico e contínuo que irá mover a empresa a partir da declaração da missão de alto nível até a execução efetiva do trabalho pelos colaboradores da empresa (KAPLAN \& NORTON, 2004).

Mas não basta só definir a estratégia, é necessário planejar a sua implementação pois conforme Atkinson (2004) "Falhar em planejamento é planejar para falhar". São necessários três elementos para fazer a estratégia funcionar, foco, energia e alinhamento. Foco é crítico porque indica a direção e progresso, ou seja, sem um objetivo a empresa se tornará um caos, haja vista que seus colaboradores não saberão em que direção seguir. Energia relaciona-se ao fato de que a empresa precisa motivar seus recursos a atingir seus objetivos. Alinhamento, por fim, é garantir que todos os recursos estejam direcionados para a mesma direção (ATKINSON, 2004). 
Conforme Rummler \& Brach et al (1994), "Uma estratégia sólida é apenas metade da batalha. Em nossa experiência, a maioria das estratégias que nunca chegaram a ter sucesso não fracassou por falta de uma visão viável e clara; elas estão empoeirando por que foram mal implementadas".

Mapas estratégicos apresentam para os colaboradores uma linha clara de como os seus trabalhos estão conectados com os objetivos gerais da organização propiciando à mesma trabalhar de forma colaborativa e coordenada em direção aos objetivos da empresa. Os mapas constituem uma representação visual de como os objetivos críticos e os relacionamentos cruciais entre eles que movem a performance da organização (KAPLAN \& NORTON, 2000).

Bush e Barrows (2004) ponderam que Kaplan \& Norton propuseram que o BSC fornece à empresa uma poderosa ferramenta para unidades de negócios individuais descreverem e implementarem suas estratégias. Porém, quando a mesma consiste de diferentes unidades de negócio, em uma organização focada na estratégia, é necessário mais do que cada empresa administrando seu negócio a partir do seu Mapa estratégico individual. Para a máxima efetividade as estratégias e os mapas estratégicos de cada unidade devem estar alinhados e ligados entre si. Estas ligações alinham a estratégia da organização e desse modo, a empresa irá criar sinergias de valor pela integração das atividades que de outro modo estariam segregados por unidade. 


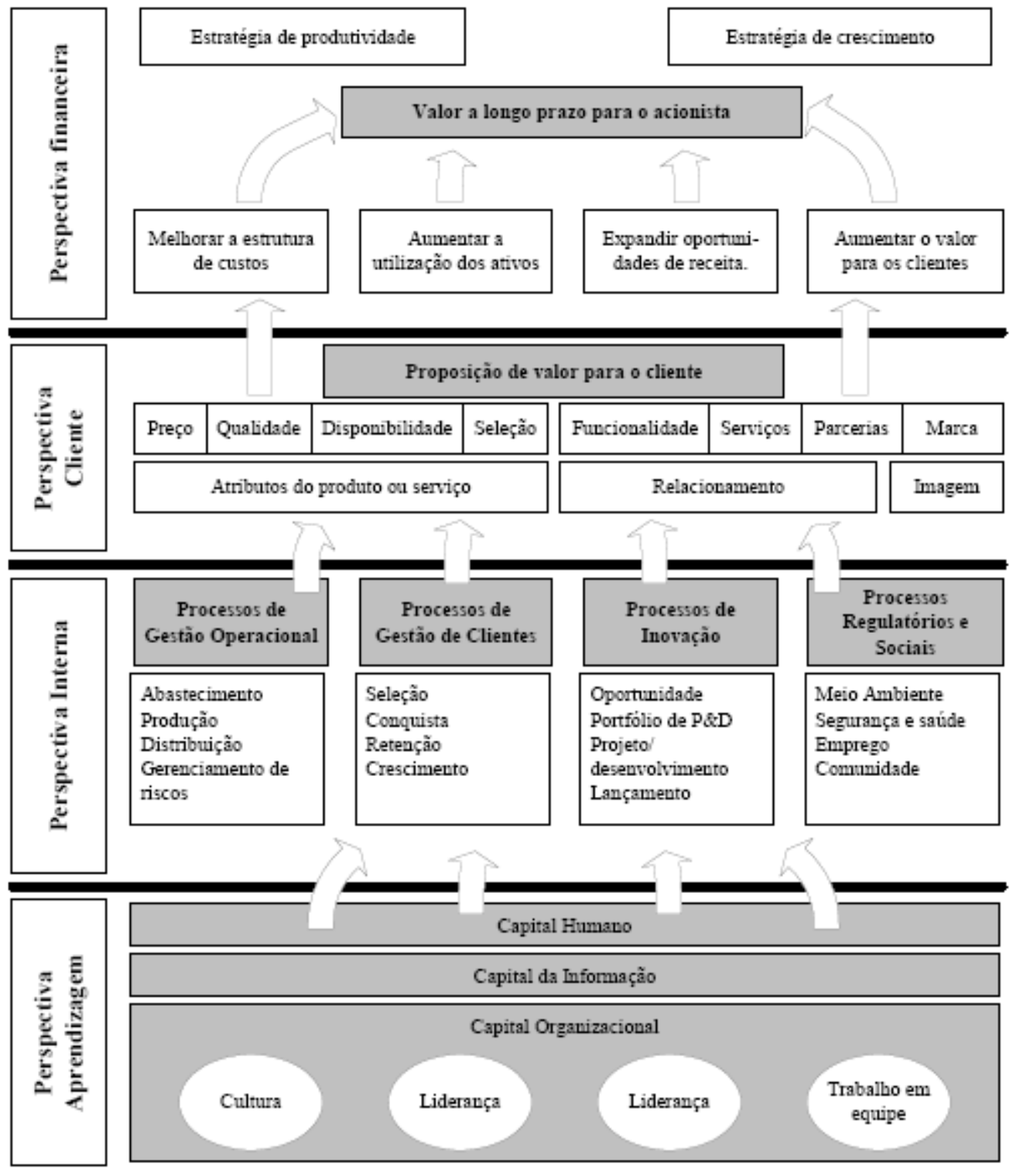

Figura 13 - Mapa Estratégico

Fonte: adaptado de Norton e Kaplan (2004)

O mapa estratégico baseia-se em alguns princípios:

- A estratégia equilibra-se em forças contraditórias - Haja vista que o investimento em ativos intangíveis no sentido de proporcionar o aumento de receitas no longo prazo conflita com o corte nos custos visando melhorar o desempenho financeiro no curto prazo. 
- A estratégia baseia-se na proposta de um valor diferenciado para os diferentes segmentos de clientes - considerando que a satisfação dos clientes é a fonte da criação de valor sustentável no presente e futuro, deve-se estabelecer uma clara definição dos segmentos de clientes alvo e a respectiva proposta de valor para agradá-los. Pode-se dividir em quatro diferentes proposições de valor.

- Baixo custo total.

- Liderança no produto.

- Soluções completas para os clientes.

- Aprisionamento.

- Cria-se valor por meio dos processos internos - os processos internos mostram como a organização implementará a estratégia e podem ser classificados em quatro diferentes grupamentos:

- Gestão Operacional - produção e entrega de produtos e serviços aos clientes.

- Gestão de Clientes - estabelecimento e alavancagem dos relacionamentos com os clientes.

- Inovação - desenvolvimento de novos produtos, serviços, processos e relacionamentos.

- Regulatório e Social - processo interno de obter a conformidade com as expectativas regulatórias e sociais e do desenvolvimento de comunidades mais fortes.

- A estratégia compõe-se de temas complementares e simultâneos - os diferentes grupamentos apresentados acima auferem resultados em tempos diferentes. A otimização dos processos operacionais obtém resultados em curto prazo, em 
contrapartida os benefícios decorrentes do fortalecimento com clientes irão começar a aparecer de seis a doze meses após a execução das melhorias nos processos de gestão de clientes. Os processos de Inovação possuem ciclo de maturação ainda maior gerando resultados geralmente no longo prazo. Por fim os processos internos referentes ao regulatório e social podem gerar resultado em um futuro maior ainda à medida que as empresas evitam litígios. Assim sendo, na medida em que a organização adota pelo menos um tema estratégico de cada destes grupamentos, ela obtém benefícios que gerarão resultados sustentáveis ao longo do tempo.

- O alinhamento estratégico determina o valor dos ativos intangíveis - os ativos intangíveis somente geram valor se estiverem fortemente alinhados com as estratégias da empresa, e conforme exposto anteriormente (vide perspectiva aprendizagem e crescimento) não geram valor se considerados de forma independente. De modo a obter-se o alinhamento dos mesmos com a estratégia Kaplan \& Norton (2004) identificaram três abordagens básicas:

- Funções estratégicas, que devem alinhar o capital humano com os temas estratégicos.

- Portfólio estratégico de TI, que deve alinhar o capital da informação com os temas estratégicos.

- Agenda de mudanças organizacionais, que deve alinhar e integrar o capital organizacional buscando o aprendizado e a melhoria contínua dos temas estratégicos.

- Assim a partir do alinhamento dos componentes da perspectiva de Aprendizagem e Crescimento com a estratégia obtém-se um alto grau de prontidão estratégica. Consegue-se um grande nível de prontidão estratégica quando: 
- As capacidades do capital humano nas funções estratégicas estão fortemente alinhadas com os temas estratégicos.

- O capital da informação dispõe e fornece a infra-estrutura vital e aplicações estratégicas de TI complementando o capital humano de modo a obter um alto desempenho dos temas estratégicos.

- A mudança do clima organizacional necessária para a execução da estratégia é reforçada através da cultura, liderança, alinhamento e trabalho em equipe (KAPLAN \& NORTON, 2004).

\subsubsection{Número de Medidas para cada Scorecard e Perspectiva}

Segundo Olve, Roy \& Wetter (2001) o número de medidas pode variar de acordo com o nível do "scorecard ou perspectivas específicas". Nos níveis da corporação e da unidade de negócios são habitualmente utilizadas de 15 a 20 medidas de desempenho, enquanto que no nível divisional / funcional somente de 10 a 15 são consideradas verdadeiramente críticas e finalmente no nível individual e de grupo poucas medidas tendem a ser necessárias, geralmente de 5 a 10.

O número de medidas de desempenho críticas diminui à medida que descemos na organização em função da relevância destas medidas e da possibilidade de influência nas mesmas pelas pessoas ou unidades, pois se deve evitar medir pessoas ou departamentos sob variáveis que os mesmos não têm como influenciar.

Outro ponto que reduz a quantidade de medidas é o fato de se tentar combinar várias medidas em uma só na performance da unidade.

\subsubsection{Pontos Importantes para o Sucesso do Balanced Scorecard}

Conforme Shih-Jay \& Mckay (2002) para o sucesso da BSC no longo prazo alguns pontos devem ser levados em conta: 
- Feedback imediato é essencial para a efetividade do Balanced Scorecard.

- O BSC funciona melhor quando os colaboradores são envolvidos na definição dos parâmetros iniciais.

- O BSC é essencialmente mais importante em momentos de mudança organizacional, pois o mesmo é projetado para garantir que "feedbacks" críticos sejam mantidos e monitorados. Durante estas mudanças organizacionais a tendência é que sejam definidas soluções com ótimos locais em detrimento das conseqüências de longo prazo.

- Por fim o número e tipos de parâmetros selecionados pelo BSC precisam ser bem definidos com antecedência, visto que o mesmo deve conter um número gerenciável de parâmetros evitando o consumo excessivo de tempo para operar com o mesmo.

Conforme Olve, Roy \& Wetter (2001) após a definição da estratégia, devem ser avaliados quais os requisitos necessários para obter sucesso na visão delineada e quais os fatores que surtiram maior efeito nos resultados almejados, ou seja, a própria empresa deve decidir quais os fatores críticos para o sucesso e colocá-los em ordem hierárquica. A construção do primeiro scorecard funciona melhor numa unidade estratégica de negócios, de preferência uma que tenha atividades de uma cadeia de valores completa: inovação, operações, marketing, vendas e serviços. Esse tipo de unidade tem seus próprios produtos e clientes, operações de marketing e canais de distribuição e instalações de produção (KAPLAN \& NORTON, 2000).

\subsection{Comparativo entre os Modelos de Avaliação de Desempenho Estudados}

Conforme Muller (2003) a partir da tabela 5 que apresenta um resumo dos principais elementos, contribuições e desvantagens dos modelos de avaliação de desempenho são possíveis conceber um modelo mais ajustado possível, o qual poderá 
ser a combinação conveniente de vários autores de modo a neutralizar os pontos fracos e utilizar os pontos fortes.

\begin{tabular}{|c|c|c|c|}
\hline \multirow{2}{*}{$\begin{array}{c}\begin{array}{c}\text { Características/ } \\
\text { Critério de } \\
\text { Análise }\end{array} \\
\text { Descrição } \\
\end{array}$} & \multicolumn{3}{|c|}{ Diferenciais do Modelo } \\
\hline & Principais elementos & Principal (is) contribuição (ôes) & Eventuais desvantagens \\
\hline $\mathrm{BSC}$ & $\begin{array}{l}\text { Perspectivas; } \\
\text { Objetivo,Indicador,Meta } \\
\text { e Iniciativa. } \\
\text { Mapa estratégico. } \\
\text { Indicador de resultado e } \\
\text { vetor de desempenho. } \\
\end{array}$ & $\begin{array}{l}\text { Estruturação; } \\
\text { Equilibrio (balanceamento); } \\
\text { Mapa estratégico - relações de } \\
\text { causa-e-efeito. }\end{array}$ & Complexidade. \\
\hline $\mathrm{CI}$ & $\begin{array}{l}\text { Foco= Perspectivas; } \\
\text { Tipos de capital } \\
\text { Intelectual. } \\
\text { BUSINESS NAVIGATOR }\end{array}$ & $\begin{array}{l}\text { Preocupação com o futuro; } \\
\text { Ênfase na pessoa; } \\
\text { Índice de inovação tecnológica } \\
\text { bem atuais. }\end{array}$ & $\begin{array}{l}\text { Dimensionamento - Número } \\
\text { elevado de indicadores. }\end{array}$ \\
\hline Quantum & $\begin{array}{l}\text { Matriz Quantum; } \\
\text { Geradores; } \\
\text { Facilitadores; } \\
\text { O processo em si; } \\
\text { Melhoria continua. }\end{array}$ & $\begin{array}{l}\text { Procedimento passo a passo: } \\
\text { Visão explicita de processos } \\
\text { horizontais. }\end{array}$ & $\begin{array}{l}\text { Resume o desempenho em } \\
\text { somente três dimensões. }\end{array}$ \\
\hline $\begin{array}{l}\text { Rummler \& } \\
\text { Brache }\end{array}$ & Niveis. & $\begin{array}{l}\text { Procedimento passo a passo. } \\
\text { Visão explicita de processos } \\
\text { horizontais. } \\
\text { Diferenciação de indicadores por } \\
\text { cargo ao nivel das pessoas. }\end{array}$ & \\
\hline Sink \& Tuttle & $\begin{array}{l}7 \text { dimensões do } \\
\text { desempenho; } \\
\text { Estrutura de } \\
\text { relcionamento. }\end{array}$ & $\begin{array}{l}\text { Definição clara de alguns } \\
\text { conceitos; } \\
\text { Relacionamento entre as } \\
\text { dimensões competitivas; } \\
\text { Incorporações de dimensões } \\
\text { superiores à financeira. }\end{array}$ & $\begin{array}{l}\text { Ao usar as } 7 \text { dimensões em } \\
\text { vários processos, pode levar } \\
\text { ao excesso de indicadores. }\end{array}$ \\
\hline
\end{tabular}

Tabela 5 - Resumo das principais características dos modelos de avaliação de desempenho Fonte : Muller et al 2003

Moreira (2002) comparou os modelos de Sink \& Tuttle, Quantum, Rummler \& Brache e o BSC sob quatro perspectivas diferentes: (I) formulação da estratégia; (ii) desdobramento do objetivo estratégico; (iii) entendimento e divulgação do objetivo estratégico; e (iv) acompanhamento da implementação da estratégia escolhida.

Através de um sistema de setas a partir da observação de cada modelo, posicionou cada um com as seguintes considerações; seta para cima significa 
predominância de aspectos positivos na perspectiva; seta para baixo significa predominância de aspectos negativos e finalmente seta na horizontal, quando não houve predominância ou não foi possível identificar as características na perspectiva em questão. Isso pode ser melhor compreendido através da Tabela 6. Os aspectos considerados em cada perspectivas são descritos a seguir:

a) Conforme Mintzberg et al, apud Moreira (2002) as escolas de pensamento estratégico, na linha mais prescritivista (Design, Planejamento e Posicionamento), podem inibir as realimentações durante a implementação ao separarem as etapas de formulação e implementação da estratégia. Por outro lado, as escolas subjetivas (Aprendizado, Ambiental, dentre outras) são mais flexíveis aos pequenos desvios na implementação. Esta implementação é fruto do aprendizado estratégico.

b) Avalia-se se no modelo pesquisado existe uma sistemática estruturada, menos empírica, que, a partir do desdobramento do objetivo chegue até as ações em nível operacional.

c) Verifica-se se o modelo dispõe de um processo de comunicação/divulgação dos objetivos estratégicos e seus respectivos desdobramentos de modo a favorecer o entendimento e o comprometimento de toda a organização.

d) Verifica-se no modelo quais são as referências de acompanhamento adotadas de modo a garantir a realização da estratégia almejada e a sua possível eficácia quanto a feedback e à geração de ações de correções de desvio. 


\begin{tabular}{|c|c|c|c|c|}
\hline Modelo de: & $\begin{array}{c}\text { Formulação da } \\
\text { Estratégia }\end{array}$ & $\begin{array}{c}\text { Desdobramento do Obj. } \\
\text { Estratégico }\end{array}$ & $\begin{array}{c}\text { Entendimento e } \\
\text { Divulgação }\end{array}$ & $\begin{array}{l}\text { Acompanhamento da } \\
\text { Implementação }\end{array}$ \\
\hline $\begin{array}{l}\text { Sink e } \\
\text { Tuttle }\end{array}$ & $\begin{array}{l}\text { Escolas do } \\
\text { Planejamento, } \\
\text { Posicionamento e } \\
\text { Aprendizado }\end{array}$ & $\begin{array}{l}\text { Técnica de Grupo } \\
\text { Nominal } \\
\text { (brainstorming } \\
\text { estruturado) }\end{array}$ & $\begin{array}{l}\text { Implicito no processo } \\
\text { participativo de } \\
\text { desdobramento }\end{array} \downarrow$ & $\begin{array}{l}\text { Com auxilio de } \\
\text { indicadores medidos } \\
\text { em sete critérios de } \\
\text { performance }\end{array}$ \\
\hline Hronec & Escola de Design & $\begin{array}{l}\text { Matriz Quantum de } \\
\text { base genérica }\end{array}$ & $\begin{array}{l}\text { Treinamento e } \\
\text { sistema de } \\
\text { recompensas para } \\
\text { conscientização } \\
\end{array}$ & $\begin{array}{l}\text { Indicadores de } \\
\text { processo nas } \\
\text { dimensões qualidade, } \\
\text { tempo e custo }\end{array}$ \\
\hline $\begin{array}{l}\text { Rummler \& } \\
\text { Brache }\end{array}$ & $\begin{array}{l}\text { Escola de Design, } \\
\text { Posicionamento e } \\
\text { Ambiental }\end{array}$ & $\begin{array}{l}\text { Mapas de } \\
\text { relacionamento e de } \\
\text { processo do estado } \\
\text { atual e ideal }\end{array}$ & $\begin{array}{l}\text { Questionários com } \\
\text { auxilio de uma matriz } \\
\text { de base genérica }\end{array}$ & $\begin{array}{l}\text { Indicadores nos três } \\
\text { niveis de } \\
\text { desempenho, com } \\
\text { ênfase para processos }\end{array}$ \\
\hline $\begin{array}{l}\text { Kaplan \& } \\
\text { Norton }\end{array}$ & $\begin{array}{l}\text { Escolas do } \\
\text { Posicionamento e } \\
\text { Aprendizado }\end{array}$ & Mapas Estratégicos & $\begin{array}{l}\text { Utiliza a própria } \\
\text { arquitetura do modelo }\end{array}$ & $\begin{array}{l}\text { Indicadores nas } \\
\text { perspectivas } \\
\text { financeira, cliente, } \\
\text { processos e } \\
\text { aprendizado. }\end{array}$ \\
\hline Legenda: & \multicolumn{4}{|c|}{$\begin{array}{l}\uparrow \text { Pode ser considerado um ponto forte do modelo } \\
\downarrow \text { Pode ser considerado um ponto fraco do modelo } \\
\leftrightarrow \text { É indiferente (nem forte e nem fraco) }\end{array}$} \\
\hline
\end{tabular}

Tabela 6 - Comparativo proposto por Moreira

Fonte: adaptado de Moreira (2002)

Dos modelos analisados Moreira (2002) considera que o BSC se mostrou uma ferramenta robusta e que facilita a estruturação da problemática da gestão de desempenho nas empresas.

A partir da observação dos modelos analisados, então, pode-se visualizar um ponto de melhoria que é relativo ao desdobramento dos objetivos estratégicos (MOREIRA, 2002).

Rech (2002) traçou um comparativo entre os modelos Quantum, Capital Intelectual e Balanced Scorecard utilizando-se de alguns critérios comuns entre eles, com foco no desempenho organizacional conforme Tabela 7 , onde $\mathrm{R}+$ representa uma relação mais intensa com o modelo e $\mathrm{R}$ - uma relação menos intensa com o modelo. 


\begin{tabular}{l|c|c|c}
\hline & Quantum & Capital Intelectual & BSC \\
\hline Relativos à estratégia & $\mathrm{R}+$ & $\mathrm{R}+$ & $\mathrm{R}^{+}$ \\
\hline $\begin{array}{l}\text { Quanto ao estabelecimento } \\
\text { de metas }\end{array}$ & $\mathrm{R}+$ & $\mathrm{R}-$ & $\mathrm{R}^{+}$ \\
\hline Quanto ao foco dos clientes & $\mathrm{R}+$ & $\mathrm{R}^{+}$ & $\mathrm{R}^{+}$ \\
\hline $\begin{array}{l}\text { Inserção de medida nos } \\
\text { processos }\end{array}$ & $\mathrm{R}^{+}$ & $\mathrm{R}-$ & $\mathrm{R}^{+}$ \\
\hline $\begin{array}{l}\text { Quanto aos aspectos da } \\
\text { qualidade }\end{array}$ & $\mathrm{R}+$ & $\mathrm{R}-$ & $\mathrm{R}^{+}$ \\
\hline $\begin{array}{l}\text { Quanto à praticidade de } \\
\text { gestão }\end{array}$ & $\mathrm{R}-$ & $\mathrm{R}-$ & $\mathrm{R}^{+}$ \\
\hline $\begin{array}{l}\text { Sobre o aprendizado e } \\
\text { crescimento }\end{array}$ & $\mathrm{R}-$ & $\mathrm{R}+$ & $\mathrm{R}^{+}$ \\
\hline $\begin{array}{l}\text { Referentes a treinamento } \\
\text { Clareza das relações causa } \\
\text { e efeito }\end{array}$ & $\mathrm{R}-$ & $\mathrm{R}+$ & $\mathrm{R}^{+}$ \\
\hline
\end{tabular}

Tabela 7 - Comparativo entre os modelos segundo Rech

Fonte: adaptado de Rech (2002)

De acordo com Redi (2003) o modelo BSC opera com uma visão de cadeia de valor dos processos e os desdobramentos dos objetivos são realizados através de um foco multifuncional enquanto que no caso de GPD (gerenciamento por diretrizes) os desdobramentos são realizados através de uma visão funcional.

Lee e Ko (2000) consideram que o BSC tem dois pontos fracos:

(i) O primeiro ponto fraco é que o BSC é mais um método de efetivamente medir estratégia do que decidir estratégia;

(ii) E o segundo ponto fraco é que o BSC não detalha o como, ou seja, o desdobramento claro dos objetivos estratégicos proporcionando que cada nível hierárquico identifique exatamente qual a sua participação na estratégia.

Redi (2003) também argumenta que existem muitos pontos de complementaridade entre o GPD e o BSC e que estes pontos podem ser utilizados para alavancar a implementação da estratégia dentro da organização. 


\subsection{Considerações quanto aos Modelos de Avaliação de Desempenho Estudados}

Conforme apresentado por Muller (2003) uma das grandes contribuições do modelo BSC é sua capacidade de estruturação e a relação de causa e efeito. Isto é reforçado por Bontis, Dragonetti, Jacobsen \& Roos (1999) quando os mesmos salientam a lógica do BSC.

A partir da avaliação de Moreira (2002) descarta-se o modelo Sink \& Tuttle devido sua fraca capacidade de desdobramento dos objetivos estratégicos, bem como à baixa capacidade de entendimento e divulgação do mesmo. A partir também da avaliação de Moreira (2002) descarta-se o modelo Quantum devido aos seus pontos fracos serem a formulação da estratégia e o desdobramento dos objetivos estratégicos serem pontos fracos neste modelo. Finalmente, o modelo Rummler \& Brache foi desconsiderado pelos mesmos motivos observados no modelo Quantum.

A partir da observação de Rech (2002) o modelo de desempenho de Capital Intelectual apresenta problemas de estabelecimento de metas, inserção de medidas de processos, praticidade de gestão e clareza das relações de causa e efeito. Sendo assim, o modelo que apresentou a melhor avaliação a partir da bibliografia foi o Balanced Scorecard (BSC).

As observações complementares que podem ser citadas ao final deste capítulo são:

- Conforme Muller (2003) é possível obter um modelo mais ajustado a partir da combinação de vários autores neutralizando os pontos fracos de um modelo único.

- Conforme Moreira (2002) e Lee \& Ko (2000) um ponto fraco do modelo BSC é o desdobramento das diretrizes. 
- Segundo Akao (1997) o desdobramento das diretrizes através do processo catchball é um dos grandes diferenciais do Hoshin Kanri.

- De acordo com Redi (2003) os modelos GPD (gerenciamento por diretrizes) e BSC (Balanced Scorecard) têm pontos de complementaridade.

- Conforme Redi (2003) no Hoshin Kanri o desdobramento das diretrizes é feito a partir de uma estrutura funcional diferentemente do BSC que opera a partir da cadeia de valor em um foco multifuncional.

- Optou-se, então, por utilizar o modelo BSC com o desdobramento das diretrizes do Hoshin Kanri.

Assim, o modelo final para a realização deste trabalho de dissertação foi à associação dos objetivos estratégicos ao modelo Hoshin Kanri para o desdobramento dos mesmos ao longo da estrutura departamental, e, a partir desse desdobramento, a utilização do modelo BSC para a construção dos mapas estratégicos e indicadores de desempenho. 


\section{CAPÍTULO 3 - PROPOSTA DE MODELO PARA IMPLANTAÇÃO DE UM SISTEMA DE INDICADORES DE DESEMPENHO}

Este capítulo aborda a proposta de um modelo de implantação do sistema de indicadores de desempenho com uma estrutura que contempla elementos do Hoshin Kanri e do BSC.

A construção de um scorecard piloto funciona melhor numa unidade estratégica de negócios, de preferência uma que tenha atividades de uma cadeia de valores completa: inovação, operações, marketing, vendas e serviços. Esse tipo de unidade tem seus próprios produtos e clientes, operações de marketing e canais de distribuição e instalações de produção.

A questão relevante é se a unidade organizacional possui uma estratégia para realizar sua missão. Em caso afirmativo, a unidade é uma candidata válida ao Balanced Scorecard.

Definida e selecionada a unidade, o coordenador da implantação deve analisar o relacionamento da unidade com outras unidades, além da estrutura divisional e corporativa.

Este coordenador realizará entrevistas com os principais executivos nos níveis divisionais e corporativos para conhecer:

- Os objetivos financeiros estabelecidos para a unidade (crescimento, lucratividade, fluxo de caixa, volumes de extração).

- Os temas coorporativos primordiais (meio ambiente, segurança, políticas em relação aos funcionários, relacionamento com a comunidade, qualidade, competitividade de preços, inovação). 
- Relações com outras unidades (clientes comuns, competências essenciais, oportunidades para abordagens interadas a clientes, relacionamento entre fornecedores e clientes internos).

Em princípio não existe um modelo formalmente estabelecido ou único. Contudo, propõe-se na seqüência atividades que podem auxiliar no processo de implantação do modelo.

\subsection{Criação das Declarações da Missão e da Visão}

O primeiro passo, a ser realizado é definir qual a missão e a visão da organização, já que as declarações da missão e da visão são os fatores que orientam o planejamento estratégico.

A declaração da missão aponta as crenças essenciais, e identifica os mercadosalvo. Uma declaração de missão deve ser inspiradora, deve fornecer energia e motivação para a empresa. Ela representa para a empresa a razão de sua existência (RIBEIRO, 2002).

O primeiro passo, para a declaração da missão consiste em identificar claramente o propósito da empresa tomando-se o devido cuidado para que este propósito tenha o seu grau de abstração devidamente delimitado. Por exemplo, uma indústria automobilística que tenha como missão "construir carros" pode estar limitando sua área de atuação. Se esta mesma empresa assume como missão "mover pessoas" ela estará abrangendo novas áreas de transporte, não se limitando somente a carros abastecidos por gasolina, com pneus de borracha, que se movam no solo (RIBEIRO, 2002).

Em geral, a missão é uma declaração mais longa e além de esclarecer o negócio de uma empresa, também indica para quem a empresa se dirige e como ela pretende 
avançar em seus negócios. Isso significa que a empresa deve ter claramente definido quem é seu cliente.

Segundo Ribeiro (2002), declaração da visão é algo bem mais peculiar a cada tipo de organização, o que torna inaplicável a formulação de uma receita para elaborála. Contudo, algumas orientações são bastante úteis ao processo de concepção de uma visão. Sendo assim, a declaração de visão deve:

- Retratar um estado futuro desejado;

- Ser de longo prazo;

- Ter uma descrição clara;

- Estar alinhada com os valores centrais da empresa;

- Ser inspiradora e impulsionadora;

- Prover focalização e alinhamento;

- Prescindir de maiores explicações;

- Confrontar padrões atuais.

\subsection{Definição das Perspectivas e Identificação dos Objetivos Estratégicos para as Mesmas}

A estrutura central do BSC normalmente contém quatro perspectivas que podem ser aplicadas independentemente do tipo de empresa com a qual se está trabalhando: perspectiva financeira, perspectiva de mercado e clientes, perspectiva de processos internos de negócio (perspectiva interna) e perspectiva de aprendizado e crescimento (aprendizado e crescimento). Ainda pode ser necessário desdobrar-se em mais algumas perspectivas. Isto ocorre quando outro assunto (ex.: regulamentação, consciência ambiental, etc.) apresenta grande importância para a estratégia. Em seguida, os objetivos estratégicos são determinados dentro de cada perspectiva.

As seguintes reflexões com relação às quatro perspectivas do BSC podem auxiliar a equipe no momento de elaborar os objetivos da empresa: 
- Perspectiva Financeira: "Para termos sucesso financeiro, como devemos ser vistos por nossos acionistas?"

- Perspectiva dos clientes: "Para atingir nossa visão, como devemos ser vistos por nossos clientes?"

- Perspectiva interna: "Para satisfazer nossos clientes e acionistas, em quais processos de negócios devemos nos sobressair?"

- Perspectivas do aprendizado e crescimento: "Para atingir nossa visão, como a organização deve aprender e inovar?"

Teoricamente falando, os objetivos poderiam ser definidos independentemente da análise da situação atual. Na prática, é uma boa idéia estabelecer os objetivos de maior exeqüibilidade. Ainda, os objetivos devem ser coerentes entre si e devem estar de acordo com a missão da empresa. Eles devem auxiliar na tentativa de se alcançar a visão.

A figura 14 aborda como os objetivos se inserem dentro da estrutura do Balanced Scorecard. 


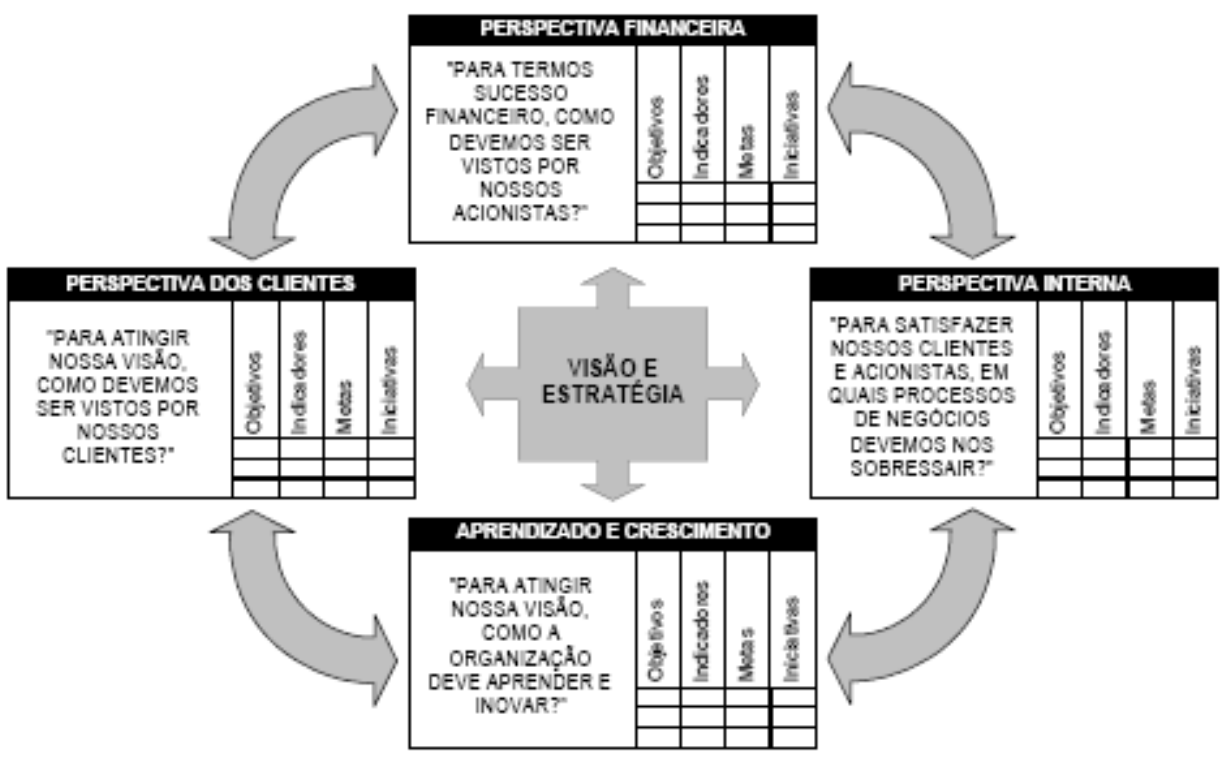

Figura 14 - Estrutura do BSC

Fonte: adaptado de Kaplan \& Norton (1992)

\subsection{Desdobramento dos Objetivos Estratégicos da Alta Administração}

Para traduzir o mapa estratégico do BSC da alta administração dentro de uma empresa para os níveis inferiores da organização, utilizam-se elementos da metodologia do "Hoshin Kanri" conforme referenciado na revisão bibliográfica. A aplicação da metodologia de desdobramento das diretrizes do modelo de gestão de desempenho "Hoshin Kanri" permite desdobrar as diretrizes desde o mapa estratégico do presidente até os níveis intermediários da organização.

Uma diretriz é composta pela meta (Objetivo Estratégico no modelo BSC) e medidas que são os planos de ação para atingir a meta. $O$ método adotado consiste em desdobrar apenas a Meta (Objetivo Estratégico) desde o mapa do presidente até os níveis intermediários.

As metas dos níveis intermediários são denominadas iniciativas estratégicas.

Existem dois métodos para se desdobrar uma diretriz (CAMPOS , 1996): 
Método A - Consiste em que para cada nível e para cada meta sejam estabelecidas medidas para o seu atingimento e a partir destas medidas originam-se as metas dos níveis inferiores. Este método é mais simples e fácil de ser implementado, portanto deve ser sempre adotado para organizações iniciantes.

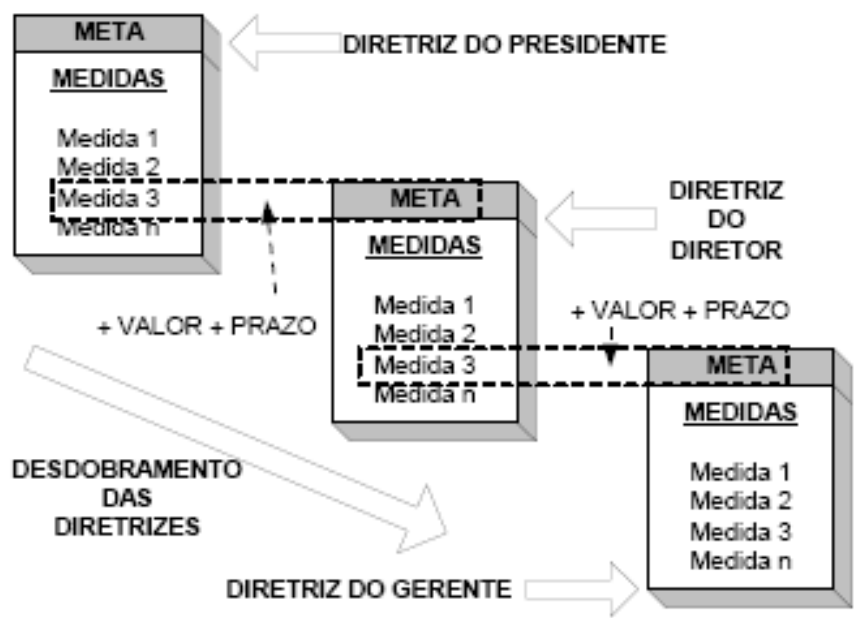

Figura 15 - Desdobramento das diretrizes pelo método $\mathrm{A}$

Fonte: Adaptado de Campos (1996)

Método B - Consiste em primeiro desdobrar as metas em todos os níveis hierárquicos e depois estabelecer as medidas em cada nível (mesmo que a organização comece pelo método $A$, é aconselhável que ao longo do tempo vá se aproximando do método B), conforme apresentado na Figura 16.

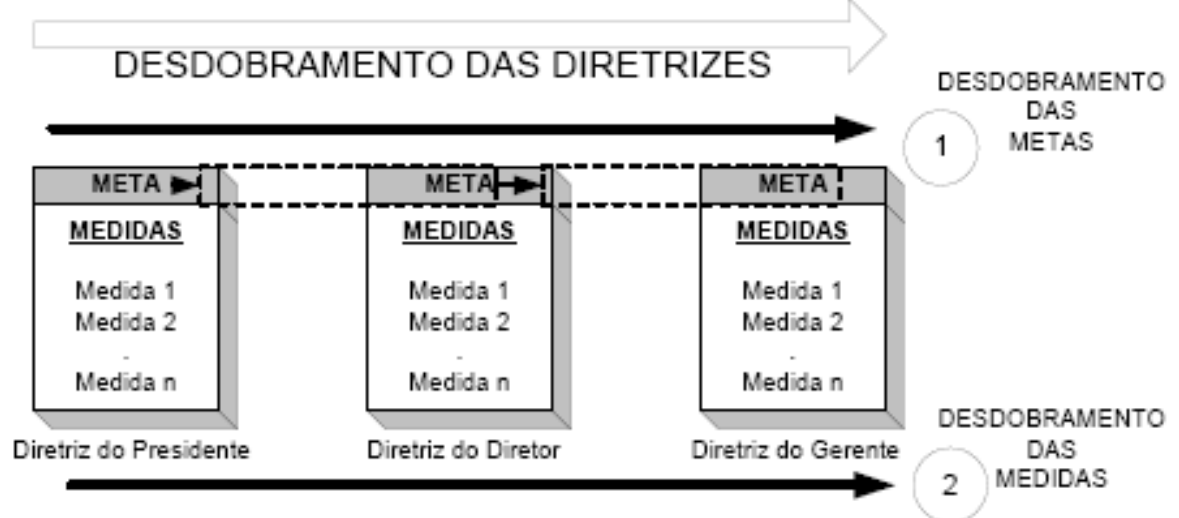

Figura 16 - Desdobramento das diretrizes pelo método $B$

Fonte: Adaptado de Campos (1996) 
Considerando-se que o mapa estratégico do BSC é composto por Objetivos estratégicos em diferentes perspectivas, realiza-se o seu desdobramento dos mesmos em iniciativas estratégicas nas mesmas perspectivas do mapa hierarquicamente superior.

Para realizar este desdobramento adota-se outro elemento da metodologia "Hoshin Kanri" conhecido como "Catchball". A abordagem "Catchball" está ligada à premissa de que todas as pessoas responsáveis pela execução de um objetivo estratégico devem participar da elaboração do mesmo. E esta premissa esta fundamentada na definição de que qualquer objetivo que envolva diálogo de grupo torna-se mais forte. O objetivo é obter alinhamento entre todas as posições dos grupos, focalizando a empresa como um sistema global alinhado com os seus objetivos essenciais (AKAO, 1997).

\subsection{Estudo das Relações de Causa e Efeito}

Os indicadores levantados não devem estar relacionados com metas estanques como qualidade, satisfação dos clientes, inovação ou empowerment dos funcionários. Evidentemente estas metas podem levar a um melhor desempenho da unidade de negócios, contudo, esse incremento dificilmente ocorrerá se tais metas forem consideradas um fim em si mesmo. Para tanto é necessário que as relações causais de todas as medidas incorporadas ao scorecard estejam vinculadas a objetivos financeiros. Um esquema da cadeia de relações indicador é apresentado na Figura 17. 


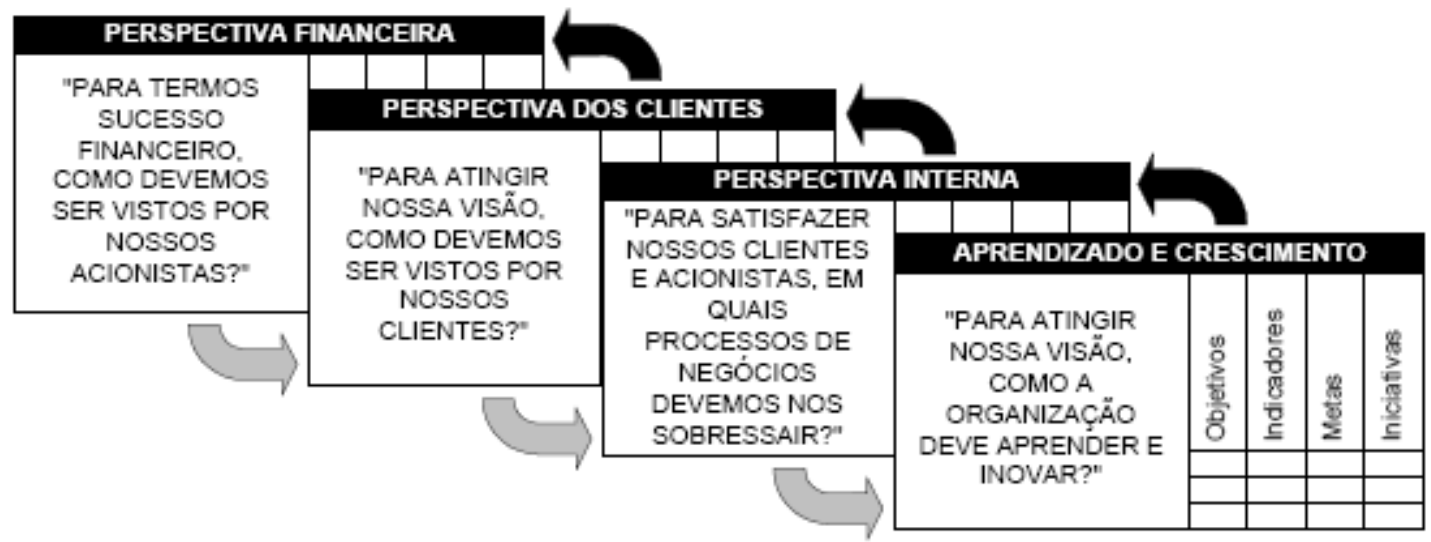

Figura 17 - Cadeia de relações entre os indicadores das diferentes perspectivas Fonte: adaptado de Kaplan \& Norton (1992)

\subsection{Identificação dos Pontos Fortes e Pontos Fracos}

$\mathrm{Na}$ seqüência deve ser realizada uma discussão quanto aos pontos fortes e pontos fracos da empresa, se possível, estabelecendo estes pontos a partir do contexto de mercado em que a empresa está inserida. Pontos fortes são aqueles que contam como um diferencial a favor da empresa, ao situá-la esta frente aos seus concorrentes de mercado. São exemplos de ponto forte: equipe motivada, facilidade de obtenção de recursos financeiros, etc. Pontos fracos consistem exatamente no oposto de pontos fortes. São exemplos de pontos fracos: mau entrosamento da equipe, falta de apoio à tomada de decisão, etc. Espera-se que a identificação prévia dos pontos fortes e fracos auxilie na determinação das iniciativas estratégicas, visto que, a discussão dos mesmos leva a uma reflexão quanto às deficiências e potencialidades da empresa no alcance de sua visão.

\subsection{Levantamento das Iniciativas Estratégicas}

A partir da definição dos pontos fortes e fracos obtidos na etapa anterior e utilizando-se a técnica de "Brainstorming" parte-se para levantamento das iniciativas estratégicas. 
As iniciativas estratégicas são obtidas por meio do questionamento "Através de qual iniciativa posso melhorar este ponto fraco?" e "Qual iniciativa estratégica me permite melhorar este ponto forte?".

A partir do estabelecimento das iniciativas estratégicas parte-se para a próxima etapa onde as mesmas serão priorizadas ou descartadas.

\subsection{Priorização das Iniciativas Estratégicas}

$\mathrm{Na}$ seqüência das iniciativas estratégicas identificadas, devem ser relacionadas com os objetivos estratégicos da gerência através de uma estrutura matricial, de tal modo que, o final obtenha-se as iniciativas prioritárias a serem alcançados para satisfazer a visão e a missão da empresa.

O preenchimento da matriz de priorização dos objetivos deve ser realizado da seguinte forma:

1. Preenche-se a coluna à esquerda da matriz com os objetivos estratégicos da gerência.

2. A cada objetivo estratégico pode-se atribuir um peso que reflete sua importância relativa, porém, com freqüência este procedimento não se faz necessário. Desta forma a coluna dos pesos fica preenchida com o número 1 em todas as linhas.

3. No cabeçalho da matriz colocam-se as iniciativas estratégicas.

4. A seguir é feito o preenchimento do corpo da matriz. O preenchimento é executado fazendo-se a seguinte pergunta para cada iniciativa: "Em que nível a iniciativa estratégica afeta o objetivo estratégico em questão?". Para cada iniciativa estratégica faz-se a mesma pergunta em relação a todos os objetivos estratégicos. A pergunta é respondida através de uma atribuição de pontos 
realizada conforme a Tabela 8 . Cabe ressaltar que podem ser utilizados números intermediários aos da tabela, que reflete a intensidade do relacionamento (lij) entre a iniciativa e o objetivo estratégico.

\begin{tabular}{c|c}
\hline Como a iniciativa estratégica afeta o objetivo estratégico? & Pontuação \\
\hline A iniciativa estratégica não afeta o objetivo estratégico & 0 \\
\hline A iniciativa estratégica afeta pouco o objetivo estratégico & 3 \\
\hline A iniciativa estratégica afeta moderadamente o objetivo estratégico & 6 \\
\hline A iniciativa estratégica afeta totalmente objetivo estratégico & 10 \\
\hline
\end{tabular}

Tabela 8 - Pontuação utilizada para o preenchimento do corpo da matriz

O índice de priorização das iniciativas estratégicas (IPij) é calculado pela intensidade de relacionamento (lij). A equação a ser utilizada para o cálculo do IPij é:

$$
I P i j=\sum_{i=1}^{n} P I x l i j \quad \text { Equação } 1
$$

Como resultado do preenchimento da matriz obtém-se as iniciativas estratégicas que deverão ser tratadas prioritariamente. Na Figura 18 é apresentado um esquema da matriz utilizada para esta priorização. 


\begin{tabular}{|c|c|c|c|c|c|}
\hline \multicolumn{2}{|c|}{$\begin{array}{c}\text { Em que nivel a iniciativa } \\
\text { estratégica pode ajudar a } \\
\text { alcançar o Objetivo Estratégico? }\end{array}$} & $\begin{array}{c}\text { iniciativa } \\
\text { estratégica } \\
1 \\
\end{array}$ & $\begin{array}{c}\text { iniciativa } \\
\text { estratégica } \\
2 \\
\end{array}$ & $\begin{array}{c}\text { iniciativa } \\
\text { estratégica } \\
3 \\
\end{array}$ & $\begin{array}{c}\text { iniciativn } \\
\text { estratégica } \\
4 \\
\end{array}$ \\
\hline Obje tivo Estratégico 1 & $P_{1}$ & $I i_{11}$ & $I i_{12}$ & $I i_{13}$ & $I i_{14}$ \\
\hline Objetivo Estratégico 2 & $P_{2}$ & $I i_{21}$ & $\mathrm{Ii}_{22}$ & $\mathrm{H}_{23}$ & $I i_{24}$ \\
\hline Objetivo Estratégico 3 & $P_{3}$ & $I i_{31}$ & $I i_{32}$ & $\mathrm{Ii}_{33}$ & $\mathrm{Ii}_{34}$ \\
\hline Obje tivo Estratégico 4 & $P_{4}$ & $I i_{41}$ & $\mathrm{Ii}_{42}$ & $\mathrm{Ii}_{43}$ & $I i_{44}$ \\
\hline & & $\sum_{i=1}^{n}\left(P_{i} x\right.$ & $\sum_{i=1}^{n}\left(P_{i} \times i_{i 2}\right)$ & $\sum_{i=1}^{n}\left(P_{i} \times i_{i 3}\right)$ & $\sum_{i=1}^{n}\left(P_{i} \times i_{i 4}\right)$ \\
\hline
\end{tabular}

Figura 18 - Matriz de priorização dos objetivos

A partir dos valores obtidos para o índice de priorização (IPij) utiliza-se o princípio de pareto para priorizar as iniciativas estratégicas mais importantes e descartar as que têm menor impacto na realização dos objetivos estratégicos.

\subsection{Estabelecimento dos Indicadores Operacionais e Estratégicos}

Nesta etapa, identifica-se um ou mais indicadores para cada iniciativa estratégica. $\mathrm{O}$ correto estabelecimento dos indicadores é fundamental para permitir o gerenciamento do processo. Esses indicadores constituem os itens de controle da direção.

O conjunto de indicadores deve ser completo e definido com parcimônia. Completo significa que eles devem ser suficientes para permitir a avaliação dos progressos em relação a todos os objetivos. Parcimônia refere-se ao aspecto que o número de indicadores não deve ser excessivo. É um erro definir um grande número de indicadores, muitos deles superpostos; isso apenas dificultaria o gerenciamento (RIBEIRO; CATEN; FRITSCH, 1998). 
Segundo Ribeiro; Caten; Fritsch (1998), a definição dos indicadores pode ser feita em uma reunião entre a gerência e as divisões, onde se busca responder às seguintes questões:

- Que indicadores podem ser utilizados para a iniciativa de modo a permitir seu monitoramento e servirem eficazmente como orientação ao posterior estabelecimento de ações?

- Existe superposição entre os indicadores listados? Em caso positivo, eliminar alguns dos indicadores, mantendo aqueles que são mais apropriados e mais fáceis de serem monitorados.

- Os indicadores restantes para a iniciativa são apropriados e suficientes para fins de monitoramento de seu sucesso? Em caso negativo, substituir ou acrescentar novos indicadores.

É importante que a equipe consiga classificar os diferentes tipos de indicadores de acordo com suas características. O número de possibilidades de classificações dos tipos de indicadores de desempenho é bastante grande. Contudo, de uma forma geral, eles podem ser classificados em indicadores qualitativos ou de atributos e indicadores quantitativos ou de variáveis. $O$ indicador qualitativo indica o juízo de valor e pode contar com o auxílio de um critério do tipo sim ou não, passa ou não passa, aceita ou rejeita. $O$ indicador quantitativo relata um processo empresarial a partir da coleta de valores numéricos representativos do processo considerado.

Os indicadores podem ter diferentes comportamentos ao longo do tempo, podendo ser cíclicos, de tendência linear crescente ou decrescente. Um indicador de comportamento cíclico é aquele que resulta de mudanças sistemáticas do ambiente externo, como a temperatura ou a fadiga de um operador. O comportamento linear (crescente ou decrescente) apresenta-se em situações como reações químicas que evoluem, desgastes de ferramentas, etc. Esta classificação auxilia na análise do 
indicador e na formulação da sua meta. Além desta, outra característica importante da qualidade do indicador é se o dado medido é do tipo menor-é-melhor, nominal-é-melhor ou maior-é-melhor (RIBEIRO; CATEN; FRITSCH, 1998).

É usual também classificar indicadores em operacionais, táticos e estratégicos. Tradicionalmente, utilizando-se a metáfora da pirâmide, o medidor operacional, associase às pessoas da base que executam, o tático às pessoas do meio que controlam e o estratégico às pessoas do tipo que pensam.

Ainda, é possível classificar os indicadores em dois tipos: os absolutos e os relativos, também chamados de índices. O primeiro grupo de indicadores corresponde às medidas absolutas, financeiras ou não-financeiras. O lucro, por exemplo, é um indicador financeiro absoluto das empresas. Já o volume de vendas é um indicador não-financeiro absoluto de desempenho. Indicadores relativos, ou índices, é resultado da comparação de duas medidas e são muito utilizados na análise de balanços (RIBEIRO; CATEN; FRITSCH, 1998).

\subsection{Estabelecimento das Metas e Especificações para cada Indicador}

Após a identificação dos indicadores para as iniciativas, o próximo passo é o estabelecimento das metas para cada indicador.

A definição das metas permite que todos entendam claramente quais os resultados esperados em relação a cada indicador. Para auxiliar na definição das metas, podem ser usados os resultados de um benchmarking, diagramas matriciais ilustrando comparações com a concorrência, gráficos de desempenho histórico, etc. A ferramenta a ser utilizada varia, conforme cada caso. Entretanto, é importante coletar e analisar todas as informações disponíveis. A análise deve compreender passado, presente e futuro, considerando as diretrizes de longo e médio prazo, a demanda dos clientes, a situação atual, etc. 
Há indicadores para os quais não se consegue estabelecer uma meta numérica. Nestes casos é imprescindível que se esclareça a situação futura desejada.

Finalmente, os objetivos e seus respectivos indicadores e metas devem ser avaliados criticamente em relação aos seguintes aspectos: (I) Está claro para todos?; (ii) Pode ser medido?; (iii) Representa um desafio?; (iv) É exeqüível?; (v) São coerentes entre si?

Os indicadores a serem monitorados devem ser detalhados quanto ao (i) tipo de meta apresentado (nominal-é-melhor, maior-é-melhor ou menor-é-melhor), (ii) unidade de medição e (iii) especificações operacionais ou de projeto.

Indicadores do tipo nominal-é-melhor possuem uma meta dada por um número real diferente de zero. Desvios da meta implicam em perdas de qualidade no processo ou produto acabado. Associados a esses indicadores definem-se limites inferior e superior de especificação, além dos quais os indicadores são considerados nãoconformes.

Indicadores do tipo maior-é-melhor possuem meta infinita. Esses indicadores não possuem limite superior de especificação, mas apenas um limite inferior a partir do qual os indicadores são considerados não-conformes. Indicadores do tipo menor-é-melhor possuem meta igual a zero. Esses indicadores não possuem limite inferior de especificação, mas apenas limite superior a partir do qual os indicadores são considerados não-conformes.

\subsubsection{Distribuição de indicadores do tipo nominal-é-melhor}

Neste caso os indicadores tendem a apresentar uma distribuição de probabilidade aproximadamente simétrica, pois as causas de variabilidade geram valores que podem se afastar tanto para cima como para baixo do alvo (Ex.: 
características dimensionais). Elas apresentam limites de especificação superior e inferior, conforme Figura 19.

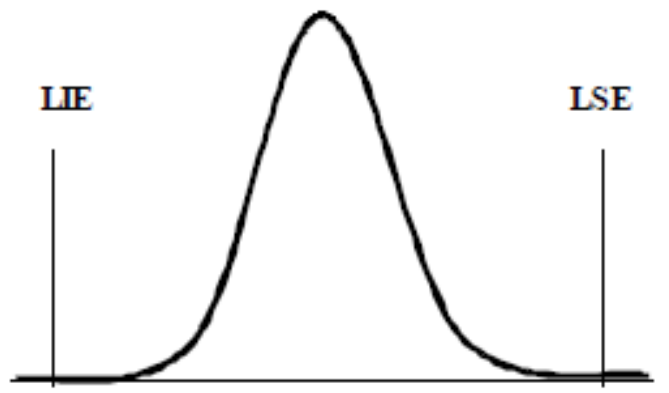

Figura 19 - Esquema de uma distribuição simétrica (nominal-é-melhor) com limite inferior e superior

Fonte: adaptado de (RIBEIRO; CATEN; FRITSCH, 1998)

\subsubsection{Distribuição de indicadores do tipo maior-é-melhor}

Os indicadores do tipo maior-é-melhor apresentam uma tendência a apresentar uma distribuição de probabilidade assimétrica à esquerda, pois muitas vezes existem limitações tecnológicas que dificultam a obtenção de valores altos, enquanto que muitas causas de variabilidade podem gerar valores baixos (Ex.: resistência mecânica). Elas apresentam apenas limite inferior de especificação, conforme Figura 20.

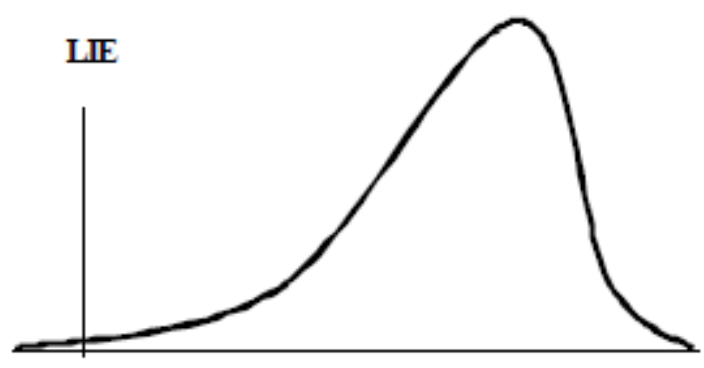

Figura 20 - Esquema de uma distribuição assimétrica à esquerda (maior-é-melhor) com limite inferior

Fonte: adaptado de (RIBEIRO; CATEN; FRITSCH, 1998) 


\subsubsection{Distribuição de indicadores do tipo menor-é-melhor}

Indicadores do tipo menor-é-melhor tendem a apresentar uma distribuição de probabilidade assimétrica à direita, pois muitas vezes existem limitações tecnológicas dificultando a obtenção de valores baixos, enquanto que muitas causas de variabilidade podem gerar valores altos (Ex.: nível de ruído). Elas apresentam apenas limite superior de especificação, conforme Figura 21.

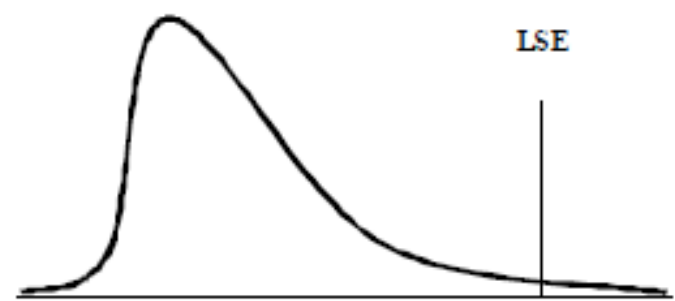

Figura 21 - Esquema de uma distribuição assimétrica à direita (menor-é-melhor) com limite superior

Fonte: adaptado de (RIBEIRO; CATEN; FRITSCH, 1998)

Cada meta deve ser compatível com as possibilidades do grupo. Ela deve desafiar o grupo, exigindo a mobilização de esforços, exigindo o máximo de cada setor. Contudo, é um erro estabelecer metas inalcançáveis. Metas inalcançáveis, ao invés de desafiarem o grupo acabam por desencorajá-lo.

\subsubsection{Definição pelos responsáveis pela coleta de dados e ações corretivas}

Nessa etapa é necessário definir os responsáveis pela coleta dos dados, registro e apresentação de indicadores em reunião gerencial. Também se definem responsáveis pelas ações corretivas, no caso do processo sair fora do controle, e ações preventivas para evitar a reincidência do problema. 


\subsubsection{Identificação dos resultados essenciais (indicadores de ocorrência) e dos vetores de desempenho (indicadores de tendência)}

Toda a medida selecionada para um Balanced Scorecard deve ser um elemento de uma cadeia de relações de causa e efeito que comunique o significado da estratégia da unidade de negócios à empresa. Um bom BSC deve ser uma combinação adequada de resultados essenciais (indicadores de ocorrências) e vetores de desempenho (indicadores de tendência) ajustados à estratégia da unidade de negócios. Para tanto é necessário que se tenham um entendimento claro do que significa cada uma destas medidas.

Os indicadores de ocorrências consistem em medidas mais genéricas de resultados, costumando aparecer com freqüência até mesmo nas estratégias também das outras organizações (empresas concorrentes). São exemplos de indicadores de ocorrência a lucratividade, participação de mercado, satisfação de clientes e retenção de clientes. Os indicadores de ocorrência sozinhos, sem os indicadores de tendência, não comunicam a maneira como os resultados devem ser alcançados, além de não indicarem antecipadamente se a implementação da estratégia está sendo bem sucedida ou não.

Os indicadores de tendência, por sua vez, costumam ser mais específicos para cada unidade de negócios. Eles refletem a singularidade da estratégia da unidade de negócios. São exemplos de indicadores de tendência, o percentual de processos padronizados ou número de treinamentos de funcionários.

\subsection{Geração de Resultado do Modelo Proposto}

Conforme Campos (2009), em seu livro O Verdadeiro Poder, o desdobramento através do gerenciamento pelas diretrizes torna-se fundamental para garantir que os indicadores e metas de cada nível hierárquico estejam interligados, desde a diretoria até o nível operacional da empresa, e a linguagem deve mudar em cada nível, partindo 
de um indicador estratégico, passando por um indicador geral, até um indicador operacional e atuável, sendo que os valores das metas devem estar matematicamente interligados.

Para completar o modelo, espera-se como resultado, a geração de um Farol de Nível de Serviço - FNS, conforme exposto na figura 22, com indicadores operacionais essenciais para o desempenho de uma empresa, e a descrição detalhada de cada indicador consolidada em um dicionário.

\section{FAROL DE NIVEL DE SERVIÇO - FNS}
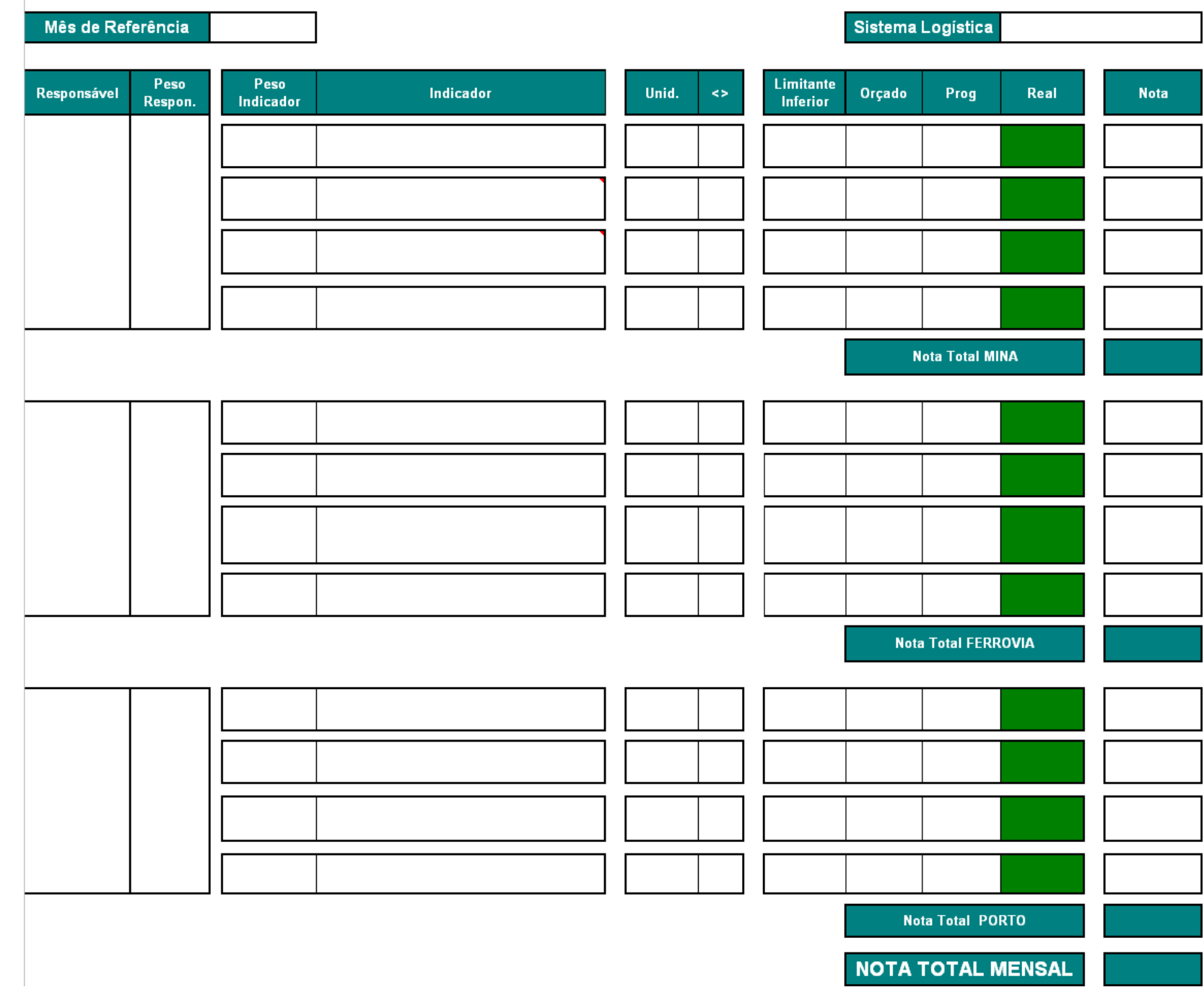

Figura 22 - Farol de Nível de Serviço - FNS 


\subsection{Acompanhamento e Consolidação}

A partir da avaliação da sistemática de implantação através do fluxo das etapas, analisa-se o sistema implantado, verificando a eficiência dos procedimentos de coleta de dados, registro e ação. Identificam-se eventuais deficiências e planeja-se o aprimoramento do sistema. A análise do sistema deve ser feita em conjunto com as pessoas envolvidas na implantação (gerentes, engenheiros, supervisores e operadores).

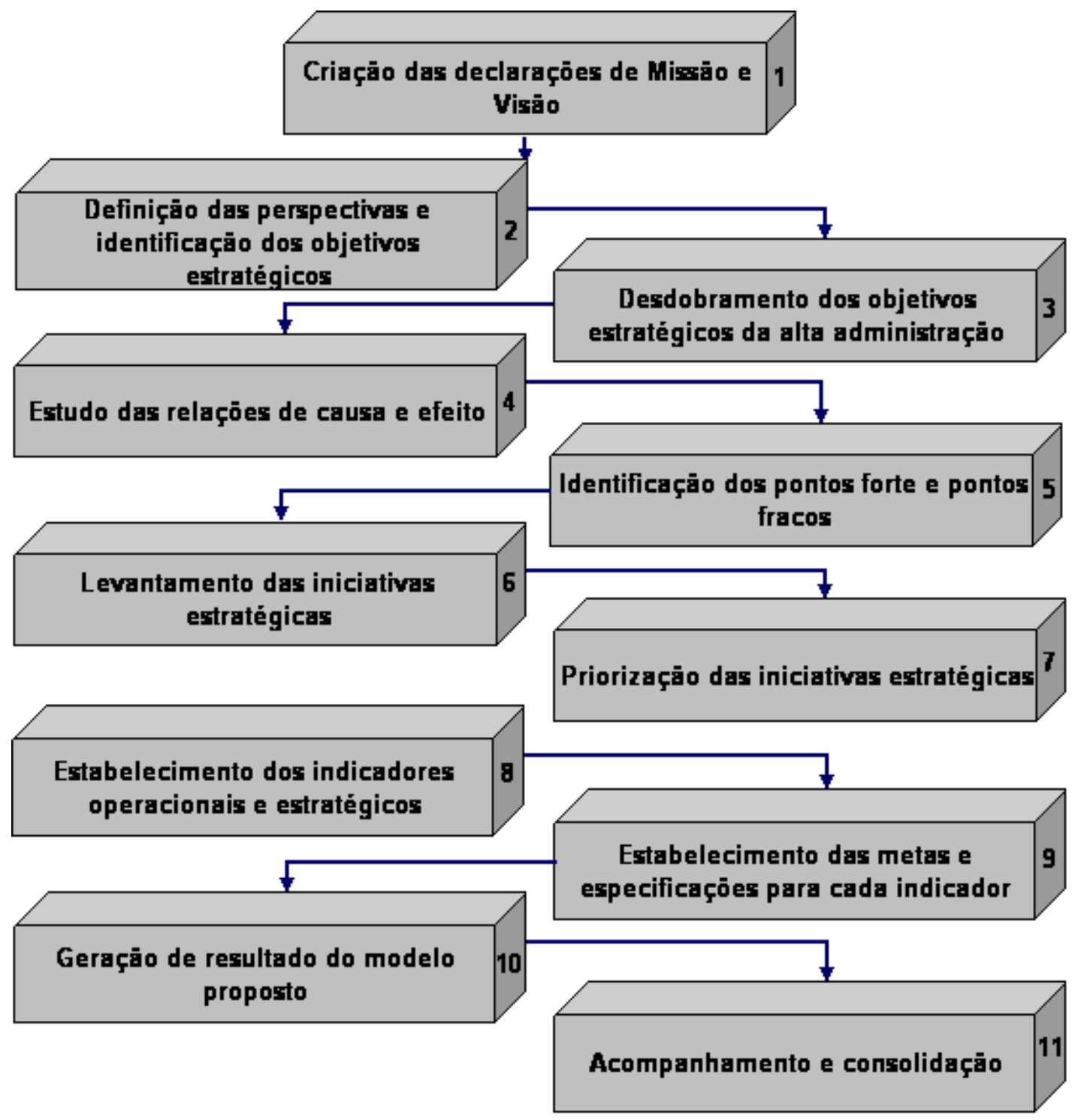

Figura 23 - Fluxo das etapas de implantação do sistema de indicadores 


\section{CAPÍTULO 4 - IMPLANTAÇÃO DO SISTEMA DE INDICADORES DE DESEMPENHO}

Neste capítulo descreve-se a aplicação do sistema de indicadores de desempenho no departamento de logística de uma empresa de mineração.

O departamento de logística é composto por 3 diretorias principais: comercial, planejamento e operação. A implantação do sistema de indicadores de desempenho foi desdobrada desde a alta gerência até o nível operacional do departamento

Inicialmente, a equipe responsável pela implantação do sistema de indicadores analisou o relacionamento do departamento de logística com os demais departamentos da organização, considerando-se ainda a estrutura funcional. O objetivo desta atividade foi conhecer: (I) os objetivos financeiros estabelecidos para o departamento; (ii) os temas coorporativos primordiais; (iii) relações com outros departamentos. Desta forma a equipe esperava poder situar o departamento dentro da organização e, com isso, criar uma visão e missão, iniciativas estratégicas e indicadores, todos alinhados aos objetivos estratégicos da organização.

\subsection{Criação das Declarações da Missão e da Visão}

Ao declarar a missão e a visão, apontou-se em ambas as declarações as crenças essenciais, e identificou-se quais os mercados-alvo do departamento. No intuito de fornecer motivação para o departamento tentou-se ainda buscar declarações de missão e visão que fossem inspiradoras, uma vez que, elas representariam para o departamento de logística a razão de sua existência.

No caso da declaração da missão, foi identificado claramente o propósito da empresa tomando-se o devido cuidado para que este propósito tivesse o seu grau de abstração devidamente delimitado. Já no caso da visão, foram seguidas algumas orientações, sendo elas: (I) retratar um estado futuro desejado; (ii) ser de longo prazo; (iii) ter uma descrição clara; (iv) estar alinhada com os valores centrais da empresa; ( $v$ ) 
ser inspiradora e impulsionadora; ( $v i)$ prover focalização e alinhamento; ( vii) rescindir de maiores explicações e; (viii) confrontar padrões atuais. Tanto a missão quanto a visão foram estabelecidas por um grupo menor de pessoas, sendo posteriormente discutidas com todos os funcionários do departamento e, por fim, ajustadas de tal modo que resultassem em textos claros, concisos e devidamente alinhados ao propósito geral da organização.

Deve-se salientar que para se obter o efetivo envolvimento de toda equipe de logística na elaboração da missão e visão foi montada uma reunião com membros do departamento fora da empresa. Esta reunião contou com a presença da área de gestão da qualidade para auxiliar na sensibilização dos membros do departamento, buscando assim obter um desenvolvimento do senso de equipe, de modo a obter uma performance superior no resultado. Como resultado obteve-se as seguintes declarações:

Missão: "Prover as melhores solucões logísticas para gerar vantagens competitivas para seus clientes".

Visão: "Ser reconhecida pelos mercados onde atua como o mais seguro e eficiente prestador de servicos logísticos até 2010".

\subsection{Definição das Perspectivas e Identificação dos Objetivos Estratégicos para as mesmas}

O Mapa estratégico da direção da empresa foi desenvolvido a partir do planejamento estratégico da Companhia, o qual foi executado em conjunto com a área de gestão de qualidade, com a presença do diretor comercial, do diretor de planejamento e do diretor de operações. 
A partir do Planejamento Estratégico da empresa foi inicialmente desenvolvido o mapa estratégico do diretor executivo de logística com o estabelecimento dos objetivos estratégicos, conforme as quatro perspectivas padrões do BSC: (I) perspectiva financeira; (ii) perspectiva dos clientes; (iii) perspectiva dos processos internos; (iv) perspectiva do aprendizado e crescimento.

\subsection{Desdobramento dos Objetivos Estratégicos da Alta Administração}

A partir do mapa estratégico do diretor executivo de logística definido pelo colegiado de diretores cada diretoria reuniu seu grupo de gerentes gerais e partiu para o desdobramento dos objetivos estratégicos deste mapa estratégico segundo suas áreas afins.

No caso específico da diretoria de operações logísticas, diretoria à qual o departamento de logística se reporta e sobre o qual este trabalho versa de modo mais específico, foi realizada 3 reuniões com a presença dos consultores externos e com a presença de todos os gerentes gerais desta diretoria.

Os objetivos da diretoria executiva de logística foram desdobrados nos objetivos estratégicos da diretoria de operações logísticas a partir de cinco perspectivas: (I) perspectiva financeira; (ii) perspectiva dos clientes; (iii) perspectiva dos processos internos; (iv) perspectiva do aprendizado e crescimento e; (v) perspectiva regulatória. É importante ressaltar que foi utilizada uma perspectiva a mais do que o modelo padrão do BSC devido à importância da agência reguladora no negócio e a relevância desta perspectiva para as ações da diretoria de operações logísticas.

As reuniões foram importantes na medida em que houve envolvimento de toda a gerência criando-se maior comprometimento na realização dos objetivos estratégicos da diretoria e também porque o envolvimento da gerência no desdobramento dos objetivos da diretoria executiva para a diretoria de operações logísticas subsidiou o próximo passo que é o desdobramento dos objetivos da diretoria para as gerências. 
Sendo assim, conforme apresentado no Capítulo 2 e no Capítulo 3, adotou-se práticas do modelo "Hoshin Kanr" para desdobrar os objetivos estratégicos, à semelhança dos desdobramentos de diretrizes do mesmo.

\subsection{Estudo das Relações de Causa e Efeito entre as Perspectivas para os Objetivos Estratégicos}

O passo seguinte consistiu em elaborar um mapa estratégico com base nos objetivos estratégicos levantados pela alta gerência. Este mapa estratégico foi elaborado relacionando os objetivos estratégicos entre si numa lógica de causa e efeito e, distribuindo-os nas perspectivas.

O processo de determinação das relações de causa-e-efeito do mapa estratégico da gerência também foi realizado com os gerentes de área do departamento e a área de gestão de qualidade (processos).

A metodologia para determinar a relação de causa-e-efeito consistiu em primeiro colocar no mapa estratégico os objetivos estratégicos da perspectiva financeira, os quais são os objetivos fins da empresa.

Após partiu-se para a pergunta "O objetivo estratégico $\mathrm{X}$ influencia no objetivo estratégico Y?". Se sim, estabelece-se uma ligação entre ambos significando que a relação entre ambos tem uma relação de causa-e-efeito. A partir da perspectiva financeira construiu-se o mapa ligando-se os objetivos estratégicos entre as perspectivas até chegar na perspectiva de aprendizagem e crescimento que dará sustentação para no futuro o departamento manter/criar vantagem competitiva duradoura. 


\subsection{Identificação dos Pontos Fortes e Pontos Fracos}

$\mathrm{Na}$ seqüência foi realizada a definição dos pontos fortes e pontos fracos do departamento, estabelecendo estes pontos a partir do contexto de mercado em que o departamento está inserido. Os pontos fortes e fracos, aliados a missão e visão do departamento, serviram de embasamento para definição das iniciativas estratégicas.

Para definição dos pontos fortes e fracos e das iniciativas estratégicas foi primeiramente realizado um encontro de todo departamento de logística. Como preparação para discussão e definições foi realizada atividades de vivência e jogos, com vistas à integração do grupo e desenvolvimento de visão sistêmica. Este encontro foi ministrado pela área de gestão de qualidade e recursos humanos, e as seguintes atividades foram desenvolvidas:

- Apresentação do grupo: onde cada componente apresentou-se ressaltando estrutura familiar, fatores de motivação e hobbys.

- Trabalho de análise transacional para identificar os papéis que cada um exerce em seus relacionamentos diários. Neste trabalho percebeu-se a dificuldade de relacionamentos quando existe a falta de objetivos claros, o que leva a necessidade de planejamento estratégico.

- Trabalho de sensibilização da equipe, seguida por uma dinâmica para definição dos pontos fortes de cada componente da equipe pelos seus colegas.

O objetivo principal destas dinâmicas foi preparar a equipe para iniciar a definição dos pontos fortes e fracos e iniciativas estratégicas com uma visão sistêmica e de integração de equipe. Após esta dinâmica foi realizada uma reunião para: (I) identificação dos pontos fracos e fortes; (ii) discutir as 5 perspectivas e questões correlacionadas; (iii) identificar iniciativas estratégicos para cada uma das 
perspectivas. Esta reunião também foi coordenada pela gestão e qualidade e $\mathrm{RH}$. Todos os 3 itens foram definidos através de brainstorming.

\subsection{Levantamento das Iniciativas Estratégicas}

Em seguida, a equipe do departamento de logística estabeleceu as iniciativas estratégicas com foco maior no desempenho. Para tanto, se utilizou uma perspectiva a mais do que aquelas utilizadas pela alta gerência, sendo ela, a perspectiva de segurança.

As iniciativas estratégicas foram estabelecidas a partir da missão e visão e dos pontos fortes e fracos, o que permitiu as mesmas ficarem coerentes entre si e ficarem de acordo com os objetivos da empresa. Durante a elaboração das iniciativas estratégicas, a equipe perguntava se cada iniciativa sugerida estaria auxiliando o departamento a alcançar sua visão cumprindo sua missão, ou não.

Como resultado da reunião obteve-se um total de vinte e duas iniciativas estratégicas, distribuídas em seis perspectivas. Estas iniciativas estratégicas foram posteriormente avaliadas por um grupo menor, objetivando-se realizar eventuais correções e ajustes. 


\begin{tabular}{|c|c|}
\hline \multirow{4}{*}{ 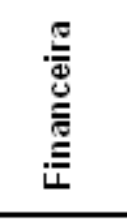 } & Obter custo de operaçẫo menor que a concorrência \\
\hline & Reduzir o custo de estoque, garantindo o nível de serviço \\
\hline & Melhorar sistema de avaliaçẫo financeira de projetos de logística \\
\hline & Preços competitivos suportados pelo relacionamento com os clientes \\
\hline \multirow{4}{*}{ 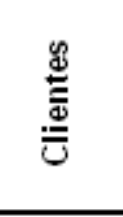 } & Aumentar market share na área de atuaçẫo \\
\hline & Inserir novos serviços \\
\hline & Melhorar o foco nos clientes pequenos \\
\hline & Promover evento específico para apresentar os novos investimentos \\
\hline \multirow{5}{*}{ 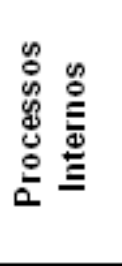 } & Continuidade na estabilização dos processos internos \\
\hline & Fortalecer o relacionamento com as interfaces \\
\hline & Reduzir turnover de gerentes e especialistas \\
\hline & Cumprimento das premissas para alcance dos objetivos/metas \\
\hline & Mensurar os ganhos com a implantaçẫo da nova ferramenta de gestẫo de estoque \\
\hline \multirow{4}{*}{ 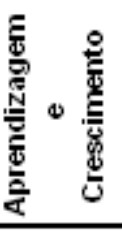 } & Manter o investimento contínuo em tecnologias \\
\hline & Aumentar o intercâmbio entre os sites \\
\hline & Cumprir a grade de treinamento dos funcionários \\
\hline & Investir tempo para conhecer melhor os concorrentes e os clientes \\
\hline \multirow{2}{*}{ 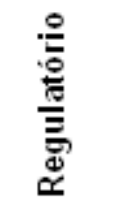 } & Atender às exigências regulatórias para funcionamento das operaçỗes \\
\hline & Cumprir as demandas da agências regulatórias para implantaçẫo de novos projetos \\
\hline \multirow{3}{*}{ 总 } & Atender às normas de segurança \\
\hline & Mapear os pontos de riscos das áreas \\
\hline & Intensificar campanhas de segurança \\
\hline
\end{tabular}

Tabela 9 - Relação das iniciativas estratégicas levantadas

No que se refere à discussão dos fatores críticos de sucesso do método proposto para implantação do sistema de indicadores de desempenho, percebeu-se que a etapa de identificação dos pontos fortes e pontos fracos mostraram-se especialmente importante para a implementação do sistema de indicadores de desempenho. A equipe do departamento, ao reunir-se para eleger os seus pontos fortes e pontos fracos, submeteu-se a uma reflexão profunda dos seus processos de trabalho e de seu 
desempenho. Ainda, a equipe adquiriu uma base sólida para a identificação de suas iniciativas estratégicas. Percebeu-se ainda que ao discutir as iniciativas estratégicas do departamento, a equipe envolvida na atividade acabou levantando questões de grande relevância. Por exemplo, pelo fato de funcionários de diferentes áreas do departamento de logística terem observado de forma interdisciplinar os problemas do departamento como um todo. Os mesmos acabaram por perceber necessidades, ora comuns entre áreas, ora bastante discrepantes, por decorrência das diferentes visões de processo existentes no mesmo departamento.

Outro fator importante a ser ressaltado é que a utilização de atividades de integração foi importante para motivar definições que avaliem os interesses globais do departamento e não apenas individuais relacionados apenas com as atividades de cada área e/ou componente do grupo.

A participação de todo grupo também foi importante por dois aspectos principais: (I) ampliar a visão do grupo no que se refere às dificuldades e oportunidades do departamento como um todo (ii) envolver todos na construção do planejamento estratégico do departamento, de forma que todos se sintam parte do mesmo e logo estejam mais motivados na busca das metas.

\subsection{Priorização das Iniciativas Estratégicas Melhor Alinhadas com os Objetivos Estratégicos}

Uma vez determinadas as iniciativas estratégicas do departamento, partiu-se para o estabelecimento de quais destas iniciativas estariam melhores alinhadas aos objetivos estratégicos da alta gerência.

Para a construção da matriz de priorização, montou-se um pequeno grupo que pontuou, em uma escala de 1 a 10, o quanto cada iniciativa estratégica contribuía para o alcance do objetivo estratégico. Com o somatório da pontuação de cada iniciativa estratégica, foi possível priorizá-las. Através desta atividade as iniciativas estratégicas 
críticas foram priorizadas, o que permite à empresa alcançar seus objetivos estratégicos com maior eficiência.

Como resultado desta priorização concluiu-se que quatorze iniciativas estratégicas deveriam ser mantidas, com o intuito de auxiliar a organização a alcançar seus objetivos estratégicos.

No que se refere à discussão dos fatores críticos de sucesso do método proposto para implantação do sistema gerencial, percebeu-se que o maior benefício oferecido por esta etapa, foi a percepção do quanto os objetivos gerenciais do departamento estavam alinhados ao que era esperado deste, pela alta gerência.

\subsection{Estabelecimento dos Indicadores Operacionais}

Uma vez estabelecidas as principais iniciativas estratégicas do departamento, foram determinados os indicadores operacionais a serem utilizados para ajudar a alcançar estas iniciativas. Para cada iniciativa estratégica foram estabelecidos um ou mais indicadores operacionais. Estes indicadores foram desdobrados conforme a necessidade de cada uma das áreas do departamento de logística.

$\mathrm{Na}$ definição dos indicadores operacionais foi levado em consideração o estabelecimento de indicadores que fossem também relevantes para acompanhamento da média e alta gerência.

Para cada indicador operacional foi estabelecido também, se o indicador era:

(i) do tipo atributo ou variável;

(ii) do tipo maior-é-melhor, nominal-é-melhor ou menor-é-melhor;

(iii) qual a periodicidade de obtenção dos dados;

(iv) unidades de leitura, meta e limites de especificação;

(v) qual a área responsável; 
(vi) onde seriam obtidos os dados (origem dos dados);

(vii) qual o processo de onde se originariam os dados;

(viii) qual o responsável pela obtenção dos dados;

(ix) qual a forma de apresentação dos dados e;

(x) qual a forma de cálculo do indicador.

É importante salientar que o departamento, até o momento da implementação do sistema de indicadores, trabalhava com 16 indicadores que tinham sido montados a partir de fatos isolados, e por isso não tinham a abrangência necessária para uma efetiva gestão. Sendo que estes indicadores estavam relacionados exclusivamente a perspectiva financeira do departamento, e que se tratavam de indicadores de ocorrência, não permitindo a gestão de o departamento inferir qual seria o desempenho futuro, pois os mesmos provinham apenas uma visão dos resultados passados.

Os indicadores operacionais foram definidos em reuniões realizadas com a gerência de área do departamento do qual a iniciativa estratégica estava relacionada. Estas reuniões foram feitas à semelhança do modelo de gestão "Hoshin Kanri", onde as metas eram negociadas entre a gerência e a supervisão até a obtenção de consenso, a semelhança da metodologia "Catchball".

Neste processo foram criados 50 (cinqüenta) indicadores, divididos entre as áreas do departamento. Cabe salientar que conforme apresentado na revisão bibliográfica, o número de indicadores habitualmente utilizados para o nível área/funcional deve-se situar em torno de 10 a 15 e para o nível individual até 5 indicadores de desempenho. Esta quantidade se reflete na quantidade de indicadores desenvolvidos para serem utilizados no departamento. 


\begin{tabular}{|c|c|}
\hline \multirow{8}{*}{ 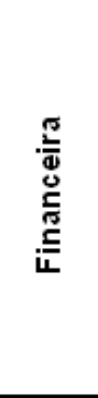 } & maximizaçẫo do custo do pacote logístico \\
\hline & redução do custo com óleo diesel \\
\hline & redução do número de reatracação de navios \\
\hline & reduçẫo da remoçẫo de produtos entre pátios \\
\hline & maximizaçẫo da ocupaçẫo dos pátios \\
\hline & retorno sobre o investimento \\
\hline & $\%$ desconto na tarifa do pacote logístico por contrato de longo prazo \\
\hline & maximizaçăo das tarifas $\times$ rotas por cliente \\
\hline \multirow{10}{*}{ 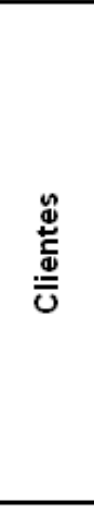 } & percentual de market share \\
\hline & aumento da participação de clientes chaves \\
\hline & número de novos projetos \\
\hline & volume embarcado para os clientes \\
\hline & $\%$ de venda de novos serviços para clientes pequenos \\
\hline & aderência ao volume da PV (previsẫo de vendas) em mercado externo por produto \\
\hline & aderência da taxa comercial de embarque dos navios \\
\hline & cadastro da instrução de embarque \\
\hline & percentual da carteira com clientes pequenos \\
\hline & número de eventos por segmento de atuação \\
\hline \multirow{17}{*}{ 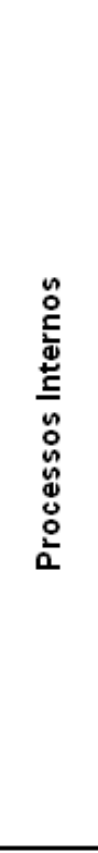 } & padronizaçã̃o de processos \\
\hline & implantação do FNS interno \\
\hline & aderência ao FNS \\
\hline & aderência da chegada dos trens no porto \\
\hline & peso médio do vagões carregados com Mfe \\
\hline & taxa do peneiramento \\
\hline & aderência da oferta para carga à programação $\mathrm{D}+30$ da oferta \\
\hline & ciclo total \\
\hline & cumprimento do programa $\mathrm{D}+30$ da descarga \\
\hline & OEE descarga de vagões \\
\hline & $\%$ de retençẫo de talentos \\
\hline & cumprimento do programa d+30 do carregamento \\
\hline & $\%$ de gerentes com adesão ao programa matching \\
\hline & $\%$ de premissas implantadas \\
\hline & aderência ao cumprimento das metas \\
\hline & aumento do giro de estoque \\
\hline & \% ocupação de pátio por equipamento \\
\hline \multirow{7}{*}{ 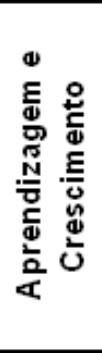 } & $\%$ de processos automatizados \\
\hline & retorno sobre o investimento da tecnologia implantada \\
\hline & $\%$ de funcionários treinados em sites benckmarking \\
\hline & $\%$ de funcionários de outros sites treinados em nosso site \\
\hline & $\%$ de realização dos treinamentos \\
\hline & número de visitas à clientes \\
\hline & número de visitas aos concorrentes \\
\hline
\end{tabular}




\begin{tabular}{|c|c|}
\hline \multirow{4}{*}{ 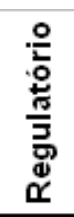 } & $\%$ de projetos com Ll expedida dentro do prazo \\
\hline & $\%$ de projetos com LO expedida dentro do prazo \\
\hline & $\%$ de pendências junto a ANTT \\
\hline & $\%$ de documentos expedidos dentro do prazo para ANTAQ \\
\hline \multirow{4}{*}{ 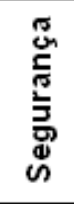 } & percentual de adequaçấo às RAC's \\
\hline & percentual de adequaçẫo às NR's \\
\hline & implantaçẫo de mapas de risco nas áreas \\
\hline & redução das taxas de acidentes \\
\hline
\end{tabular}

Tabela 10 - Relação dos indicadores operacionais

Um ponto importante a ser destacado, é que os indicadores foram criados para as seis perspectivas das iniciativas estratégicas, formando um conjunto de indicadores balanceados em detrimento aos indicadores anteriores com enfoque somente financeiro.

Nota-se a partir da observação da quantidade de indicadores por perspectivas a abrangência dos mesmos para o melhor acompanhamento da estratégia, em relação à situação anterior com um enfoque apenas na perspectiva financeira.

\subsection{Geração de Resultado do Modelo Proposto}

Devido à quantidade elevada de indicadores de desempenho que foram criados, e como os mesmos são acompanhados através de reuniões mensais, optou-se por dividir os indicadores em fixos e rotativos. Assim, determinou-se que os indicadores fixos serão acompanhados todos os meses do ano e os rotativos serão acompanhados em meses determinados.

Desta forma, cada responsável pelo indicador levanta e acompanha todos os seus indicadores a cada mês. No entanto, na reunião gerencial mensal serão apresentados apenas 12 indicadores de desempenho consolidados no Farol de Nível de Serviço, garantindo a apresentação de todos os indicadores ao longo do ano, sem contudo, tomar um tempo demasiado da referida reunião. 
Após a construção do Farol de Nível de Serviço, figura 24, chegou-se ao resultado de 12 indicadores operacionais definidos para serem acompanhados por um grupo de áreas da empresa de mineração, sendo esses indicadores extremamente importantes para integração e excelência operacional do sistema logístico no qual estas áreas estão inseridas.

FAROL DE NIVEL DE SERVIÇO - FNS

\begin{tabular}{|c|c|c|c|c|c|c|c|c|c|c|}
\hline \multicolumn{2}{|c|}{ Mês de Referência } & dez/2009 & \multirow[b]{2}{*}{ Indicador } & & & \multicolumn{3}{|c|}{$\begin{array}{c}\text { Sistema } \\
\text { Logistico }\end{array}$} & & \\
\hline Responsável & $\begin{array}{l}\text { Peso } \\
\text { Respon. }\end{array}$ & $\begin{array}{l}\text { Peso } \\
\text { Indicador }\end{array}$ & & Unid. & $\ll$ & $\begin{array}{l}\text { Limitante } \\
\text { Inferior }\end{array}$ & Orçado & Prog & Real & Nota \\
\hline \multirow{4}{*}{ Mina } & \multirow{4}{*}{$33,00 \%$} & $6,00 \%$ & Peso Médio Mfe (exceto pelotas) & ton / vagăo & $>$ & & & & & \\
\hline & & $9,00 \%$ & Cumprimento do programa $D+30$ do carregamento & lotes/dia & $>$ & & & & & \\
\hline & & $8,00 \%$ & Cadastro de instruçăa de embarque (meta $=72 \mathrm{~h}$ ) & $\%$ & $>$ & & & & & \\
\hline & & $10,00 \%$ & $\begin{array}{l}\text { Aderência ao volume da PV (previsão de vendas) em } \\
\text { mercado externo por produto. }\end{array}$ & $\%$ & $>$ & & & & & \\
\hline & & & & & & & \multicolumn{3}{|c|}{ Nota Total MINA } & \\
\hline \multirow{4}{*}{ Ferrovia } & \multirow{4}{*}{$34,00 \%$} & $7,00 \%$ & Ciclo Total & horas & $<$ & & & & & \\
\hline & & $10,00 \%$ & Aderência da chegada dos trens nos Portos Sul & $\%$ & $>$ & & & & & \\
\hline & & $8,00 \%$ & $\begin{array}{l}\text { Aderência da oferta para carga à programaçẫo D + } 30 \mathrm{da} \\
\text { oferta }\end{array}$ & $\%$ & $>$ & & & & & \\
\hline & & $9,00 \%$ & $\begin{array}{l}\text { Aderência da oferta para descarga à programação D + } \\
30 \text { da oferta }\end{array}$ & $\%$ & $>$ & & & & & \\
\hline & & & & & & & \multicolumn{3}{|c|}{ Nota Total FERROVIA } & \\
\hline \multirow{4}{*}{ Porto } & \multirow{4}{*}{$33,00 \%$} & $10,00 \%$ & Volume embarcado para os clientes & MMton & $>$ & & & & & \\
\hline & & $8,00 \%$ & Cumprimento do programa $\mathrm{D}+30$ da descarga & lotes/dia & $>$ & & & & & \\
\hline & & $7,00 \%$ & OEE Descarga & $\%$ & $>$ & & & & & \\
\hline & & $8,00 \%$ & Aderência da taxa comercial de embarque dos navios & $\%$ & $>$ & & & & & \\
\hline & & & & & & & & Total i & & \\
\hline & & & & & & & & $\begin{array}{l}\text { A TC } \\
\text { ENS }\end{array}$ & & \\
\hline
\end{tabular}

Figura 24 - Farol de Nível de Serviço com indicadores consolidados 
Para melhor entendimento e conhecimento dos indicadores de desempenho foi elaborado um dicionário em forma de tabela com a descrição detalhada dos indicadores de desempenho. A tabela 11 descreve os indicadores apresentados no Farol de Nível de Serviço da figura 24 .

\begin{tabular}{|c|c|c|c|c|c|c|c|c|c|}
\hline INDICADOR & OBJETIVO & RESPONSÁVEL & MÉTRICA & UN & LÓGICA & PESO & FONTE de DADOS & $\begin{array}{c}\text { PERIODICIDA } \\
\text { DE }\end{array}$ & $\begin{array}{l}\text { PONTO } \\
\text { FOCAL }\end{array}$ \\
\hline $\begin{array}{l}\text { Peso Médio Mfe (exceto } \\
\text { pelotas) }\end{array}$ & $\begin{array}{l}\text { Garantir máxima saturação dos } \\
\text { vagốes, em peso, para todo } \mathrm{MFe} \\
\text { carregado }\end{array}$ & Mina & $\begin{array}{l}\text { Peso Médio = volume carregado MFe / } \\
\text { quantidade de vagốes carregados MFe } \\
\text { (desconsiderar pelotas) }\end{array}$ & ton/vag & $>$ & $8,33 \%$ & $\begin{array}{l}\text { Planilha eletrônica no } \\
\text { diretório: } \\
\text { Informacoes_Gerenciais }\end{array}$ & Semanal & Mina \\
\hline $\begin{array}{l}\text { Cumprimento do programa } \\
D+30 \text { do carregamento }\end{array}$ & $\begin{array}{l}\text { Medir a aderência de carregamento } \\
\text { de MFe na mina conforme } \\
\text { programaçẫo } D+30\end{array}$ & Mina & $\begin{array}{l}\text { Dispersão }=\text { Média de Lotes carregados } \\
/ \text { Média de Lotes prog D+30 para } \\
\text { carregamento }\end{array}$ & lotes/dia & $>$ & $8,33 \%$ & $\begin{array}{l}\text { Planilha RD (ata reunião } \\
\text { diária), planilha } \mathrm{D}+30\end{array}$ & Semanal & Mina \\
\hline $\begin{array}{l}\text { Cadastro de instruçẫo de } \\
\text { embarque (meta }=72 \mathrm{~h})\end{array}$ & $\begin{array}{l}\text { Garantir que o cadastro de embarque } \\
\text { seja feito dentro do prazo para } \\
\text { atracaçẫo do navio. }\end{array}$ & Mina & $\begin{array}{l}\text { [(número de navios com IE recebida } 72 \mathrm{~h} \\
\text { antes de sua atracaçăo) / (número de } \\
\text { navios atracados)] } \times 100\end{array}$ & $\%$ & $>$ & $8,33 \%$ & Fonte: CADEX & Semanal & Mina \\
\hline $\begin{array}{l}\text { Aderência ao volume da } \\
\text { PV (previsẫo de vendas) } \\
\text { em mercado externo por } \\
\text { produto. }\end{array}$ & $\begin{array}{l}\text { Garantir máxima assertividade na } \\
\text { previsão de vendas (PV) e otimização } \\
\text { de estoques. }\end{array}$ & Mina & $\begin{array}{l}\text { Aderência ao volume da } \mathrm{PV}=\text { volume } \\
\text { total por produto realizado / volume por } \\
\text { produto informado mina }\end{array}$ & $\%$ & $>$ & $8,33 \%$ & $\begin{array}{l}\text { Orç: Planejado: FAP 2009- } \\
\text { Orçamento } \\
\text { Prog: RPM } \\
\text { Real: SGOP }\end{array}$ & Mensal & Mina \\
\hline Ciclo Total & $\begin{array}{l}\text { Medir o ciclo total dos vagöes } \\
\text { destinados ao transporte de Mfe do } \\
\text { sistema sul }\end{array}$ & Ferrovia & $\begin{array}{l}\text { Tempo em horas entre partidas } \\
\text { subsequentes }\end{array}$ & $\mathrm{h}$ & $<$ & $8,33 \%$ & $\begin{array}{l}\text { Planilha de tempos da } \\
\text { ferrovia validada na reuniăo } \\
\text { de } 8 \text { h40 com as interfaces } \\
\text { do sistema sul. }\end{array}$ & Semanal & PPC \\
\hline $\begin{array}{l}\text { Aderência da chegada } \\
\text { dos trens nos Portos Sul }\end{array}$ & $\begin{array}{l}\text { Garantir a chegada conforme } \\
\text { programaçăo informada pela ferrovia }\end{array}$ & Ferrovia & $\begin{array}{l}\text { 1) Se chegadareal }<=\text { chegada prevista }+ \\
\text { 15 min entẫo OK; (tolerância) } \\
\text { 2) Se chegada real > chegada prevista }+ \\
15 \text { min, entẫo NOK; } \\
\text { Aderência = Numero OKs / Numero trens }\end{array}$ & $\%$ & $>$ & $8,33 \%$ & $\begin{array}{l}\text { Planilha da ferrovia com } \\
\text { previsẫo de chegada de } \\
\text { trens }\end{array}$ & Semanal & PPC \\
\hline $\begin{array}{l}\text { Aderência da oferta para } \\
\text { carga à programaçẫo } D+ \\
30 \text { da oferta }\end{array}$ & $\begin{array}{l}\text { Garantir a programação de trens para } \\
\text { mina }\end{array}$ & Ferrovia & $\begin{array}{l}\text { Dispersäo }=\text { (média lotes ofertados / } \\
\text { média programa } D+30)\end{array}$ & $\%$ & $>$ & $8,33 \%$ & Ata de reuniẫo diária & Semanal & PPC \\
\hline $\begin{array}{l}\text { Aderência da oferta para } \\
\text { descarga à programaçäo } \\
D+30 \text { da oferta }\end{array}$ & $\begin{array}{l}\text { Garantir a programação de trens para } \\
\text { porto }\end{array}$ & Ferrovia & $\begin{array}{l}\text { Dispersão }=(\text { média lotes ofertados / } \\
\text { média programa } D+30)\end{array}$ & $\%$ & $>$ & $8,33 \%$ & $\begin{array}{l}\text { Atas de reunião (planilha } \\
\text { da reuniäo } 11 \mathrm{~h} \text { ) }\end{array}$ & Semanal & PPC \\
\hline $\begin{array}{l}\text { Volume embarcado para } \\
\text { os clientes }\end{array}$ & $\begin{array}{l}\text { Medir o volume total de minério de } \\
\text { ferro embarcado }\end{array}$ & Porto & Volume Embarcado de minério de ferro & Mton & $>$ & $8,33 \%$ & SGOP & Semanal & Porto \\
\hline $\begin{array}{l}\text { Cumprimento do programa } \\
\mathrm{D}+30 \text { da descarga }\end{array}$ & $\begin{array}{l}\text { Medir a aderência da descarga de } \\
\text { MFe no porto conforme programaçẫo } \\
\text { D+30 }\end{array}$ & Porto & $\begin{array}{l}\text { Aderência = Média de Lotes } \\
\text { descarregados / Média de Lotes prog } \\
D+30 \text { para descarga }\end{array}$ & $\%$ & $>$ & $8,33 \%$ & $\begin{array}{l}\text { Planilha RD (ata reuniâo } \\
\text { diária), planilha } \mathrm{D}+30\end{array}$ & Semanal & Porto \\
\hline OEE Descarga & $\begin{array}{l}\text { Avaliar a eficiência global dos } \\
\text { equipamento, rotas ou do sistema } \\
\text { geral de descarga }\end{array}$ & Porto & $O E E=D F X U T X P R O D$ & $\%$ & $>$ & $8,33 \%$ & Planilha da OEE (SGOP) & Semanal & Porto \\
\hline $\begin{array}{l}\text { Aderência da taxa } \\
\text { comercial de embarque } \\
\text { dos navios }\end{array}$ & $\begin{array}{l}\text { Medir a performance global de um } \\
\text { navio, equipamento, linha, berço ou } \\
\text { porto }\end{array}$ & Porto & $\begin{array}{l}\text { Cálculo : Taxa Com=CMTOD, onde } \\
\text { CM= carga movimentada e TOD =é o } \\
\text { número total de horas corridas em que o } \\
\text { navio permanece atracado no terminal, } \\
\text { iniciando-se a partir do momento em que } \\
\text { é feita a atracaçấo do navio e terminando } \\
\text { com a desatracaçấo do mesmo. }\end{array}$ & $\%$ & $>$ & $8,33 \%$ & $\begin{array}{l}\text { Orçamento } \\
\text { Programa } \\
\text { Real: SGOP (planilha } \\
\text { VOKT) }\end{array}$ & Semanal & Porto \\
\hline
\end{tabular}

Tabela 11 - Descrição detalhada dos indicadores de desempenho 


\subsection{Resultados Alcançados no FNS Versus Recompensa}

A partir do preenchimento de todos os resultados do mês pelo responsável do indicador é realizada a importação dos dados para o FNS. Finalmente o sistema avalia o resultado do mês do indicador versus o esperado, assim a partir daí os indicadores assumem um código de cores para permitir a rápida identificação de objetivos abaixo da expectativa. Sendo assim a cor verde identifica que o mesmo está dentro dos resultados esperados, a cor amarela identifica que o resultado está abaixo porém dentro da faixa de tolerância, e finalmente o vermelho significa que o resultado está abaixo da expectativa e da faixa de tolerância.

Conforme a proposição de Kaplan \& Norton (1997) apresentada na revisão bibliográfica de vincular medidas de desempenho a recompensas, optou-se por vincular os resultados alcançados pelas áreas no sistema de indicadores de desempenho com a remuneração variável da participação nos resultados.

- Foi realizado o desdobramento até o nível operacional, garantindo que todos os empregados possuíssem metas individuais;

- As metas foram desdobradas de forma que os resultados dos níveis inferiores suportem os resultados dos níveis superiores, ou seja, as metas do empregado do nível operacional têm que ajudar no alcance das metas dos supervisores e gerentes. As metas dos supervisores e gerentes, por sua vez, têm que ajudar no alcance das metas do gerente geral e assim, sucessivamente. Desta forma, todos cooperam no alcance das metas da diretoria e nos resultados da empresa;

- As metas foram alinhadas entre funções equivalentes, garantindo o alinhamento vertical e horizontal. 
A disciplina na medição dos indicadores e acompanhamento para correção de desvios permitiu a geração de resultados que ainda não tinham sido alcançados pelo departamento de logística, especialmente em 2009 quando o mercado passava por um momento de retomada de crise e os empregados obtiveram a maior média de todos os tempos de remuneração variável, baseada nos resultados dos indicadores, mas não podemos deixar de pontuar que a maior base para o sucesso é a disciplina no acompanhamento. 


\section{CAPÍTULO 5 - CONCLUSÕES E SUGESTÕES PARA TRABALHOS FUTUROS}

\subsection{Conclusões}

O objetivo principal desta dissertação foi propor um modelo para implantação de um sistema de indicadores de desempenho. Para atender este objetivo foi necessário o atendimento de três objetivos secundários.

O primeiro objetivo secundário de identificar os principais modelos de gestão baseados em indicadores de desempenho foi contemplado visto que, foram avaliados 6 modelos de gestão de desempenho de autores renomados e validados em livros, artigos nacionais e internacionais, teses de doutorado e dissertações de mestrado constantes na revisão bibliográfica.

O segundo objetivo secundário dentre os modelos de gestão abordados: propor um modelo para implantação de sistema de indicadores de desempenho foi contemplado visto que, a partir do trabalho de revisão bibliográfica foi proposto no Capítulo 3 um método de implantação de um sistema de indicadores. O terceiro objetivo secundário foi atendido através da aplicação do sistema de indicadores em uma empresa de mineração, no departamento de logística, gerando como resultado o farol de nível de serviço com 12 indicadores operacionais importantes para o alcance dos objetivos do departamento. Ainda na aplicação destaca-se a inclusão de duas novas perspectivas no BSC para completar a implantação no departamento de logística.

As reuniões da alta administração foram importantes na medida em que houve envolvimento de toda a gerência criando-se maior comprometimento na realização dos objetivos estratégicos da diretoria e também porque o envolvimento da gerência no desdobramento dos objetivos da diretoria executiva para a diretoria de operações logísticas subsidiou o próximo passo que é o desdobramento dos objetivos da diretoria para as gerências. 
A etapa de identificação dos pontos fortes e pontos fracos mostraram-se especialmente importante para a implementação do sistema de indicadores de desempenho. A equipe do departamento, ao reunir-se para eleger os seus pontos fortes e pontos fracos, submeteu-se a uma reflexão profunda dos seus processos de trabalho e de seu desempenho. Ainda, a equipe adquiriu uma base sólida para a identificação de suas iniciativas estratégicas.

Percebeu-se que ao discutir as iniciativas estratégicas do departamento, a equipe envolvida na atividade acabou levantando questões de grande relevância. Por exemplo, pelo fato de funcionários de diferentes áreas do departamento de logística terem observado de forma interdisciplinar os problemas do departamento como um todo. Os mesmos acabaram por perceber necessidades, ora comuns entre áreas, ora bastante discrepantes, por decorrência das diferentes visões de processo existentes no mesmo departamento.

Percebeu-se que o maior benefício oferecido por esta etapa, foi à percepção do quanto os objetivos gerenciais do departamento estavam alinhados ao que era esperado deste, pela alta gerência.

Nota-se que ao estabelecer os indicadores estratégicos percebeu-se que, apesar de terem sido estabelecidos um número relativamente alto de indicadores operacionais, estes acabaram reduzindo-se a um número relativamente pequeno para os objetivos estratégicos.

Uma avaliação mais aprofundada do método requereria um tempo maior de apreciação dos resultados obtidos com o modelo, bem como, a aplicação em outras empresas ou departamentos da mesma área, ou não, de atuação, bem como na área acadêmica.

Por fim, vale observar que o modelo proposto foi estruturado de modo a ter sua aplicação rápida e eficiente estimulada pelo bom relacionamento interdepartamental 
fazendo com que as pessoas de diferentes níveis e áreas convivam em constante interação. A busca pela excelência na operacionalização dos processos com o uso dos indicadores de desempenho irá, portanto, não só atender a uma determinada necessidade premente da organização, definida por uma estratégia de ação, como também em paralelo, aprimorar o clima organizacional, sendo este, portanto, outro importante "papel" dos indicadores de desempenho.

\subsection{Sugestões para Trabalhos Futuros}

Novas alternativas de estudo podem ser realizadas a partir desta dissertação de mestrado, como segue:

Avaliar os resultados alcançados a partir de novas aplicações do modelo proposto para implantação de um sistema de indicadores de desempenho, em outros departamentos e empresas da mesma área de atuação, ou não, efetuando as correções de rumo que por ventura se façam necessárias.

Desenvolver trabalho com aplicação no âmbito acadêmico. 


\section{REFERÊNCIAS BIBLIOGRÁFICAS}

AKAO, Y. Desdobramento das diretrizes para o sucesso do TQM. Porto Alegre: Bookman, 1997.

ALBRECHT, Karl. Revolução nos serviços: como as empresas podem revolucionar a maneira de tratar os seus clientes. São Paulo: Pioneira, 1992.

ALBRECHT, Karl. A única coisa que importa: trazendo o cliente para dentro da sua empresa. São Paulo: Pioneira, 1995.

ARVIS , J-F et al. Connecting to Compete: Trade Logistics in the Global Economy, The Global Enabling Trade Report, World Economic Forum, 2008.

ARVIS, J-F., RABALLAND, G. Marteau, J-F. The Cost of Being Landlocked: Logistics Costs and Supply Chain Reliability, The World Bank, World Bank Policy Research Working Paper 4258, June 2007.

ATKINSON, Anthony. Strategic performance measurement and incentive compensation. European Management Journal, v.16, n. 5, p.552-561,1998.

ATKINSON, P. Strategy: failing to plan is planning to fail. Institute of management services, Management services, Jan. 2004.

ARVESON, Paul. The Balanced Scorecard and Knowledge Management. Balanced Scorecard Institute, 2002.

BALANCED. Balanced Scorecard model for managers, Nation, The (Thailand), Jan. 2004.

BEECROFT, G. D. The role of quality in strategic management. Canada: Institute for Improvement in Quality and Productivity (IIQP), University of Waterloo, 1999. 
BIRKNER, L. R.; BIRKNER, R. K. Knowledge Capital Measures and EH\&S. USA: Occupational Hazards; Vol. 62, Issue 8, p49 Aug. 2000.

BITITCI, U. S.; SUWIGNJO, P.; CARRIE, A. S. Strategy management through quantitative modeling of performance measurement systems. International Journal of Production Economics, v. 69, p. 15-22, 2001.

BONTIS, N.; DRAGONETTI, N. C.; JACOBSEN, K.; ROOS, G. The Knowledge Toolbox: A Review of the Tools Available to Measure and Manage Intangible Resources. European Management Journal, Great Britain Vol. 17, No. 4, pp. 391-402, 1999.

BOWERSOX, Donald J.; CLOSS, David. Logística Empresarial. São Paulo: Atlas, 2001.

BUKOWITZ, W. R. Visualizing, Measuring and Managing Knowledge. Research Technology Management; Jul/Aug97, Vol. 40 Issue 4, p24.

BUSH, P.; BARROWS, E. Strategy Maps for Government Organizations. Balanced Scorecard Collaborative, Inc., 2004.

CAMERON, P. The balancing act. CMA Management, Feb 2002.

CAMPOS, Vicente Falconi. O Verdadeiro Poder. Nova Lima: INDG Tecnologia e Serviços Ltda, 2009.

CAMPOS, Vicente Falconi. Gerenciamento da Rotina do Trabalho do Dia-a-Dia. Belo Horizonte: Desenvolvimento Gerencial, 2002.

CAMPOS, V. F. Gerenciamento pelas diretrizes. Belo Horizonte: Fundação Christiano Ottoni, 1996. 
CLARKE, P.;TYLER, F. Implementing a Balanced Scorecard: An Irish Example Department of Accountancy, University of College Dublin, 2001.

DORNIER, P. P.; ERNEST, R.; FENDER, M.; KOUVELIS, P. Logística e Operações Globais. Texto e Casos. São Paulo: Atlas, 2000.

EPSTEIN, Marc; MANZONI, Jean-François. Implementing corporate strategy: from tableaux the bord to balanced scorecard. European Management Journal, v. 16, n.2, April 1998.

FRANGOS, C. A. Aligning learning with strategy. Mediatec Publishing, Inc. Chief learning officer, Mar. 2004.

FITZSIMMONS, James A. e FITZSIMMONS, Mona J. Administração de serviços: operações, estratégias e tecnologia de informação. Porto Alegre: Bookman, 2000.

FRIGA, Paul N. The McKinsey engagement; a powerful toolkit for more efficient \& effective team problem solving. New York: McGraw Hill, 2009.

FRIGO, M. L. Strategy and execution a continual process. Institute of management accounts, Strategic Finance, Apr. 2004.

GASPARETTO, Valdirene. Proposta de uma sistemática para avaliação de desempenho em cadeias de suprimentos. Florianópolis: UFSC, 2003. Tese (Doutorado em Engenharia de Produção) - Programa de Pós Graduação em Engenharia de Produção, Universidade Federal de Santa Catarina, Florianópolis.

GIL, Antônio Carlos. Como elaborar projetos de pesquisa. São Paulo: Atlas, 1993.

GOODERHAM, G. Power tool. Toronto, Ontario, Canada, CMA Magazine; Vol. 72 Issue 7, p11; Sep98. 
HANSEN, P. B. Indicadores de desempenho e gerenciamento de processos. Porto Alegre: Apostila do curso de mestrado profissional em engenharia de produção,PPGEP, UFRGS, 1996.

HARRINGTON, J. H. The new model for improvement: Total improvement management:organization need a clear plan that merges the many improvement methodologies. Management decision Vol. 33 No. 3, 1995 pp. 17-24 originalmente publicado em Business Process Re-engineering \& Management Journal, Vol.1, 1995, pp.31-43.

HESKETT, J. L.; JONES, T. O.; LOVEMANN, G. W.; SASSER W. E.; SCHLESINGER L. A. Putting the service-profit chain to work. Harvard Business Review, Mar/Apr. 1994.

HRONEC, S. M. Sinais Vitais: usando medidas de desempenho da qualidade, tempo e custos para traçar a rota para o futuro de sua empresa. São Paulo: Makron Books, 1994 .

JOHNSON, H. Thomas; KAPLAN, Robert S. Contabilidade gerencial: a restauração da relevância da contabilidade nas empresas. Tradução: Ivo Korytowski. Rio de Janeiro: Campus, 1993.

KAPLAN, R.; NORTON, D. "The Balanced Scorecard". The School Administrator, Fevereiro 2010.

KAPLAN, R.; NORTON, D. Execution Premium: Linking Strategy to Operations for Competitive Advantage. Harvard Business School Press, 2008.

KAPLAN, Robert S.; NORTON, David P. Mapas estratégicos: convertendo ativos intangíveis em resultados tangíveis. Rio de Janeiro: Campus, 2004. 
KAPLAN, R.; NORTON, D. Strategic Maps: Converting intangible assets into tangible outcomes. Harvard Business School Press, Feb 2004.

KAPLAN, R.; NORTON, D. Measuring the strategic readiness of intangible assets. Harvard Business Review, Feb 2004.

KAPLAN, R.; NORTON, D. How strategy maps frame an organization's objectives. Financial executive, Mar/Apr 2004.

KAPLAN, R. Robert Kaplan mede o "valor intangível" da TI. São Paulo: Computerworld/EUA. 28 de Abril de 2004.

KAPLAN, Robert S.; NORTON, David P. Organização orientada para a estratégia. Rio de Janeiro: Campus, 2001.

KAPLAN, R.; NORTON, D. Organização orientada para a estratégia: como as empresas que adotam o Balanced Scorecard prosperam no novo ambiente de negócios. Rio de Janeiro: Campus, 2001.

KAPLAN, R.; NORTON, D. Organização orientada para a estratégia. Rio de Janeiro: Campus, 2000.

KAPLAN, R.; NORTON, D. Having trouble with your strategy? Then Map it. Harvard Business Review, Sep/Oct 2000.

KAPLAN, R.; NORTON, D. A estratégia em ação: Balanced Scorecard. Rio de Janeiro: Campus, 12 ed., 1997.

KAPLAN, R.; NORTON, D. Using the Balanced Scorecard as a strategic management system. Harvard Business Review, Jan/ Feb 1996. 
KAPLAN, R.; NORTON, D. Linking the Balanced Scorecard to strategy. California Management Review, vol. 39, no. 1, Fall 1996.

KAPLAN, R.; NORTON, D. Puting the Balanced Scorecard to work. Harvard Business Review, v.71, n.5, Sept/Oct. 1993.

KAPLAN, R.; NORTON, D. The Balanced Scorecard - measures that drive performance. Harvard Business Review, v.70, n.1, Jan/Feb. 1992.

LAMBERT, Douglas M. STOCK, James R. VANTINE, José G. Administração estratégica da logística. São Paulo: Vantine Consultoria, 1998.

LANE, Bill. Jacked Up; the inside story of how Jack Welck talked GE into becoming the world's greatest company. New York: McGraw Hill, 2008.

LEE S.F.;KO A.S.O. Building balanced scorecard with SWOT analysis, and implementing "Sun Tzu's The Art of Business Management Strategies" on QFD methodology. Managerial Auditing Journal. MCB University Press- ISSN- 0268-6902Jan/ Feb 2000.

MEMEDOVIC, Olga et al. Fuelling the global value chains: what role for logistics capabilities?. International J. Technological Learning, Innovation and Development, Vol. 1, No. 3, 2008.

MINAYO, Maria Cecília de et al. Pesquisa social: teoria, método e criatividade. Petrópolis: Vozes, 2001.

MINTZBERG. Henry. A criação artesanal de estratégia. In: Coleção Harvard de Administração. Jul./ago., 1987. 
MINTZBERG, Henry et al. Safári de estratégia: um roteiro pela selva do planejamento estratégico. Porto Alegre: Bookman, 2000.

MOREIRA, Daniel Augusto. Dimensões do Desempenho em Manufatura e Serviços. São Paulo: Pioneira, 1996.

MULLER, C.J.; Modelo de Gestão Integrando Planejamento Estratégico, Sistemas de Avaliação de Desempenho e Gerenciamento de Processos (MEIO - Modelo de Estratégia, Indicadores e Operações). Tese de doutorado. Porto Alegre. UFRGS. Dez 2003.

NEELY, Andy; GREGORY, Mike; PLATTS, Ken. Performance measurement system design: A literature review and research agend. International Journal of Operations \& Production Management, v.15, n. 4, p. 80-116, 1995.

NORMANN, Richard. Administração de serviços: estratégia e liderança na empresa de serviços. São Paulo: Atlas, 1993.

OLVE, N.;ROY J.;WETTER M. Condutores da performance: um guia prático para o uso do Balanced Scorecard. Rio de Janeiro:Qualitymark Ed., 2001.

RECH A.R. Avaliando a gestão dos correios na Bahia através de indicadores de desempenho. Universidade Federal do Rio Grande do Sul.Porto Alegre, Dez, 2002, Dissertação de mestrado.

RECORD. Record Q1 business at skandia. Money Marketing. May, 2004.

REDI, R. Entendendo as características do Balanced Scorecard (BSC) e do Gerenciamento pelas diretrizes (GDP). São Paulo: Symnetics Business Transformation, 2003. 
REDI, R. Modelo de Gestão da Implementação da Estratégia através do Uso Integrado do Balanced Scorecard e do Gerenciamento pelas Diretrizes. Dissertação de Mestrado em Engenharia de Produção - Universidade Federal do Rio Grande do Sul, Rio Grande do Sul, 2003.

RIBEIRO, J. L e CATEN, C. S. e FRITSCH, C. Controle Integrado de Processos. Revista Produto e Produção, vol. 2, n 3, p. 160-175. Programa de Pós-graduação em Engenharia de Produção, Escola de Engenharia -UFRGS, outubro 1998.

RIGBY, D. Management tools survey 2003;usage up as companies strive to make headway in tough times. Strategy \& Leadership. Vol. 31 N.5, 2003.

ROHM, Howard. Using the Balanced Scorecard to Align Your Organization. Balanced Scorecard Institute, january 2008.

RUMMLER, G. A.; BRACHE, A. P. Melhores desempenhos das empresas. São Paulo: Macron Books, 1994.

RUMMLER, G. A. Serious performance consulting; according to rummler. OR, USA: John Wiley \& Sons, 2007.

SHIH-JEN K.H.;McKAY R.B. Balanced Scorecard: two perspectives. CPA journal; mar 2002, Vol. 72 issue 3, pg 20, 6p.

SILVA, A. Estabelecendo indicadores de desempenho para uma organização pública: uma abordagem segundo os preceitos do "Balanced Scorecard". Porto Alegre: PPGEP/UFRGS, 2002. Dissertação de Mestrado de Engenharia de Produção.

SILVA, Edna Lúcia da.; MENEZES, Estera Muszkat. Metodologia da pesquisa e elaboração da dissertação. Florianópolis: UFSC/PPGEP/LED, 2000. 
SIM, K. L.;KOH, H.C. Balanced scorecard: A rising trend in strategic performance measurement, Measuring Business Excellence, 2001.

SIMON, Croom; SAM, Barani; Dan, Belanger; TIM, Lyons; JAIME, Murakami. Sustainable supply chain management - an exploration of current practice, Supply Chain Management Institute, University of San Diego, Alcala Park, San Diego, USA, 2009.

SINK, D. S.; TUTTLE, T. C. Planejamento e medição para a performance. Rio de Janeiro: Qualitymark, 1993.

SINK, S. D.; SMITH G. L. Reclaiming Process Measurement build a more effective measurement system. IEE solutions, Feb. 1999.

SINK, S. D.; TUTTLE, T. C. The performance management question in the organization of the future. IM , Jan/Feb 1990.

SOBEK, D. K. et. al. Understanding A3 thinking; a critical component of Toyota's PDCA management system. Boca Raton, Florida: CRC Press, 2008.

SVEIBY, K. E. A nova riqueza das organizações: gerenciando e avaliando patrimônios de conhecimento. $2^{\underline{a}}$ ed. Rio de Janeiro: Campus, 1998.

TAKASHINA, N. T., FLORES, M. C. X. Indicadores da Qualidade e do Desempenho. Rio de Janeiro: Qualitymark Editora Ltda, 1997. 100p. ISBN 85-7503-075-5.

TENNANT, C.; ROBERTS, P. A. B.; Hoshin Kanri: a technique for strategic quality management. Quality Assurance, 8: 77-90, 2000.

THIOLLENT, M. Metodologia da Pesquisa-ação. 8.ed. São Paulo: Cortez, 1988. 
WESTON, J. B. Doing better business. American nurseryman, Dec. 2003.

WEXIA, Cheng. Measuring Performance of Transportation Carriers. Massachusetts Institute of Technology, Jun. 2009.

Wikipedia. The Free Enciclopédia. Disponível em: http://en.wikipedia.org/wiki/Model. Acesso em 2010.

WITCHER, J. B.; BUTTERWORTH, R. Hoshin Kanri: Police Management in Japaneseowned UK subsidiaries. Journal of Management Studies 38:5 University of East Anglia, UK, 2001.

WOOD, G. R.; MUNSHI, K. F. Hoshin Kanri: a systematic approach to breakthrough improvement. Total Quality Management, Vol. 2 Issue 3, p213, May 1991. 